OPEN ACCESS

Edited by:

Sandip D. Kamath,

James Cook University, Australia

Reviewed by:

Michael D. Kulis,

University of North Carolina at

Chapel Hill, United States

Blanca Cárdaba,

Health Research Institute Foundation

Jimenez Diaz (IIS-FJD), Spain

${ }^{*}$ Correspondence:

Rudolf Valenta

Rudolf.valenta@meduniwien.ac.at

Specialty section:

This article was submitted to Vaccines and Molecular Therapeutics, a section of the journal

Frontiers in Immunology

Received: 16 July 2021

Accepted: 23 August 2021 Published: 23 September 2021

Citation:

Fuhrmann V, Huang H-J, Akarsu A,

Shilovskiy I, Elisyutina O, Khaitov $M$, van Hage M, Linhart B, Focke-Tejkl M, Valenta $R$ and Sekerel BE (2021) From

Allergen Molecules to Molecular Immunotherapy of Nut

Allergy: A Hard Nut to Crack.

Front. Immunol. 12:742732. doi: 10.3389/fimmu.2021.742732

\section{From Allergen Molecules to Molecular Immunotherapy of Nut Allergy: A Hard Nut to Crack}

\author{
Verena Fuhrmann ${ }^{1}$, Huey-Jy Huang ${ }^{1}$, Aysegul Akarsu ${ }^{2}$, Igor Shilovskiy ${ }^{3}$, Olga Elisyutina ${ }^{3}$, \\ Musa Khaitov ${ }^{3,4}$, Marianne van Hage ${ }^{5}$, Birgit Linhart ${ }^{1}$, Margarete Focke-Tejkl ${ }^{1,6}$, \\ Rudolf Valenta ${ }^{1,3,6,7^{*}}$ and Bulent Enis Sekerel ${ }^{2}$ \\ 1 Division of Immunopathology, Department of Pathophysiology and Allergy Research, Center for Pathophysiology, \\ Infectiology and Immunology, Medical University of Vienna, Vienna, Austria, ${ }^{2}$ Division of Allergy and Asthma, Department of \\ Pediatrics, Hacettepe University Faculty of Medicine, Ankara, Turkey, ${ }^{3}$ Laboratory for Molecular Allergology, National \\ Research Center (NRC) Institute of Immunology Federal Medical-Biological Agency (FMBA) of Russia, Moscow, Russia, \\ ${ }^{4}$ Pirogov Russian National Research Medical University, Moscow, Russia, ${ }^{5}$ Department of Medicine Solna, Division of \\ Immunology and Allergy, Karolinska Institutet and Karolinska University, Hospital, Stockholm, Sweden, ${ }^{6}$ Karl Landsteiner \\ University of Health Sciences, Krems, Austria, ${ }^{7}$ Laboratory of Immunopathology, Department of Clinical Immunology and \\ Allergology, Sechenov First Moscow State Medical University, Moscow, Russia
}

Peanuts and tree nuts are two of the most common elicitors of immunoglobulin $E$ ( $(\mathrm{gE} E$ )mediated food allergy. Nut allergy is frequently associated with systemic reactions and can lead to potentially life-threatening respiratory and circulatory symptoms. Furthermore, nut allergy usually persists throughout life. Whether sensitized patients exhibit severe and lifethreatening reactions (e.g., anaphylaxis), mild and/or local reactions (e.g., pollen-food allergy syndrome) or no relevant symptoms depends much on IgE recognition of digestion-resistant class I food allergens, IgE cross-reactivity of class II food allergens with respiratory allergens and clinically not relevant plant-derived carbohydrate epitopes, respectively. Accordingly, molecular allergy diagnosis based on the measurement of allergen-specific IgE levels to allergen molecules provides important information in addition to provocation testing in the diagnosis of food allergy. Molecular allergy diagnosis helps identifying the genuinely sensitizing nuts, it determines IgE sensitization to class I and II food allergen molecules and hence provides a basis for personalized forms of treatment such as precise prescription of diet and allergen-specific immunotherapy (AIT). Currently available forms of nut-specific AIT are based only on allergen extracts, have been mainly developed for peanut but not for other nuts and, unlike AIT for respiratory allergies which utilize often subcutaneous administration, are given preferentially by the oral route. Here we review prevalence of allergy to peanut and tree nuts in different populations of the world, summarize knowledge regarding the involved nut allergen molecules and current AIT approaches for nut allergy. We argue that nut-specific AIT may benefit from molecular subcutaneous AIT (SCIT) approaches but identify also possible hurdles for such an approach and explain why molecular SCIT may be a hard nut to crack.

Keywords: allergen molecules, component, food allergy, immunotherapy, molecular allergy diagnosis, peanut, tree nut 


\section{INTRODUCTION}

Nuts are nutrient-dense foods that receive increasing attention due to reports regarding their possible health-promoting properties and their pleasant taste $(1,2)$. At the same time, tree nuts and peanuts are among the most common elicitors of anaphylaxis, a severe, potentially life-threatening hypersensitivity reaction mediated by allergen-specific IgE antibody-induced mast cell and basophil activation (3-6). The possibility of accidental nut ingestion and the associated fear of experiencing severe allergic reactions is particularly challenging for nut-allergic children and their parents and results in a considerable reduction in quality of life (7-10).

In allergology, a distinction is made between tree nuts and peanuts by defining a nut according to what is considered a nut in the culinary sense and less according to the botanical definition. Generally, "real" botanical nuts like the hazelnut, but also several seeds and drupes that grow on trees are considered tree nuts. Peanuts, which grow underground, are classified as legumes (11). Walnut, pistachio, pecan, hazelnut, almond, cashew, Brazil nut and macadamia are responsible for most allergic reactions to tree nuts and therefore included in this review under the umbrella of "tree nuts" (11) and the term "nut" used herein generally refers to peanuts and tree nuts unless otherwise specified.

True food allergy (class I) is characterized by the primary sensitization to the allergy-causing food via the gastrointestinal tract $(12,13)$ (Figure 1). Therefore, class I food allergens have usually higher stability to gastric digestion than other allergens (14). Immediate allergic reactions to nuts in sensitized patients occur within minutes after nut ingestion. It has been also speculated that $\operatorname{IgE}$ sensitization to class I food allergens may occur by epicutaneous sensitization (15) but on the other hand it was found that epicutaneous allergen application does not induce or boost allergen-specific IgE responses (16).

The severity of the allergic reaction depends on the amount of allergen to which the patient is exposed and on other factors such as barrier function and allergen-specific sensitivity which often is associated with specific IgE levels. Class I food allergens often contain sequential IgE epitopes in addition to conformational IgE epitopes which indicates that sensitization occurs also to allergen fragments emerging through digestion in the gastrointestinal tract (17-19). Allergic reactions to nuts are typically IgE-mediated (type I reactions) and might cause symptoms affecting the gastrointestinal tract (abdominal pain, vomiting), the skin (urticaria, angioedema), the respiratory tract (rhino-conjunctivitis, wheezing) and, in severe cases, the cardiovascular system (loss of consciousness, low blood pressure) (Figure 1). Anaphylactic shock characterized by drop

\footnotetext{
Abbreviations: Ig, Immunoglobulin; AIT, Allergen-specific immunotherapy; SCIT, Subcutaneous immunotherapy; PFAS, Pollen-food allergy syndrome; SPT, Skin prick test; DBPCFC, Double-blind placebo-controlled food challenges; LDC, Lip dose challenge; BAT, Basophil activation test; CCD, Cross-reactive carbohydrate determinant; PR-10, Pathogenesis-related class 10; nsLTP, Nonspecific lipid transfer protein; OFC, Oral food challenge; APT, Atopy patch test; CRD, Component resolved diagnostics; SLIT, Sublingual immunotherapy; OIT, Oral immunotherapy; EPIT, Epicutaneous immunotherapy.
}

in blood pressure and cardiovascular failure involves several organ systems and requires immediate treatment with epinephrine (20). Several factors such as mast cell activation and/or load, existing co-allergies or asthma might enhance the risk of anaphylactic reactions to tree nuts (21).

Class II food allergy is associated with sensitization to pollen allergens. Patients are usually first sensitized to a pollen allergen and produce IgE antibodies which cross-react with allergens present in food. Examples include the major birch pollen allergen, Bet $\mathrm{v} 1$ and the panallergen, profilin which were discovered first in birch pollen (22-26). IgE sensitization to class II food allergens is usually associated with mild allergic reactions known as pollen-food allergy syndrome (PFAS) or oral allergy syndrome (OAS) $(20,27)$. Clinical characteristics of PFAS include mainly oropharyngeal symptoms (27). Interestingly, it has been indicated that ingestion of birch pollen-related allergens from food sources such as Cor a 1 from hazelnut, could activate allergen-specific $\mathrm{T}$ cells independent of IgE, leading to late-phase and chronic allergic inflammation and this might further cause disorders such as atopic dermatitis in sensitized patients $(28,29)$. Moreover, pollen-related nut allergens causing PFAS might be associated with eosinophilic esophagitis, although they seem to be of less relevance than homologues from fruits and vegetables (30). However, eosinophilic esophagitis can be caused also by class I food allergens from milk, egg and wheat, while peanut and tree nuts seem to be of minor relevance (31). Major features of class II food allergens are that they contain mainly conformational but not sequential IgE epitopes which are sensitive to digestion and heating (32-34). The sensitization to class II food allergens is initially caused by pollen allergens and results in IgE and $\mathrm{T}$ cell cross-reactivity with the related food allergens $(35,36)$. IgE sensitization to class II food allergens is highly prevalent in countries with high exposure to the crossreactive pollen allergens $(37,38)$. Accordingly, diagnostics including the measurement of IgE against the originally sensitizing pollen allergens (39) and allergen-specific immunotherapy to the cross-reactive pollen allergens can improve not only pollen allergy but also the associated food allergy to some extent $(40,41)$.

Diagnosis of nut allergy usually starts with a thorough evaluation of the patient's history. Allergic sensitization can be detected by skin prick tests (SPT) and in vitro diagnostics with allergen extracts. However, sensitization determined by measurement of specific IgE antibodies and SPT does not always indicate clinical food allergy, which can only be confirmed by the occurrence of specific allergic symptoms after food exposure. Double-blind placebo-controlled food challenges (DBPCFC) are still considered the "gold standard" of food allergy testing, although patients are at risk of anaphylaxis during the procedure $(42,43)$. Lip dose challenge (LDC) is another possibility of testing which has a good predictive value for nut allergy (44). However, in recent years, molecular diagnosis with defined and mainly recombinant allergens by IgE serology has turned out to be very helpful in diagnosing nut allergy, in particular when it is combined with a thorough medical history (45). Another key problem in therapy of nut allergy is 

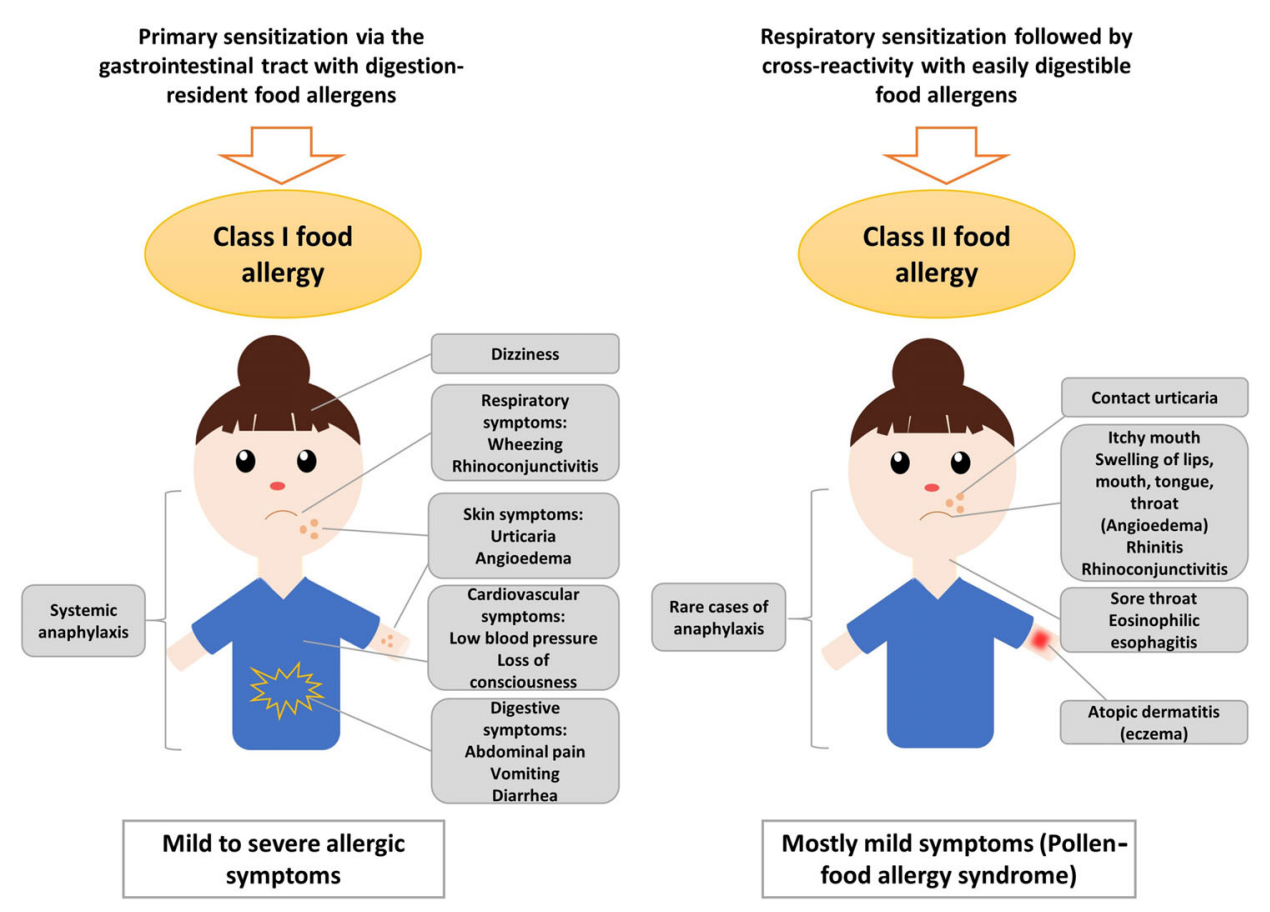

FIGURE 1 | Sensitization to class I and class || nut allergens is associated with different clinical symptoms. Sensitization to class II nut allergens usually occurs by respiratory sensitization to cross-reactive respiratory allergens (e.g., pollen allergens) and is associated with mild symptoms such as oral allergy syndrome, local reactions in the oropharynx, esophagus and may trigger atopic dermatitis and/or urticaria. Sensitization to class I digestion-resistant nut allergens usually occurs via the gastrointestinal tract and eventually via the skin and is associated with systemic and severe manifestations such as anaphylaxis but also mild symptoms are possible.

the lack of modern and effective allergen-specific treatment options. At present, avoidance of the disease-causing allergens is a possible option but there is also evidence that early introduction of for example of peanuts in the diet of sensitized but not yet symptomatic children may have beneficial effects (46). Accordingly, there are different opinions whether avoidance or rather intake should be recommended for sensitized children. Another major problem is that there is currently little progress regarding the development of modern molecular immunotherapy forms for nut allergy. Hypoallergenic allergen derivatives have been described (47) but no clinical studies have been performed so far. Sensitization to different nut allergens varies in different parts of the world due to dietary habits in diverse populations and varying allergen exposure in different areas but this is undergoing changes due to globalization and migration.

\section{IMPORTANCE OF VARIOUS NUTS AS ALLERGEN SOURCES IN DIFFERENT PARTS OF THE WORLD}

The prevalence of nut allergies among children and adults has been investigated in several studies $(11,48-51)$. However, there are large variations regarding methodology and study design which make it difficult to compare the studies and to understand the true nut allergy rates. It seems that reports on nut allergy prevalence do not provide accurate information regarding actual prevalences in the different populations due to several reasons. First of all, most studies that include a representative study population are limited to self-reports and do not contain a detailed clinical evaluation of patients. Moreover, several studies do not distinguish between sensitization to class I and class II food allergens. In this context, it must be considered that allergic reactions to nuts might be due to cross-reactivity with pollen allergens and are not caused by primary nut sensitization (11). Especially in studies from Europe, hazelnut allergy prevalence might thus be overestimated and sensitization should therefore be evaluated by molecular diagnosis to clearly distinguish between birch pollen allergic patients and those with true hazelnut allergy. This applies also to several other nuts that contain cross-reactive panallergens and cross-reactive carbohydrate determinants (CCDs). For example, many subjects who were tested positive by IgE serology using peanut allergen extracts in Zimbabwe were found to be sensitized to CCDs which usually do not cause allergic reactions (52).

Table 1 provides an overview of nut allergy prevalence studies, in particular from Europe, Northern America, Asia, Australia and Africa $(38,48-50,52-84)$.

Importantly, the worldwide prevalence of nuts causing allergy correlates strongly with the nuts that are consumed in this 
TABLE 1 | Importance of peanut and different tree nuts as allergen sources in different parts of the world.

\begin{tabular}{lllll}
\hline Region & Test methodology & Subjects tested & $\begin{array}{c}\text { Allergens } \\
\text { tested }\end{array}$ & Results
\end{tabular}

Europe (11 Sera were screened for specific lgE to food countries), allergen mixes and individual foods using

USA, ImmunoCAP. Test was considered positive if slgE

Australia $\quad \geq 0.35 \mathrm{kU}_{\mathrm{A}} / \mathrm{L}$
4522 young adults (aged 2044) were tested for at least one allergen mix. 4220 were tested for all five food allergen mixes. Participants had been previously included in the "random sample" group during the second phase of the European Community Respiratory Health Survey.
Europe (8 Questionnaire followed by serum analysis. centers: Detection of IgE sensitization to groups of food Zurich, allergens and individual foods using ImmunoCAP, Madrid, which was considered positive if slgE $\geq 0.35$

Utrecht, $\quad k U_{A} / L$. Sera of subjects were tested for lgE Lodz, reactivity to specific food allergens using an Sophia, allergen microarray assay.

\section{Athens,}

Reykjavik

and

Vilnius)
Serum samples taken from in total 719 potentially-food allergic adults (aged 20-54) and 1642 controls. Up to 240 potentially foodallergic subjects per center and 240 controls, oversampling of centers with less than 240 cases (applied for all centers).
UK (Isle of Clinical peanut allergy and/or lgE sensitization of Wight) participants was determined. Sensitization to peanuts determined by a wheal size $\geq 3 \mathrm{~mm}$ in presence of negative control during SPT. Clinical allergy was confirmed by positive SPT and convincing history or positive OFC (only Cohorts B and C).
Walnut

Peanut

Hazelnut (no information

on individual allergen molecules)
Sensitization by country (\%):

Walnut: Germany (3.3), Italy (3.1), France (3.7), Belgium (2.5), USA

(2.1), Australia (2.1), Spain (3.1), Norway (0.6), Sweden (1.1), UK (0.8), Iceland (0.0), Overall (2.2, excluding birch positive 1.8) Peanut: Germany (4.2), Italy (3.6), France (3.0), Belgium (2.0), USA (9.3), Australia (3.0), Spain (1.9), Norway (0.8), Sweden (1.0), UK (1.5), Iceland (1.2), Overall (2.6, excluding birch positive 1.8) Hazelnut: Germany (14.7), Italy (7.7), France (5.0), Belgium (6.0), USA (14.9), Australia (4.1), Spain (2.6), Norway (12.8), Sweden (11.8), UK (4.9), Iceland (0.4), Overall (7.2, excluding birch positive 3.1)

Hazelnut Walnut Peanut (individual allergen molecules tested)

IgE sensitization to food allergy by center (first number: percentage of weighted lgE-sensitization prevalence; second number: percentage of weighted lgEsensitization prevalence to "true" food allergens not associated with cross-reactivity to plant pollen allergens):

Hazelnut: Zurich $(17.8,1.1)$, Madrid (6.0, 2.4), Utrecht (12.0, $0.0)$, Lodz (6.5, 0.3), Sofia (6.3, 3.0), Reykjavik (1.3, 0.7), Overall $(9.3,0.9)$

Walnut: Zurich (5.6, 0.1), Madrid $(7.7,0.4)$, Utrecht $(1.9,0.1)$, Lodz $(3.6,0.3)$, Sofia $(2.7,0.0)$,

Reykjavik (0.1, 0.0), Overall (3.0, 0.1)

Peanut: Zurich (5.0, 0.4), Madrid $(7.2,0.5)$, Utrecht $(1.6,0.1)$, Lodz $(3.1,0.0)$, Sofia $(1.8,0.0)$, Reykjavik $(0.5,0.1)$, Overall (2.7, 0.14)

Peanut allergy prevalence was assessed in three cohorts of children born on the Isle of Wight.

Cohort A: 2181 children (aged 4) born in 1989

Cohort B: 1273 children (aged 3-4) born between 1994-1996 Cohort C: 891 children (aged 3) born between 2001-2002

Number of patients included for evaluating clinical allergy:

Cohort A: 1218

Cohort B: 1273

Cohort C: 891

Number of patients tested by

SPT:

Cohort A: 981

Cohort B: 1246

Cohort C: 642
Peanut (commercial extracts)
Percentage of sensitization:

Cohort A: 1.3

Cohort B: 3.3

Cohort C: 2.0

Percentage of clinical peanut allergy diagnosis based on positive SPT and clinical history or positive OFC:

Cohort A: 0.5

Cohort B: 1.4

Cohort C: 1.2 
TABLE 1 | Continued

\begin{tabular}{ll}
\hline Region & \multicolumn{1}{c}{ Test methodology } \\
\hline UK & Families were chosen by primary questionnaire. \\
& Mothers were asked about their peanut allergy \\
& status and dietary changes regarding peanut \\
& consumption during pregnancy. \\
& Selected children underwent SPT. SPT was \\
& considered positive if wheal size $\geq 3$ mm in \\
& presence of negative control and wheal size of at \\
least 3 mm to histamine (1:10w/v). Sera from \\
children with positive SPT were tested for peanut- \\
specific lgE using ImmunoCAP. \\
Those showing IgE sensitization underwent OFC.
\end{tabular}

UK

UK Evaluation of ethnic differences in nut sensitization
profiles. Sensitization was assessed by SPT.

Participants were recruited prenatally. At the age of 8 years information on exposure and reactivity to peanut was collected by a questionnaire. Peanut sensitization was confirmed by SPT with wheal size of at least $3 \mathrm{~mm}$ greater than the negative control and/measurement of $\lg E(\geq$ $0.2 \mathrm{kU} / \mathrm{A})$ using ImmunoCAP.

Sensitized patients underwent OFC. Three children underwent open OFC with roasted peanuts. Peanut-consuming children underwent open OFC with peanut protein in brownies. All others underwent DBPCFCs with peanut proteincontaining brownies.

The sensitization profile of peanut-allergic children was compared to the profile of those who were considered tolerant using microarray assays. Wheal size $\geq 3 \mathrm{~mm}$ was considered sensitization and $\geq 8 \mathrm{~mm}$ was defined as allergy.
UK Israel
Participants completed validated questionnaires about food allergy (schoolchildren) or food consumption (infants) (period 2004-2005). Food frequency questionnaire was completed by the mothers of the infants. Food allergy questionnaires in primary schools were completed by the children's parents. Children with questionnaire-based peanut allergy were invited for allergy testing (SPT, slgE or both) which was considered positive if results were
933 children at age 8 years (unselected population-based birth cohort)

Data from 2638 patients was
collected (new referrals at the
children's allergy clinic in
Leicester).

Data from 2638 patients was
collected (new referrals at the
children's allergy clinic in
Leicester).

Data from 2638 patients was
collected (new referrals at the
children's allergy clinic in
Leicester).

Data from 2638 patients was
collected (new referrals at the
children's allergy clinic in
Leicester).
1072 mother-child pairs (children aged 3-6 years) were chosen for allergy testing based on valid questionnaire.

Peanut

(tested for

individual

allergen

molecules;

peanut protein

in brownies for

OFC and

DBPCFC; three

children with

milk/egg allergy

underwent open

OFC with

roasted

peanuts)

Almond

Hazelnut

Peanut

Pecan

Brazil nut

Cashew

Pistachio

Walnut

(allergen

whole nuts for

SPT)

The food allergy questionnaire was returned by 4148 Jewish schoolchildren (aged 4-19 years) in the UK and 4672 in Israel. Food frequency questionnaire included 77 Jewish infants (aged 4-24 months) in the UK and 99 in Israel. solutions and

30 of 1072 children (2.8\%)

showed lgE sensitization to peanut, confirmed by positive SPT or high peanut-specific IgE levels (> $\left.100 \mathrm{kU}_{\mathrm{A}} / \mathrm{L}\right)$.

21 children underwent DBPCFC of which 15 had positive results. 5 children had convincing medical history and supportive blood and skin test results.

20 of 1072 children (1.8\%) were considered to have clinical peanut allergy.

110 of 933 children (11.8\%) were considered sensitized to peanut. 19 were not further challenged. 12 children were considered peanut-allergic due to reports of allergic reactions together with $\operatorname{slgE} \geq 15 \mathrm{kU} / \mathrm{L}$ and/or SPT $\geq 8$ $\mathrm{mm}$ without further challenge. Of the remaining 79 subjects that underwent OFC, 7 were considered allergic due to showing objective symptoms. Ara h 2 was the most relevant predictor of clinical peanut allergy.

Nut sensitization (SPT wheal $\geq 3$ $\mathrm{mm}$ ) and allergy (SPT wheal $\geq 8$ $\mathrm{mm}$ ) in south Asian children (percentage of all tested):

Almond: 61.9, 7.4

Brazil nut: $17.2,1.5$

Cashew: 69.1, 27.4

Hazelnut: $30.5,4.2$

Peanut: 63.2, 30.3

Pistachio: 64.3, 25.7

Pecan: 26.9, 8.3

Walnut: $30.1,8.1$

Nut sensitization (SPT wheal $\geq 3$ $\mathrm{mm}$ ) and allergy (SPT wheal $\geq 8$ $\mathrm{mm}$ ) in White children (percentage of all tested):

Almond: $31.1,1.8$

Brazil nut: 20.1, 5.4

Cashew: $35.6,10.6$

Hazelnut: $25.8,2.4$

Peanut: $64.7,36.1$

Pistachio: $31.2,6.9$

Pecan: 24.7, 7.1

Walnut: $20.8,5.4$

Peanut Questionnaire-based peanut Tree nuts allergy prevalence was $1.85 \%$ in (questionnaire the UK and $0.17 \%$ in Israel. Of based; products peanut-allergic children, 58.9\% for allergy (43 of 73) in the UK and $50 \%$ (4 of testing not 8) in Israel had tree nut allergy. further specified) Dietary introduction of peanut occurred earlier in Israel than the UK. At age 9 months, $69 \%$ of 
TABLE 1 | Continued

\begin{tabular}{|c|c|c|c|c|c|}
\hline Region & Test methodology & Subjects tested & $\begin{array}{c}\text { Allergens } \\
\text { tested }\end{array}$ & Results & References \\
\hline
\end{tabular}

$>95 \%$ positive predictive values or in case of positive OFC.

Denmark Questionnaire followed by SPT, histamine release $(\mathrm{HR})$ assay and OFC. Positive SPT was defined as wheal size $\geq 3 \mathrm{~mm}$. Histamine release of $\geq$ $10 \mathrm{ng} / \mathrm{ml}$ was considered as positive. DBPCFC was performed for peanut using peanutcontaining chocolate bars.

Distinction made between primary food hypersensitivity (FHS) (independent of pollen) and secondary FHS (pollen allergic patients).
France

Clinical symptoms of asthma, allergic rhinitis and food allergy assessed using a questionnaire that was completed by the parents. Evaluation of food allergy prevalence and its association with respiratory manifestations of allergy by SPT to food and aeroallergens. For positive SPT wheal size had to be $\geq 3 \mathrm{~mm}$ and greater than the negative control.
Total study population were 1272 unselected young adults (age 22 years), of which 843 responded to questionnaire and were included in the analysis.

total, 6672 schoolchildren (aged 9-11 years) from 108 randomly chosen schools were recruited for clinical examination and completed the questionnaire.

50604 patients (children and adults) at the Helsinki Allergy Hospital (1997-2013), that underwent SPT to at least one nut (18603 birch-positive, 32001 birch-negative).
Investigation of nut sensitization and cross- and co-sensitization to other nuts and birch pollen by using available SPT data. SPT was considered positive if wheal size was at least $3 \mathrm{~mm}$.
Peanut

Almond Hazelnut Brazil nut Walnut (only peanut was used for SPT (fresh peanut) and OFC (peanut in chocolate bars))

Peanut Tree nuts, only listed as "nuts" and not further defined (only peanut was tested by SPT)

Peanut Hazelnut Almond Pistachio Macadamia Walnut Cashew Pecan Brazil nut (for SPT raw nuts were used (prick-to-prick method)) infants in Israel and 10\% in the UK were eating peanuts.

223 of 843 subjects that returned the questionnaire suspected FHS. Of those, 165 self-reported primary FHS (independent of pollen) and 141 secondary FHS (pollen-associated).

\section{Prevalence of primary FHS:}

\section{Peanut:}

Self-reported n (\%): 45 (5.3)

Challenged n: 12

Confirmed by OFC n (\%): 5 (0.6)

Prevalence of secondary FHS

(only self-reported):

Almond n (\%): 2 (0.2)

Brazil nut $\mathrm{n}(\%): 23(2.7)$

Hazelnut $n(\%): 56$ (6.6)

Walnut $n(\%): 4(0.5)$

Reported symptoms of FA, $\mathbf{n}$

Peanut: $21(0.3)$

Nuts: $10(0.2)$

Food sensitization $\mathbf{n}(\%)$ :

Peanuts: 70 (1.1)

Of the children sensitized to at least one food allergen ( $n=119)$, $58.8 \%$ were sensitized to peanut. About 26.7\% were sensitized to at least one aeroallergen.

Of the 10 children that reported symptoms to nuts, $22.2 \%$ were sensitized to birch pollen.

Of 50604 patients that were tested for nuts, $36.8 \%$ were birch positive and $63.2 \%$ were birch-

negative.

Nut sensitization in birchpositive patients (\%):

Hazelnut: 84

Almond: 71

Peanut: 60

Pistachio: 55

Macadamia: 45

Walnut: 41

Cashew: 28

Pecan: 21

Brazil nut: 18

Nut sensitization in birchnegative patients (\%):

Pistachio: 14

Cashew: 12

Walnut: 11

Macadamia: 10

Brazil nut: 8

Pecan: 8

Peanut: 7

Almond: 6

Hazelnut: 5

In a subgroup of patients without birch sensitization, children $<5$

years were most commonly nut- 
TABLE 1 | Continued

\begin{tabular}{|c|c|c|c|c|c|}
\hline Region & Test methodology & Subjects tested & $\begin{array}{c}\text { Allergens } \\
\text { tested }\end{array}$ & Results & References \\
\hline
\end{tabular}

Turkey

Initial selection based on 6963 available questionnaires of subjects with suspected food allergy, followed by a telephone interview. Clinical diagnosis of consented patients by SPT, physical examination, slgE and OFC. SPT was considered positive if wheal size was at least $3 \mathrm{~mm}$ in comparison to the negative control. SlgE was measured by ImmunoCAP.
Turkey Pre-selection by questionnaire, clinical evaluation by SPT and DBPCFC. SPT was considered positive if wheal size diameter was at least $3 \mathrm{~mm}$ in presence of a negative control and a positive histamine reaction after 15 minutes. DBPCFC was preceded by a 7-day elimination diet.
Turkey

Pre-selection of adolescents by parental questionnaire and phone survey. Clinical evaluation in selected patients by SPT (positive if wheal diameter at least $3 \mathrm{~mm}$ ), measurement of specific IgE by ImmunoCAP (>0.35 kU $/ L$ for positive result) and DBPCFC.
Study included 6963

schoolchildren (aged 10-11

years) from the multicenter

ISAAC Phase II study (2005including 909 symptom-positive, 301 SPT-positive and 48 for which applied both were selected and 813 participated in a telephone interview. Of 152 adolescents with current complaints, 87 agreed to clinical investigation.
2006). 1162 children,
2739 of 3500 randomly selected schoolchildren (aged 69 years) from the eastern Black sea region of Turkey returned questionnaire. SPT was performed in 145 children and DBPCFC was performed in 44 children.
10,096 parents of schoolchildren (aged 11-15 years) responded to a questionnaire. Of those, 1139 reported food allergy of their children and were selected for phone survey. Finally, 107 adolescents were selected for clinical evaluation.
Hazelnut

Walnut

Peanut (commercially available extracts for SPT; DBPCFC performed with all three nuts, masked in chocolate pudding) sensitized (8-40\%), with

decreasing prevalence with age. Cross-reactivity was strongest between cashew and pistachio and pecan and walnut.

Peanut

Walnut

Pistachio commercia prick-to-prick testing)

Percentage of parental-reported food allergy prevalence in the ISAAC Phase II study population ( $\mathrm{n}=6963)$ :

Pistachio: 0.8

Walnut: 1.2

Peanut: 1.4

Hazelnut: 1.5

Percentage of SPT-confirmed prevalence in the ISAAC Phase II study population:

Hazelnut: 0.4

Peanut: 0.7

Walnut: 4.5

In total, 12 food allergies were diagnosed in 9 adolescents including allergy to peanut $(n=1)$, hazelnut $(n=1)$ and walnut $(n=$ 3).

Of the 2739 subjects that returned the questionnaire, 156 had parent-reported IgE-mediated food allergy and were further recruited for a second-phase study.

Of these 156 children, 145 underwent SPT of which 48 were considered positive to at least one food. 41 children with positive SPT and 3 with negative SPT underwent DBPCFC. Nuts that were most commonly associated with allergic reactions (of total foods reported ( $n=256$ ), food positive in SPT $(n=88)$ and positive in OFC $(n=22))$ :

\section{Hazelnut:}

Reported n (\%): 8 (3.1)

SPT n (\%): 2 (2.2)

DBPCFC n (\%): 0 (0)

\section{Peanut:}

Reported n (\%): 3 (1.1)

SPT n (\%): 2 (2.2)

DBPCFC n (\%): 0 (0)

Walnut:

Reported n (\%): 3 (1.1)

SPT n (\%): 2 (2.2)

DBPCFC n (\%): 0 (0)

Peanut

Walnut

Hazelnut

Almond

Pistachio

(commercially

available

extracts for

SPT; hazelnut

\section{Walnut (n = 14):}

SPT positive: $4 / 14$

slgE positive: $3 / 14$

DBPCFC: $4 / 5$

Hazelnut ( $n=11)$ :

SPT positive: 1/11
Clinical evaluation $(n=107)$ of

pre-selected patients with
(61)

(62) 
TABLE 1 | Continued

\begin{tabular}{|c|c|c|c|c|c|}
\hline Region & Test methodology & Subjects tested & $\begin{array}{l}\text { Allergens } \\
\text { tested }\end{array}$ & Results & References \\
\hline Russia & $\begin{array}{l}\text { Initially, parents completed the international } \\
\text { ISAAC questionnaire. Based on the questionnaire } \\
\text { two groups of children were formed (with and } \\
\text { without symptoms of allergy). All children } \\
\text { underwent SPT and sera from both groups were } \\
\text { tested for slgE using microarray-based allergen } \\
\text { chip (MeDALL allergen chip). Allergen-specific IgE } \\
\text { level of = or > } 0.3 \text { ISU was considered positive. }\end{array}$ & $\begin{array}{l}\text { In total, } 200 \text { children that } \\
\text { attended the National Research } \\
\text { Center-Institute of Immunology } \\
\text { Federal Medical-Biological } \\
\text { Agency of Russia with their } \\
\text { parents were included in this } \\
\text { study. } \\
\text { Group 1: Children with allergic } \\
\text { symptoms ( } n=103 ; 12.24 \pm \\
2.23 \text { years) } \\
\text { Group 2: Children without } \\
\text { allergic symptoms (Group 2: } \\
n=97 ; 12.78 \pm 2.23 \text { years) }\end{array}$ & $\begin{array}{l}\text { Hazelnut } \\
\text { Peanut } \\
\text { Walnut } \\
\text { Cashew } \\
\text { Pistachio } \\
\text { Brazil nut } \\
\text { (tested for } \\
\text { individual } \\
\text { allergen } \\
\text { molecules) }\end{array}$ & 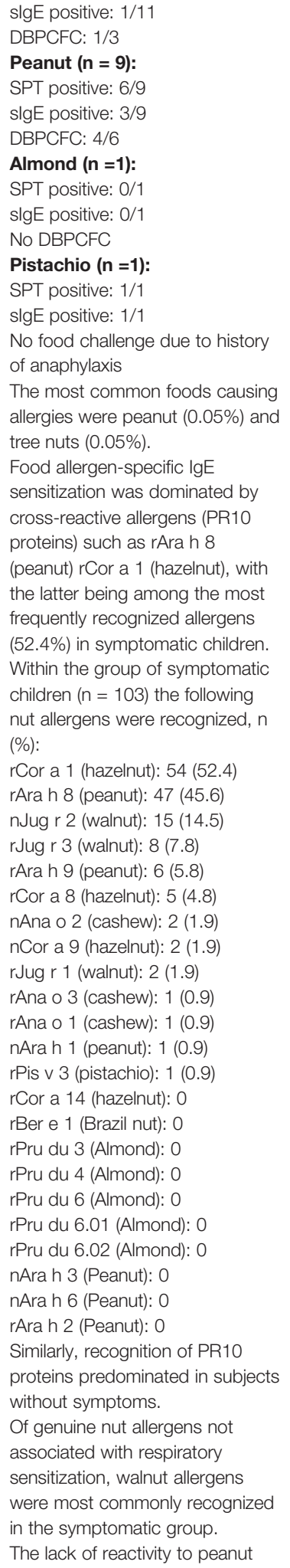 & (38) \\
\hline
\end{tabular}


TABLE 1 | Continued

\begin{tabular}{|c|c|c|c|c|c|}
\hline Region & Test methodology & Subjects tested & $\begin{array}{c}\text { Allergens } \\
\text { tested }\end{array}$ & Results & References \\
\hline
\end{tabular}

storage proteins suggests low prevalence of peanut allergy in

Iran

Initial questionnaire in 2 different groups: population within the Kerman Province, the largest pistachio cultivation region of the world, and a population outside this region. Adults completed the questionnaire themselves or as guardians for their children.

Clinical evaluation by SPT and testing of in vitro cross-reactivity with other nuts by Western blot and inhibition ELISA. SPT was considered positive with a wheal diameter $>3 \mathrm{~mm}$ in regard to the negative control.

Iran Medical record review of patients referred to the Immunology and Allergy Medical Center of Khatam Hospital during a 7-year period (19962003). Patients underwent SPT and responded to a questionnaire. SPT with wheal diameter $>3$ $\mathrm{mm}$ in regard to the negative control and flare diameter of $>10 \mathrm{~mm}$ were considered positive.

South Retrospective medical record review performed in

Korea $\quad 14$ university hospitals in South Korea (20092013) in order to collect cases of anaphylaxis that were caused by peanut, tree nuts or seeds. Measurement of slgE levels using ImmunoCAP and SPT. SPT was considered positive if wheal diameter $>3 \mathrm{~mm}$ or $\geq$ the histamine control.
1724 subjects responded to the questionnaire. Within the pistachio cultivation region were 564 responses (average age $31.35 \pm 13.6$ years). In the population outside this region were 1160 responses received (average age $37 \pm 10$ years). Clinical evaluation of 21 patients.

Testing of IgE-cross-reactivity in 3 pistachio-allergic patients.

1286 allergic patients (aged 279 years) were included.

Pediatricians identified 991 cases of anaphylaxis in patients (< 19 years) based on retrospective medial record review.

IgE data of 104 patients available, 11 patients underwent SPT.

Russia.

Medical records of 15534 patients with suspected allergy were included. The study population included 7388 males and 8146 females (5257 children and 10277 adults). The average age was $30.56 \pm 20.98$ years.

China Parents that attended routine baby health checks with their children at the Department of Primary Child Care, Children's Hospital of Chongqing Medical University were asked to complete a questionnaire. Children underwent SPT. Wheal size of $\geq 3 \mathrm{~mm}$ greater than the negative control was considered positive. Children with positive SPT or positive medical history were asked to undergo OFC (not for peanut).

China Two cross-sectional studies were performed, the first in 1999 and the second in 2009. Children that attended the division of Primary Child Care,
497 infants and young children (aged 0-12 months) were included in the study, of which 477 fully participated.

In total, 401 infants were randomly selected $(0-24$ months), and 382 were included
Pistachio (protein extracts used for SPT)

Cashew

Almond Peanut (protein extracts used for crossreactivity study)

Walnut

Hazelnut on individual allergen molecules)

Peanut Walnut Almond Hazelnut Cashew Pistachio

Pecan Macadamia (products used for testing not specified) (no information

Questionnaires revealed a

pistachio allergy prevalence of $0.65 \%$ within the pistachio cultivation site and a prevalence of $0.3 \%$ for outside this region based on reports of allergic reactions to pistachios. Cross-reactivity between pistachio and cashew was shown, followed by partial cross-reactivity between pistachio and almond (determined by inhibition ELISA).

$29.16 \%$ of patients were sensitized to walnut and $15.32 \%$ were sensitized to hazelnut, determined by positive SPT.

In total, 126 of 991 cases of anaphylaxis were caused by peanut, tree nuts or seeds. Affected patients were between 0.8 and 18.9 years old (over $80 \%$ of children $<7$ years old). Nuts that caused anaphylaxis, $\mathrm{n}$ (\%):

Peanut: 41 (32.5)

Walnut: 52 (41.3)

Cashew: 6 (4.8)

Almond: 3 (2.4)

Hazelnut: 3 (2.4)

Pecan: 3 (2.4)

Pistachio: 1 (0.8)

Macadamia: 1 (0.8)

In 104 cases, slgE levels were measured. Median slgE levels to peanut and walnut were 10.50 and $8.74 \mathrm{kU} / \mathrm{L}$.
Cashew (no information on individual allergen molecules)

Peanut (product used not further specified)
In 46 of 497 cases parents reported allergic reactions of their children to food. 2 subjects had positive SPT to peanut.
(64)

(65)
Peanut

(Extracts or
Of 32 infants with positive SPT in 1999, 1 showed reactivity to peanut. In 2009, 72 infants had 
TABLE 1 | Continued

\begin{tabular}{|c|c|c|c|c|c|}
\hline Region & Test methodology & Subjects tested & $\begin{array}{c}\text { Allergens } \\
\text { tested }\end{array}$ & Results & References \\
\hline
\end{tabular}

Children's Hospital, Chongqing Medical University in the final analysis (in study for well-baby checking were randomly enrolled. Parents completed an initial questionnaire. Subsequently, all subjects underwent SPT. SPT was considered positive if wheal diameter was at least $3 \mathrm{~mm}$ larger than the negative control. Elimination diet was followed by OFC if positive effect of food elimination was observed.

Singapore Retrospective study to evaluate clinical features of peanut allergy in children in the largest pediatric hospital in Singapore.

Peanut allergy was diagnosed based on medical history, together with SPT (positive of wheal diameter of $\geq 3 \mathrm{~mm}$ in comparison to the negative control), slgE (positive for slgE $\geq 0.35$ $\left.\mathrm{KU}_{\mathrm{A}} / \mathrm{L}\right)$ and $\mathrm{OFC}$. from 2009). Results were compared with study from 1999. In 1999, 314 questionnaires were returned and infants were skin prick tested. 10 infants dropped out during food elimination, thus, 304 were included in the final analysis.

269 children ( $\leq 16$ years old) with clinical diagnosis of peanut allergy were included.

p

technique used positive SPT, including 6 that

for SPT; peanut reacted to peanut.

butter used for In 1999, peanut was among the

oral offending foods causing food

provocation) allergy in infants (observed in 1 of

11 children with challenge-

confirmed food allergy). In 2009,

confirmed food allergy only

included egg and cow's milk.

Peanut

Cashew

Almond

Hazelnut

Walnut

(SPT with

commercial

extracts; OFC

using peanut

butter or

roasted

peanuts)

269 patients that were diagnosed

with peanut allergy were identified, together with 59 patients that were considered peanut tolerant (positive SPT, but tolerant to peanut ingestion). In the peanut allergy group, the median age of first allergic presentation was at

24 months. The rate of anaphylactic reactions in the study population was $7.1 \%$.

In the peanut allergy group, $32.3 \%$ were also sensitized to the following tree nuts: cashew nut (17.1\%), almond (15.6\%), hazelnut (15.6\%), walnut (14.1\%).

Singapore Administration of a questionnaire to assess Philippines prevalence of peanut and tree nut allergy in Singapore (local and expatriate) and Philippine schoolchildren of different age groups. Allergy diagnosis was based on convincing history which was defined by reports on the appearance of specific allergic symptoms within two hours after food ingestion.

In total, 25,692 schoolchildren responded to the survey. Of these, 23,425 children (4-6 and 14-16 years) were included in the final analysis. The analysis included 4515 local Singapore children (4-6 years old), 6498 local Singapore children (14-16 years old), 978 Singapore expatriates (4-6 and 14-16 years old) and 11434 Philippine children (14-16 years old).
Peanut "Tree nuts" including the following: Almond Brazil nut Cashew Hazelnut Macadamia Pecan Walnut (only questionnaire based)

\section{Peanut allergy prevalence} based on convincing history: Singapore (4-6 years: $0.64 \%$ Singapore ( $14-16$ years): $0.47 \%$ Philippines (14-16 years): $0.43 \%$

Tree nut allergy prevalence based on convincing history: Singapore ( $4-6$ years): $0.28 \%$ Singapore ( $14-16$ years): $0.30 \%$ Philippines (14-16 years): 0.33\% Higher rates of peanut and tree nut allergy were reported in Singapore expatriates: Peanut (4-6 years): $1.29 \%$ Peanut (14-16 years): $1.21 \%$ Tree nuts (4-6 years): $1.12 \%$ Tree nuts (14-16 years): 1.21 Most common reported tree nuts (decreasing order of frequency) were cashew, hazelnut, almond, walnut, macadamia, pistachio, pecan and Brazil nut. with positive SPT or peanut-specific ImmunoCAP FEIA $<0.35 \mathrm{kU}_{\mathrm{A}} / \mathrm{L}$ were selected (2003-2006). Eligible patients completed a questionnaire. Specific serum IgE to Ara h 1, Ara h 2 and Ara h 3 was detected by ELISA. Peanut-specific IgE was detected using CAP-FEIA.

Singapore Retrospective study of Singaporean children that experienced anaphylaxis and visited a tertiary pediatric hospital between 2005-2009. Patients with history of anaphylaxis underwent SPT. SPT was considered positive if wheal size was $\geq 3$ $\mathrm{mm}$ compared to the negative control. years) included in study (108
31 patients (aged 0.7-13.2 years) consented to the study (of 62 eligible patients).

Peanut (specific lgE to Ara h 1, 2, 3 was measured; commercial extracts used for SPT)

98 children (aged 3.6-10.8 cases of anaphylaxis).

Peanut

Tree nuts (commercial
SPT wheal size of the 31 tested patients ranged from 3-17 $\mathrm{mm}$. 28 patients had positive peanutspecific lgE. 87.1\% had lgE specific to Ara h $1,87.1 \%$ to Ara h 2 and $54.8 \%$ to Ara h 3. extracts used for SPT)
Peanut was the most common food trigger of anaphylaxis (19\%). Tree nuts accounted for $4 \%$ of anaphylaxis. 
TABLE 1 | Continued

\begin{tabular}{ll}
\hline Region & \multicolumn{1}{c}{ Test methodology } \\
\hline Taiwan & $\begin{array}{l}\text { Serum was collected and slgE to individual nuts } \\
\text { was measured (positive if slgE } \geq 0.35 \mathrm{kU} / \mathrm{L} \text { ) } \\
\text { using ImmunoCAP. }\end{array}$ \\
Japan & $\begin{array}{l}\text { A questionnaire was provided to the particip } \\
\text { in order to collect data on anaphylaxis-causing } \\
\text { foods. } \\
\text { USA }\end{array}$ \\
& \\
Follow-up study to determine prevalence of \\
peanut and tree nut allergy in the USA by a \\
nationwide, cross-sectional random phone \\
survey. Allergic reactions were considered \\
specifically defined allergic \\
\end{tabular}

In total, 2633 patients (of all Hazelnut ages and gender) were included Peanut in the serological testing. In the Almond final analysis, 1795 patients with Cashew

suspected clinical allergy were Pecan included.
333 patients (aged 2-93 years) from the outpatient department of Kaohsiung Veterans General Hospital, Taiwan that showed symptoms of asthma, atopic dermatitis and allergic rhinitis were included in the study (from 2014-2017).

1383 individuals from 878 families (including 319 patients with history of anaphylaxis) provided a valid questionnaire. Average age was 11.25 years (range, 0-93 years). The most frequently recorded age was 5 years.

5300 households $(13,534$ subjects) were surveyed (children and adults from 0 to $\geq 65$ years).
Peanut

Cashew

Brazil nut

Almond

(no information

on individual

allergen

molecules)

Peanut

(only questionnaire

based)

Peanut

Walnut

Cashew

Pecan

Almond

Pistachio

Brazil nut

Macadamia

(only

questionnaire

based) (no information on individual allergen molecules)

Mexico

Prevalence of peanut and tree nut allergy in Mexican adults assessed based on a survey. Probably allergy was defined by reports of specific allergic symptoms appearing within two hours after food ingestion.
1126 participants $(50.1 \%$ young Peanut adults aged 18-24 years and Pecan 49.9\% adults aged 25-50 years) Hazelnut were included in the study.

\section{Pistachio}

Almond

(only
In total, 555 slgE data were available, of which 339 were considered as food sensitization $(\geq 0.35 \mathrm{kU} / \mathrm{A})$, including peanut ( $n=124,36.6 \%)$, cashew nut $(n=64,18.9 \%)$, Brazil nut $(\mathrm{n}=28,8.3 \%)$ and almond $(n=73,21.5 \%)$.

27 of 319 patients $(8.5 \%)$ reported peanut-related anaphylaxis. In comparison, anaphylaxis to milk, eggs and wheat was reported by 221 (69.3\%), 144 (45.1\%) and 92 (28.8\%) patients, respectively.

Overall prevalence of peanut allergy (children and adults): $0.8 \%$ Overall prevalence of tree nut allergy (children and adults): $0.6 \%$ For children $<18$ years the prevalence of peanut or tree nut allergy was $2.1 \%$, compared with $1.2 \%$ in 2002 and $0.6 \%$ in 1997. Number of participants reporting tree nut allergy:

Walnut: 41

Cashew: 29

Pecan: 26

Almond: 25

Pistachio: 19

Brazil nut: 19

Hazelnut: 17

\section{Macadamia: 17}

Hazelnut, peanut and almond were among the 15 most frequent foods with positive slgE $(\geq 0.35$ $\mathrm{KU}_{\mathrm{A}} / \mathrm{L}$ ) results (number of tested patients and \% of positive results of all patients tested for this food): Hazelnut: 63, 49\%

Peanut: 219, 25\%

Almond: 65, 18\%

Sensitization to peanut and tree nuts was more frequent in older children (aged 6-17 years). In the group of foods with low sample size $(<50)$ cashew showed high positivity: of 22 patients tested, $27.3 \%$ had slgE levels of $\geq 0.35 \mathrm{kU}_{\mathrm{A}} / \mathrm{L}$ and $13.6 \%$ had slgE levels of $\geq 0.71 \mathrm{kU}_{\mathrm{A}} / \mathrm{L}$. Of 34 patients that were tested to pecan, $14.7 \%$ had both slgE levels of $\geq 0.35 \mathrm{kU} / \mathrm{L}$ and $\geq 0.71$ $\mathrm{KU}_{\mathrm{A}} \mathrm{L}$.

Due to lack of documented adverse reactions to hazelnuts, pistachios, and almonds in the tree nut category perceived and probable allergy applied only for pecan and was $0.4 \%$ and $0.3 \%$,
References

Previous studies: $(77,78)$ 
TABLE 1 | Continued

\begin{tabular}{ll}
\hline Region & \multicolumn{1}{c}{ Test methodology } \\
& \\
Canada $\quad$ Food allergy prevalence was assessed by a \\
random telephone survey. \\
Food allergy was either defined as perceived (self- \\
report), probable (convincing history or reported \\
confirmation by a physician) or confirmed \\
(convincing medical history and confirmatory test \\
results). \\
Confirmatory test results included positive SPT \\
(wheal size at least 3 mm greater than the \\
negative control), food specific serum lgE levels of \\
IgE $\geq 0.35 \mathrm{k} \mathrm{A}_{\mathrm{A}} / \mathrm{L}$ or positive OFC. Additionally, \\
patients that had uncertain clinical history were \\
considered having confirmed allergy if they had \\
positive $S P T$ together with slgE of $\geq 15 \mathrm{kU} / \mathrm{L}$ for \\
peanut and tree nut or positive $S P T$ together with \\
positive OFC or OFC alone.
\end{tabular}

Australia Parents completed an initial questionnaire. Detection of lgE sensitization to foods in 1-yearold infants by SPT and those with sensitization in SPT (wheal size $\geq 1 \mathrm{~mm}$ compared to the negative control) underwent OFC.

\section{Australia At age 1 year:}

Tree nut sensitization was defined by SPT wheal size of at least $3 \mathrm{~mm}$ (compared to the negative control) to almond, cashew or hazelnut.

Tree nut tolerance was defined by history of tolerance to food ingestion or negative SPT.

Parent reported tree nut allergy was defined by reports of specific allergic reactions.

No OFC for tree nuts was performed at age 1, but OFC performed for peanut. Sensitized tolerance to peanut was defined by SPT wheal size of at least $2 \mathrm{~mm}$ and negative OFC.

Peanut allergy was defined by SPT wheal size of at least $2 \mathrm{~mm}$ and positive OFC.

\section{At age 6 years:}

Tree nut sensitization was defined by SPT with wheal size of at least $3 \mathrm{~mm}$ (compared to the negative control) to almond, Brazil nut, cashew, hazelnut, macadamia, pecan, pistachio or walnut. Definite tree nut allergy was defined by positive OFC and IgE sensitization or history of objective symptoms or positive OFC at age 4 years and SPT wheal size of $8 \mathrm{~mm}$ at age 6 years.

Probable tree nut allergy was defined by SPT response of at least $8 \mathrm{~mm}$, without reaction

Subjects tested

Allergens

tested

Of 10596 households, 3613 (9667 individuals) completed interview and were included in the analysis. Participation was eligible if respondents were 18 years or older. However, respondents also provided information on any additional allergic household member. based)

Peanut

Tree nut (not

distinguished

between

individual tree

nuts)

(only

questionnaire

based) questionnaire

respectively.

Perceived and probably peanut

allergy was both $0.6 \%$.

Peanut allergy prevalence (\%):

\section{Children:}

Perceived: 1.77

Probable: 1.68

Confirmed: 1.03

Adults:

Perceived: 0.78

Probable: 0.71

Confirmed: 0.26

Entire study population:

Perceived; 1.00

Probable: 0.93

Confirmed: 0.61

Tree nut allergy prevalence

(\%):

Children:

Perceived; 1.73

Probable: 1.59

Confirmed: 0.69

Adults:

Perceived: 1.07

Probable: 1.00

Confirmed: 0.35

\section{Entire study population:}

Perceived; 1.22

Probable: 1.14

Confirmed: 0.68

2848 infants (12 months old) were included in the study. Of those, 45 did not undergo SPT because they had been already tested by their doctor.

Initially, 5276 1-year-old children Cashew were recruited.

3232 participated in the followup study at age 6 years and completed questionnaire and SPT assessment, while 1222 completed questionnaire only.

Peanut Prevalence of sensitization to (products used peanut was $8.9 \%$ (wheal size $\geq 1$ not further $\quad \mathrm{mm}$ ). Prevalence of clinically specified) relevant sensitization (SPT $\geq 3$ $\mathrm{mm}$ ) to peanut was $6.4 \%$. Peanut allergy prevalence confirmed by OFC was 3.0\%.

Of the 5276 infants that participated in the study, 924 had positive SPT results to egg, sesame, peanut, shrimp or cow's milk. The positive-tested infants further attended OFC clinic and had SPT to tree nuts. Food allergy to egg, peanut or sesame was confirmed by OFC in 530 patients. Tree nut sensitization at age 1 year:

Of patients with challengeconfirmed food allergy, 31\% were sensitized to at least 1 tree nut. Tree nut sensitization was more common in infants with both peanut and egg allergy.

\section{Tree nut sensitization at age 6} years:

234 children were sensitized to tree nuts at the age of 6 , corresponding to $7.3 \%$ of all that underwent SPT to tree nuts ( $\mathrm{n}=$ 3232).

154 children were considered 
TABLE 1 | Continued

\begin{tabular}{ll}
\hline Region & \multicolumn{1}{c}{ Test methodology } \\
\hline & history or previous OFC result, SPT wheal size of \\
$3-7$ mm at age 6 years together with positive \\
OFC at 4 years of age, history of objective \\
symptoms or report of food avoidance due to \\
allergy. \\
Tree nut tolerance was defined by negative OFC \\
result, SPT wheal size of 0-2 mm, SPT response \\
of 3-7 mm and reported food ingestion, or lack of \\
reaction since age 4 years without food \\
avoidance.
\end{tabular}

Australia Preselection by questionnaires for students and parents. Clinical evaluation in eligible students by SPT and OFC in case of SPT result with wheal size of at least $3 \mathrm{~mm}$. Current clinical food allergy was defined by positive OFC or convincing history including data on IgE sensitization (SPT wheal size of $>3 \mathrm{~mm}$ or slgE $\left.>0.35 \mathrm{kU}_{\mathrm{A}} / \mathrm{L}\right)$, or SPT with wheal size of $>8$ $\mathrm{mm}$.

$\begin{array}{ll}\text { South } & \text { Evaluation of IgE sensitization to several allergen } \\ \text { Africa } & \text { molecules by using an allergen microarray (ISAC } \\ & \text { technology-based). Values } \geq 0.1 \text { ISU were } \\ & \text { considered positive. }\end{array}$

Zimbabwe Sera from peanut-sensitized and peanut-allergic Sweden patients were analyzed for IgE to Ara h 1-3, 6, 8 and 9 using an allergen microarray. IgE levels were considered low (0.35-1 ISU-E), moderatehigh (> 1-15 ISU-E) or very high (> 15 ISU-E). Allergen-specific IgE to peanut extract was measured by ImmunoCAP $\left(\geq 0.10 \mathrm{kU}_{\mathrm{A}} / \mathrm{L}\right.$ for positive result).
9816 randomly selected students (aged 10-14 years) provided either a student questionnaire (history of food allergy) or a parent questionnaire (history of food allergy and additional

information).

5016 students were included in the clinical evaluation. (aged 9-38 months) from urban and rural areas with and without atopic dermatitis (AD) were included:

Urban AD ( $\mathrm{n}=32)$ Urban non-AD ( $\mathrm{n}=40)$ Rural AD ( $n=49)$ Rural non-AD ( $n=45)$

\section{Peanut}

Tree nuts:

Cashew

Pistachio

Walnut

Hazelnut

Macadamia

Pecan

Almond

Brazil nut (products used

not further specified)

Peanut (tested

for individual allergen molecules) mociles)

(1)

54 peanut-sensitized patients from Zimbabwe (aged 0.9-59 years), 25 peanut-allergic (aged 3-15 years) and 25 peanutsensitized, but tolerant patients (aged 3-18 years) from Sweden were included.

\section{Peanut (tested for individual allergen molecules) \\ $46 \%$ of African patients and all of the peanut-allergic Swedish patients had IgE to at least one highly allergenic peanut allergen (Ara h 1, 2, 3, 6 or 9). Of the African patients, $48 \%$ showed IgE toward cross-reactive carbohydrate determinants (CCDs). $60 \%$ of Swedish peanut-tolerant patients had lgE to Ara h 8.}

allergic to at least one tree nut. Cashew was the most common tree nut causing allergy (2.7\%), followed by hazelnut $(0.9 \%)$ and almond $(0.3 \%)$.

Other tree nuts allergies were diagnosed in $<1.0 \%$ of the subjects (pistachio, $n=50$; walnut, $\mathrm{n}=28$; macadamia, $\mathrm{n}=$ 12; pecan, $\mathrm{n}=8$; and Brazil nut, $\mathrm{n}=5$ ).

Clinical-defined current food allergy in the clinical group ( $\mathrm{n}=$ 5016) had a prevalence of $4.5 \%$. The most common foods causing allergy in the clinical group were peanut $(2.7 \%)$ and tree nuts (2.3\%).

Among tree nuts, cashew was most prevalent (1.6\%), followed by pistachio (1.0\%), walnut $(0.7 \%)$, hazelnut $(0.7 \%)$, macadamia $(0.2 \%)$, pecan $(0.2 \%)$, almond $(0.1 \%)$ and Brazil nut (0.1\%).

$31 \%$ of urban and $41 \%$ of rural AD patients were sensitized to at least one peanut allergen. However, self-reported peanut exposure was significantly higher in urban (79\%) than rural (39\%) regions. In non-AD children sensitization was significantly lower. Ara h 2 (29\% rural, 19\% urban $\mathrm{AD}$ children) and Ara h 6 (25\% rural, 22\% urban AD children) were most commonly recognized.

Listed are studies investigating prevalences of allergy to different nuts as determined by different methodologies in different populations with the corresponding references.

region. However, for improved nut allergy management it is more relevant to consider the sensitization profile of nut allergic patients on a molecular level. As an example, sensitization to allergens of the family of pathogenesis-related class 10 (PR-10) proteins is widespread in northern countries, while IgE reactivity to non-specific lipid transfer proteins (nsLTPs) is predominant in the Mediterranean region. Molecular diagnostics significantly helps to distinguish between cross-reactive allergens and those that are a true indicator of sensitization to a particular nut.
In Europe, regional as well as ethnical differences in the sensitization profile of nut allergic patients have been observed $(48,50,56)$. Generally, self-reported prevalence is significantly higher than food challenge-confirmed nut allergy (58). Several studies that investigated peanut allergy prevalence in Europe revealed varying prevalence rates $(53-55,59)$. In Russia, peanut allergy does not seem to play a major role in food allergy (38). Peanuts and cashew nuts are among the most common elicitors of anaphylaxis (85). Co-sensitization to different nuts correlates 
strongest between nuts of the same botanical family such as cashew and pistachio or pecan and walnut (60).

In the US, peanut is one of the most common foods causing allergy (76-78). Among tree nuts, walnut and cashew cause most of the allergic reactions, followed by almond, pistachio, Brazil nut, hazelnut and macadamia (76). Similar results were seen in a Canadian study with peanut allergy being most prevalent, predominantly in children (81).

In Central and South America, few studies reported sensitization of allergic patients to peanut and almond, although in this region, allergy to nuts seems to be low in general $(79,80,86,87)$. In most Latin American countries, frequent foods that cause allergy include fish, seafood, milk, egg, vegetables and fruits $(87,88)$.

In Asia, peanut allergy prevalence seems to be low compared to US and certain western countries $(76,89-92)$. Cashew nut is one of the most common reported tree nuts causing allergy in Asia $(67,70,71,74)$. However, tree nut allergy prevalence varies significantly across Asia especially between East and Southeast Asia and the Middle East $(62,63,66,70,74)$. It can be assumed that the availability of nuts in certain regions contributes to the prevalence of allergies to these nuts, as can be seen by the increased frequency of pistachio allergy in pistachio cultivation regions (64).

In Australia, peanut allergy is one of the most frequent elicitors of IgE-mediated food allergy $(49,93)$. Tree nut allergy in Australia is less common than peanut allergy and prevalence rates of individual tree nut allergies vary significantly between studies $(82,83,93)$.

Peanut allergens are the most frequently recognized nut allergens in South Africa (84) as determined in allergic children whereas IgE recognition of peanut allergens seems to be often asymptomatic as reported for Zimbabwe (52) but data regarding the prevalence of nut allergies in Africa are rare.

Figure 2 provides an overview of the role of different nuts as allergen sources for different regions of the world. Peanut allergy seems to be most frequent in most parts of the world whereas in Europe hazel nut allergy seems to be more important. Interestingly, different molecular IgE sensitization patterns can be observed in different geographic regions depending on birch pollen exposure involving IgE reactivity to Ara $\mathrm{h} 8$, sensitization to lipid transfer proteins in southern Europe with sensitization to Ara $h$ 9, and the classical peanut sensitization involving storage proteins such as Ara h 1, Ara h 2, Ara h 3 and Ara h 6 (94-96). In South America, nut allergy seems to be less common than in other parts of the world. Only few data are available for Africa indicating a need for further studies. It seems that early introduction of peanut in the diet as it occurs in Zimbabwe results in a low rate of symptomatic peanut allergy (52).

Notably, reports on the prevalence of nut allergies among adults are rare and most studies have been conducted in children. More studies taking into account the molecular IgE sensitization profiles and symptoms verified by highly indicative case history and/or provocation testing in children and adults are needed to obtain a more complete picture of the dominating nut allergies in different parts of the world.

\section{CLINICAL RELEVANCE OF NUT ALLERGEN MOLECULES}

Peanut allergy is a good example for the importance of molecular diagnosis for identifying the culprit sensitizing allergen source. Patients may be allergic to peanut due to primary sensitization to

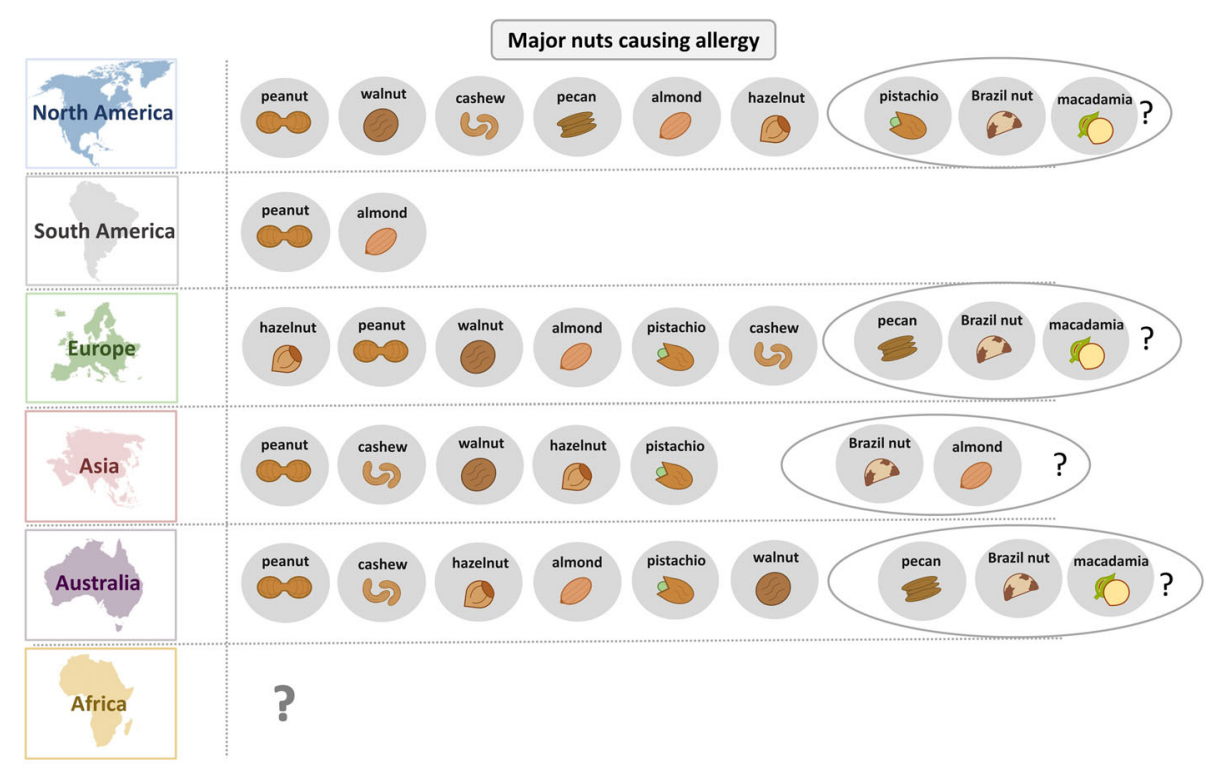

FIGURE 2 | Overview of the relevance of different nuts as allergen sources in different parts of the world. 
birch pollen and cross-reactivity of PR-10 allergen (i.e., crossreactivity between Bet $\mathrm{v} 1$ and Ara $\mathrm{h}$ 8), some are sensitized to lipid transfer proteins from fruits and eventually certain pollen (e.g., cross-reactivity between Pru p 3 and Ara h 9), others may be genuinely sensitized to peanut and the corresponding peanutspecific marker allergens (Ara h 1, 2, 3 and 6) and there can be mixed sensitizations (94-96). The deconvolution of the molecular IgE sensitization profiles is therefore of high importance for identifying the genuinely sensitizing allergen source, predicting clinical manifestations (mild or severe forms of allergy), prevention and treatment based on avoidance/diet and AIT (13). New approaches for the diagnosis and therapy of nut allergies will be increasingly based on individual nut allergen molecules. The clinical relevance of different allergens significantly varies by region and age. In the overview of nut allergen molecules in Table 2 (94, 97-161) a clear distinction has been made between cross-reactive class I food allergens, such as lipid transfer proteins, and confirmed and putative class II food allergens. Key references are given for each of the allergen molecules and reference is made to the WHO/IUIS allergen nomenclature data base $(94,97-161)$.

\subsection{Overview of Source-Related Nut Allergen Molecules \\ 3.1.1 Peanut}

At present, 17 peanut (Arachis hypogaea) allergens - Ara h 1 to Ara h 18 - have been identified, with exception of Ara h 4 which was identified as isoform of Ara h 3 (97) (Table 2). Peanut allergens belong either to the prolamin superfamily (Ara h 2, Ara h 6, Ara h 7, Ara h 9, Ara h 16, Ara h 17), the cupin superfamily (Ara h 1, Ara h 3) or different other proteins such as profilin (Ara h 5), Bet v 1-like (Ara h 8), oleosins (Ara h 10, Ara h 11, Ara h 14, Ara h 15) or defensins (Ara h 12, Ara h 13) (97). Recently, the cyclophilin-peptidyl-prolyl cis-trans isomerase Ara h 18 was officially recognized as peanut allergen by the WHO/IUIS Allergen Nomenclature Sub-committee (97).

In America, Central and Northern Europe, Ara h 1 and Ara h 2 are major peanut allergens $(94,99)$. Valcour et al. showed that in the US, patients with reported peanut allergy most frequently recognized Ara h 2 but IgE reactivity to Ara h 1 and Ara h 3 was also highly prevalent in the tested patients (104). Kleber-Janke et al. reported IgE reactivity to Ara h 1 in $65 \%$ and to Ara h 2 in $85 \%$ of sera from patients $(n=40)$ with reported peanut allergy $(100)$. Koppelman et al. compared the IgE reactivity of 32 peanut-allergic patients to Ara h 1, Ara h 2 and Ara h 3 and showed that of these three allergens, Ara h 2 was most frequently recognized (26/32) (102). Importantly, sensitization to Ara h 2 is associated with severe allergic reactions (103). Ara h 2 further has the potential to crossreact with other $2 S$ albumins such as Ara h 6 and Ara h 7, with Ara h 2 possibly representing the primary sensitizing agent $(108,162)$. However, in rare cases, monosensitization to Ara h 6 and Ara h 7 might be observed and thus must be considered for accurate diagnosis $(108,163)$. It has been shown that detection of IgE reactivity to peanut extract together with reactivity to rAra $h 2$ and rAra h 6 allows reliable peanut allergy diagnosis and Ara h 2 could significantly increase diagnostic specificity (164).
In comparison to Ara h 1 and Ara h 2, sensitization to Ara h 3 is less frequently observed $(94,102,105)$.

In the Mediterranean region, sensitization to the nsLTP Ara $h$ 9 is common and has high cross-reactive potential with homologous allergens of the Rosaceae family, in particular the peach nsLTP Pru p $3(94,110,111,165)$.

Schwager et al. reported sensitization to peanut oleosins in patients with a history of severe allergic reactions (113). According to the authors, roasting of peanuts seemed to increase the IgE-binding capacity of oleosins. Previously, several studies have reported that roasting might enhance the allergenic activity of peanut allergens (166-169).

So far, little is known regarding the clinical relevance of peanut defensins and the nsLTPs Ara h 16 and Ara h 17 as well as the currently approved cyclophilin-peptidyl-prolyl cistrans isomerase Ara h 18 which may be cross-reactive with corresponding pollen and respiratory allergens.

\subsubsection{Walnut}

For the English walnut (Juglans regia), which belongs to the Juglandaceae family, 8 allergens have been officially approved by the allergen nomenclature (Jug $\mathrm{r} 1$ to 8 ), making it the clinically most relevant walnut species $(97,116)$ (Table 2). For the black walnut (Juglans nigra) 3 allergens have been identified (Jug n 1, 2, 4) (97). However, their clinical relevance is not yet well described in the literature.

Teuber et al. reported that 12 out of 16 walnut-allergic patients showed IgE reactivity to a $2 \mathrm{~S}$ albumin from English walnut, designated Jug $r$, thus identifying it as a major walnut allergen (115).

IgE reactivity to another major walnut allergen, the vicilin Jug r 2, was detected in 9 out of 15 patients from the US (117). In a study by Pastorello et al., IgE reactivity to vicilin-like protein precursors and vicilin precursors of $9 \mathrm{kD}$ was observed in 10 out of 46 sera from Italian patients, suggesting a minor role of vicilins in allergic patients in the Mediterranean region (118).

Pastorello et al. further reported that 37 out of 46 sera showed IgE binding to the walnut nsLTP Jug $r$ 3, leading to the conclusion that in southern Europe, Jug r 3 represents a major allergen of walnut (118). Notably, peach LTP (Pru p 3) completely inhibited IgE binding to Jug $\mathrm{r} 3$, indicating strong cross-reactivity between walnut and peach.

In 2003, Teuber et al. observed IgE sensitization of patients who experienced life-threatening systemic reactions after walnut consumption to a walnut protein of the legumin group, designated Jug r 4 (119). IgE binding to a recombinant Jug r 4 fusion protein was observed in 15 out of 23 tested sera, suggesting major importance of Jug $\mathrm{r} 4$ in patients with confirmed symptoms. Another study showed IgE reactivity to recombinant Jug r 4 in 21 out of 37 sera from walnut-allergic patients (120).

Jug r 6, like Jug r 2 and Jug $r 4$, is a member of the cupin superfamily. Although Jug r 2 and Jug r 6 belong to the same protein family, they share only $44 \%$ identity (122). In comparison to Jug $\mathrm{r} 2$, which was identified as a major walnut allergen by Teuber et al., Jug r 6 showed IgE reactivity in 20 of 77 walnut-allergic patients, 
TABLE 2 | Nut allergen molecules according to the WHO/IUIS allergen nomenclature (97) including information regarding biochemical, immunological and clinical features with key references.

\begin{tabular}{|c|c|c|c|c|c|c|c|c|}
\hline Species & Allergen name & $\begin{array}{l}\text { Protein } \\
\text { family }\end{array}$ & Function & MW (SDS-PAGE): & $\begin{array}{c}\text { Route of } \\
\text { sensitization }\end{array}$ & Prevalence & $\begin{array}{l}\text { Clinical rele- } \\
\text { vance }\end{array}$ & References \\
\hline \multirow[t]{11}{*}{$\begin{array}{l}\text { Arachis } \\
\text { hypogaea } \\
\text { (peanut) }\end{array}$} & Arah 1 & Vicilin & $\begin{array}{l}\text { Seed storage } \\
\text { protein }\end{array}$ & $64 \mathrm{kDa}$ & Food & $\begin{array}{l}\text { Major allergen in the US, } \\
\text { central and northern } \\
\text { Europe }\end{array}$ & $\begin{array}{l}\text { Risk of severe } \\
\text { allergic reactions } \\
\text { up to } \\
\text { anaphylaxis }\end{array}$ & $\begin{array}{l}(94,98- \\
100)\end{array}$ \\
\hline & Ara h 2 & 2S albumin & $\begin{array}{l}\text { Seed storage } \\
\text { protein }\end{array}$ & $17 \mathrm{kDa}$ & Food & $\begin{array}{l}\text { Major allergen in the US, } \\
\text { central and northern } \\
\text { Europe }\end{array}$ & $\begin{array}{l}\text { Risk of severe } \\
\text { allergic reactions } \\
\text { up to } \\
\text { anaphylaxis }\end{array}$ & $\begin{array}{c}(94,99- \\
104)\end{array}$ \\
\hline & Ara h 3 & Legumin & $\begin{array}{l}\text { Seed storage } \\
\text { protein }\end{array}$ & $\begin{array}{l}60 \mathrm{kDa}, 37 \mathrm{kDa} \\
\text { (fragment) }\end{array}$ & Food & $\begin{array}{l}\text { Prevalence varies between } \\
\text { studies, but generally more } \\
\text { prevalent in Central and } \\
\text { North America and } \\
\text { Northern Europe than in } \\
\text { Mediterranean regions }\end{array}$ & $\begin{array}{l}\text { Risk of severe } \\
\text { allergic reactions } \\
\text { up to } \\
\text { anaphylaxis }\end{array}$ & (105) \\
\hline & Ara h 7 & 2S albumin & $\begin{array}{l}\text { Seed storage } \\
\text { protein }\end{array}$ & $15 \mathrm{kDa}$ & Food & $\begin{array}{l}\text { Reactivity usually in } \\
\text { patients who are primarily } \\
\text { sensitized to Ara h } 2 \text {, but } \\
\text { monosensitization possible }\end{array}$ & $\begin{array}{l}\text { Predictive ability } \\
\text { for peanut } \\
\text { allergy similar to } \\
\text { Ara h } 2 \text { and Ara } \\
\text { h } 6\end{array}$ & $\begin{array}{c}(100,107, \\
108)\end{array}$ \\
\hline & Ara h 8 & $\begin{array}{l}\text { PR-10 (Bet v } \\
\text { 1-like) }\end{array}$ & $\begin{array}{l}\text { Plant defense, } \\
\text { stress } \\
\text { mechanisms }\end{array}$ & $17 \mathrm{kDa}$ & Food & $\begin{array}{l}\text { Panallergen (class II food } \\
\text { allergy) }\end{array}$ & $\begin{array}{l}\text { Pollen-food } \\
\text { allergy syndrome }\end{array}$ & $\begin{array}{c}(94,104 \\
109)\end{array}$ \\
\hline & Ara h 9 & nsLTP1 & $\begin{array}{l}\text { Transfer of } \\
\text { lipids across } \\
\text { membranes, } \\
\text { plant defense, } \\
\text { response to } \\
\text { environmental } \\
\text { stress }\end{array}$ & $9.8 \mathrm{kDa}$ & Food & $\begin{array}{l}\text { Major allergen in the } \\
\text { Mediterranean region }\end{array}$ & $\begin{array}{l}\text { Severe allergic } \\
\text { reaction }\end{array}$ & $\begin{array}{c}(94,110 \\
111)\end{array}$ \\
\hline & Ara h 12 & Defensin & Plant defense & $\begin{array}{l}8 \mathrm{kDa} \text { (reducing), } \\
12 \mathrm{kDa} \text { (non- } \\
\text { reducing), } 5.184 \\
\mathrm{kDa} \text { (mass) }\end{array}$ & Food & Not yet reported & $\begin{array}{l}\text { Might be } \\
\text { associated with } \\
\text { severe allergic } \\
\text { reactions }\end{array}$ & (114) \\
\hline & Ara h 13 & Defensin & Plant defense & $\begin{array}{l}8 \mathrm{kDa} \text { (reducing), } \\
11 \mathrm{kDa} \text { (non- } \\
\text { reducing), } 5.472 \\
\mathrm{kDa} \text { (mass) }\end{array}$ & Food & Not yet reported & $\begin{array}{l}\text { Might be } \\
\text { associated with } \\
\text { severe allergic } \\
\text { reactions }\end{array}$ & (114) \\
\hline & Ara h 14 & Oleosin & $\begin{array}{l}\text { Structural } \\
\text { protein of oil } \\
\text { bodies }\end{array}$ & $17.5 \mathrm{kDa}$ & Food & Not yet reported & $\begin{array}{l}\text { Might be } \\
\text { associated with } \\
\text { severe allergic } \\
\text { reactions }\end{array}$ & $(112,113)$ \\
\hline & Ara h 15 & Oleosin & $\begin{array}{l}\text { Structural } \\
\text { protein of oil } \\
\text { bodies }\end{array}$ & $17 \mathrm{kDa}$ & Food & Not yet reported & $\begin{array}{l}\text { Might be } \\
\text { associated with } \\
\text { severe allergic } \\
\text { reactions }\end{array}$ & $(112,113)$ \\
\hline & Ara h 16 & nsLTP2 & $\begin{array}{l}\text { Transfer of } \\
\text { lipids across }\end{array}$ & $\begin{array}{l}8.5 \mathrm{kDa} \text { by SDS- } \\
\text { PAGE reducing }\end{array}$ & Food & Not yet reported & Not yet reported & (97) \\
\hline
\end{tabular}


TABLE 2 | Continued

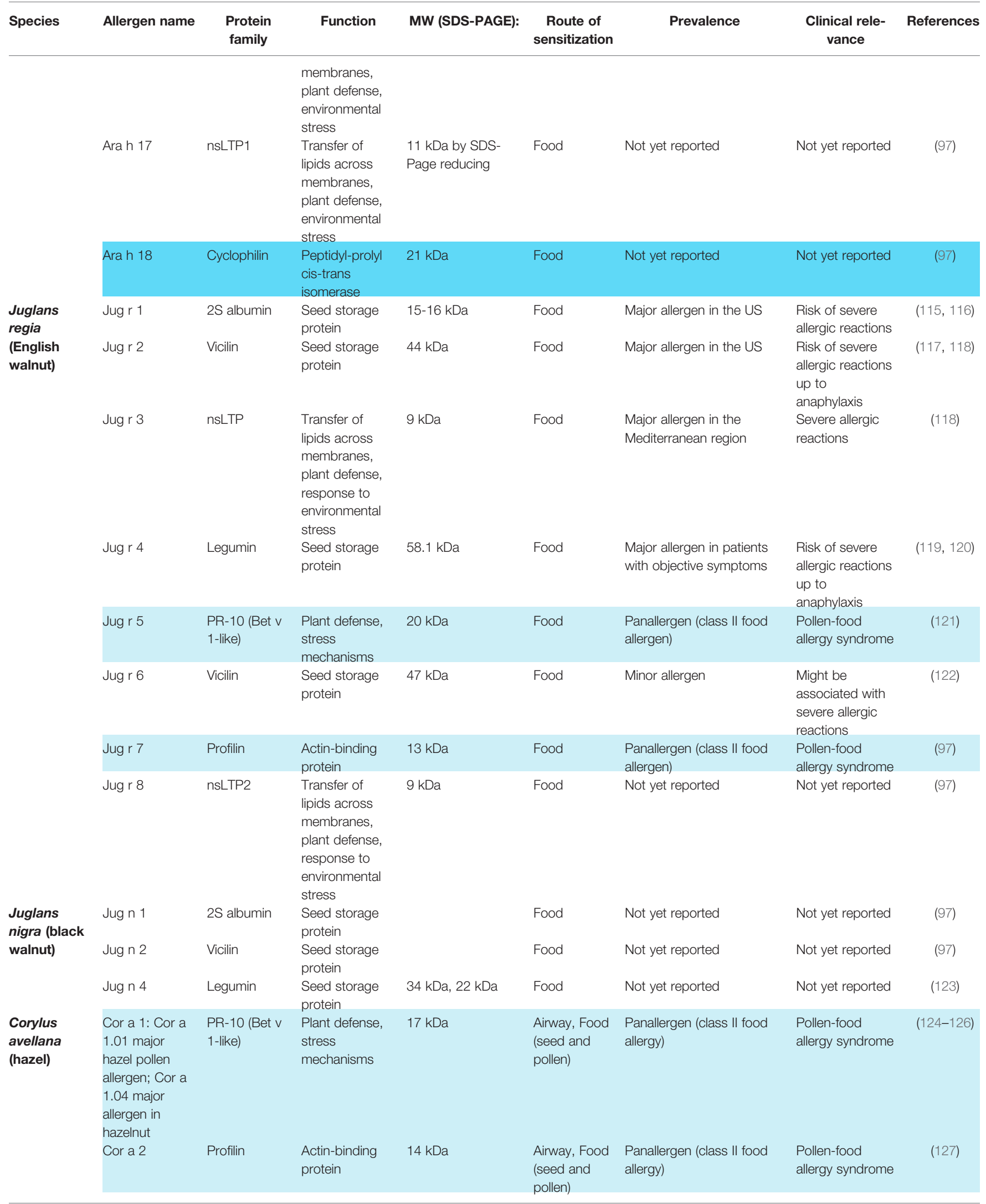


TABLE 2 | Continued

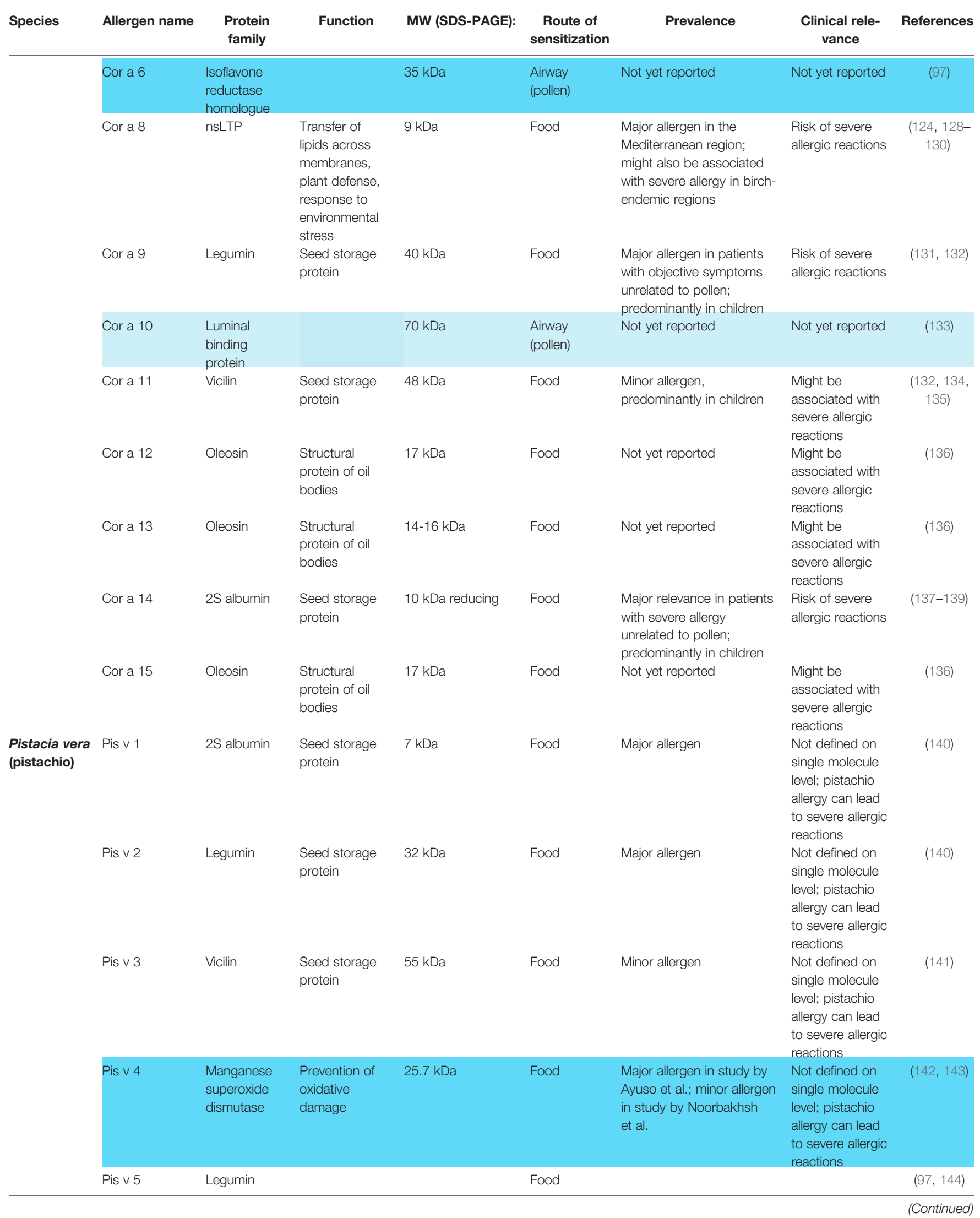


TABLE 2 | Continued

\begin{tabular}{|c|c|c|c|c|c|c|c|c|}
\hline Species & Allergen name & $\begin{array}{l}\text { Protein } \\
\text { family }\end{array}$ & Function & MW (SDS-PAGE): & $\begin{array}{c}\text { Route of } \\
\text { sensitization }\end{array}$ & Prevalence & $\begin{array}{l}\text { Clinical rele- } \\
\text { vance }\end{array}$ & References \\
\hline & & & $\begin{array}{l}\text { Seed storage } \\
\text { protein }\end{array}$ & $\begin{array}{l}36 \mathrm{kDa} \text { (acidic } \\
\text { subunit) }\end{array}$ & & $\begin{array}{l}\text { Minor allergen according to } \\
\text { Willison et al. (referring to } \\
\text { unpublished data) }\end{array}$ & $\begin{array}{l}\text { Not defined on } \\
\text { single molecule } \\
\text { level; pistachio } \\
\text { allergy can lead } \\
\text { to severe allergic } \\
\text { reactions }\end{array}$ & \\
\hline \multirow[t]{3}{*}{$\begin{array}{l}\text { Anacardium } \\
\text { occidentale } \\
\text { (cashew) }\end{array}$} & Ana o 1 & Vicilin & $\begin{array}{l}\text { Seed storage } \\
\text { protein }\end{array}$ & $50 \mathrm{kDa}$ & Food & Major allergen & $\begin{array}{l}\text { Not defined on } \\
\text { single molecule } \\
\text { level; cashews } \\
\text { are associated } \\
\text { with severe } \\
\text { allergic reactions }\end{array}$ & $(145)$ \\
\hline & Ana $\circ 2$ & Legumin & $\begin{array}{l}\text { Seed storage } \\
\text { protein }\end{array}$ & $55 \mathrm{kDa}$ & Food & Major allergen & $\begin{array}{l}\text { Not defined on } \\
\text { single molecule } \\
\text { level; cashews } \\
\text { are associated } \\
\text { with severe } \\
\text { allergic reactions }\end{array}$ & $(146)$ \\
\hline & Ana o 3 & 2S albumin & $\begin{array}{l}\text { Seed storage } \\
\text { protein }\end{array}$ & $14 \mathrm{kDa}$ & Food & Major allergen & $\begin{array}{l}\text { Not defined on } \\
\text { single molecule } \\
\text { level; cashews } \\
\text { are associated } \\
\text { with severe } \\
\text { allergic reactions }\end{array}$ & $(147)$ \\
\hline \multirow[t]{6}{*}{$\begin{array}{l}\text { Prunus } \\
\text { dulcis } \\
\text { (almond) }\end{array}$} & Pru du 3 & nsLTP1 & $\begin{array}{l}\text { Transfer of } \\
\text { lipids across } \\
\text { membranes, } \\
\text { plant defense, } \\
\text { response to } \\
\text { environmental } \\
\text { stress }\end{array}$ & $9 \mathrm{kDa}$ & Food & $\begin{array}{l}\text { LTPs usually prevalent in } \\
\text { Mediterranean region }\end{array}$ & $\begin{array}{l}\text { Might lead to } \\
\text { severe allergic } \\
\text { reactions, based } \\
\text { on allergenicity } \\
\text { of other nsLTPs }\end{array}$ & (97) \\
\hline & Pru du 4 & Profilin & $\begin{array}{l}\text { Actin-binding } \\
\text { protein }\end{array}$ & $14 \mathrm{kDa}$ & $\begin{array}{l}\text { Airway } \\
\text { (pollen) }\end{array}$ & $\begin{array}{l}\text { Panallergen (class II food } \\
\text { allergy) }\end{array}$ & $\begin{array}{l}\text { Pollen-food } \\
\text { allergy syndrome }\end{array}$ & $(148)$ \\
\hline & Pru du 5 & $\begin{array}{l}60 \text { s acidic } \\
\text { ribosomal } \\
\text { protein. P2 }\end{array}$ & & $10 \mathrm{kDa}$ & $\begin{array}{l}\text { Airway } \\
\text { (pollen) }\end{array}$ & $\begin{array}{l}\text { Possibly major allergen, but } \\
\text { more studies needed }\end{array}$ & Not yet reported & $(149)$ \\
\hline & Pru du 6 & Legumin & $\begin{array}{l}\text { Seed storage } \\
\text { protein }\end{array}$ & $\begin{array}{l}60 \mathrm{kDa}(360 \mathrm{kDa} \\
\text { hexamer) }\end{array}$ & Food & Major allergen & $\begin{array}{l}\text { Might be a } \\
\text { specific marker } \\
\text { for almond } \\
\text { allergy }\end{array}$ & $(150-152)$ \\
\hline & Pru du 8 & $\begin{array}{l}\text { Antimicrobial } \\
\text { seed storage } \\
\text { protein }\end{array}$ & $\begin{array}{l}\text { Seed storage } \\
\text { protein }\end{array}$ & $31 \mathrm{kDa}$ & Food & Not yet reported & Not yet reported & (153) \\
\hline & Pru du 10 & $\begin{array}{l}\text { Mandelonitrile } \\
\text { lyase } 2\end{array}$ & & $60 \mathrm{kDa}$ & Food & Not yet reported & Not yet reported & $(97)$ \\
\hline \multirow[t]{2}{*}{$\begin{array}{l}\text { Bertholletia } \\
\text { excelsa } \\
\text { (Brazil nut) }\end{array}$} & Ber e 1 & $2 S$ albumin & $\begin{array}{l}\text { Seed storage } \\
\text { protein }\end{array}$ & 9 kDa & Food & Major allergen & $\begin{array}{l}\text { Risk of severe } \\
\text { allergic reactions } \\
\text { up to } \\
\text { anaphylaxis }\end{array}$ & $(154,155)$ \\
\hline & Ber e 2 & Legumin & $\begin{array}{l}\text { Seed storage } \\
\text { protein }\end{array}$ & 29 kDa & Food & Major allergen & $\begin{array}{l}\text { More studies } \\
\text { needed for } \\
\text { clinical evaluation }\end{array}$ & $(156,157)$ \\
\hline \multirow[t]{3}{*}{$\begin{array}{l}\text { Carya } \\
\text { illinoinensis } \\
\text { (pecan) }\end{array}$} & Car i 1 & 2S albumin & $\begin{array}{l}\text { Seed storage } \\
\text { protein }\end{array}$ & $16 \mathrm{kDa}$ & Food & Major allergen & $\begin{array}{l}\text { More studies on } \\
\text { single-molecule } \\
\text { level needed for } \\
\text { clinical evaluation }\end{array}$ & (158) \\
\hline & Car i 2 & Vicilin & $\begin{array}{l}\text { Seed storage } \\
\text { protein }\end{array}$ & $55 \mathrm{kDa}$ & Food & Minor allergen & $\begin{array}{l}\text { More studies on } \\
\text { single-molecule } \\
\text { level needed for } \\
\text { clinical evaluation }\end{array}$ & (159) \\
\hline & Car i 4 & Legumin & $\begin{array}{l}\text { Seed storage } \\
\text { protein }\end{array}$ & & Food & Major allergen & $\begin{array}{l}\text { More studies on } \\
\text { single-molecule }\end{array}$ & $(160)$ \\
\hline
\end{tabular}


TABLE 2 | Continued

\begin{tabular}{|c|c|c|c|c|c|c|c|c|}
\hline Species & Allergen name & $\begin{array}{l}\text { Protein } \\
\text { family }\end{array}$ & Function & MW (SDS-PAGE): & $\begin{array}{c}\text { Route of } \\
\text { sensitization }\end{array}$ & Prevalence & $\begin{array}{l}\text { Clinical rele- } \\
\text { vance }\end{array}$ & References \\
\hline & & & & $\begin{array}{l}\text { Subunit of } \\
\text { hexameric protein: } \\
55.4 \mathrm{kDa}\end{array}$ & & & $\begin{array}{l}\text { level needed for } \\
\text { clinical evaluation }\end{array}$ & \\
\hline \multirow[t]{2}{*}{$\begin{array}{l}\text { Macadamia } \\
\text { integrifolia } \\
\text { (macadamia) }\end{array}$} & Mac i 1 & Vicilin & $\begin{array}{l}\text { Seed storage } \\
\text { protein }\end{array}$ & $50 \mathrm{kDa}$ & Food & Not yet reported & $\begin{array}{l}\text { More studies on } \\
\text { single-molecule } \\
\text { level needed for } \\
\text { clinical evaluation }\end{array}$ & $(97)$ \\
\hline & Mac i 2 & Legumin & $\begin{array}{l}\text { Seed storage } \\
\text { protein }\end{array}$ & $\begin{array}{l}60 \mathrm{kDa} \text { non } \\
\text { reducing; } 20 \mathrm{kDa} \\
\text { and } 40 \mathrm{kDa} \\
\text { reducing }\end{array}$ & Food & Not yet reported & $\begin{array}{l}\text { More studies on } \\
\text { single-molecule } \\
\text { level needed for } \\
\text { clinical evaluation }\end{array}$ & $(97)$ \\
\hline
\end{tabular}

Confirmed (light blue) and putative (dark blue) cross-reactive class I/ allergens are highlighted.

indicating it is of minor clinical relevance $(117,122)$. Interestingly, cross-reactivity has been shown between Jug r 6 and homologues from pistachio, sesame and hazelnut, which, however, did not apply for Jug r 2 (122).

\subsubsection{Hazelnut}

So far, 11 allergens from common hazel (Corylus avellana) are registered in the WHO/IUIS database (97) (Table 2).

Sensitization to the nsLTP, Cor a 8 predominantly occurs in patients from the Mediterranean region and has been associated with severe allergic reactions $(128,130)$. However, also in birchendemic regions, sensitization to Cor a 8 was found in children who had objective reactions during DBPCFC (129). Pastorello et al. reported IgE reactivity to Cor a 8 in patients with a history of anaphylactic reactions to hazelnuts and demonstrated inhibition of IgE binding to Cor a 8 by the purified Pru p 3 (124).

Severe allergic reactions unrelated to pollen allergy have also been reported from patients with sensitization to the $11 \mathrm{~S}$ globulin Cor a 9 and the 7S globulin Cor a 11 (132). IgE reactivity to Cor a 9 was detected in 12 of 14 patients with a history of systemic reactions to hazelnuts (131). In hazelnutallergic patients from birch-endemic regions, age-related differences regarding the sensitization to Cor a 9 were observed (126). In total, $65 \%$ of pre-school children and $50 \%$ of schoolchildren, but only $17 \%$ of adults with systemic reactions were sensitized to Cor a 9. In a study by Lauer et al., IgE sensitization to Cor a 11 was observed in less than $50 \%$ of 65 hazelnut-allergic patients and the allergen demonstrated significantly lower biological activity in comparison to Cor a 1, suggesting that Cor a 11 is a less relevant hazelnut allergen (134). Similar to Cor a 9, in birch-endemic regions, sensitization to Cor a 11 is age-dependent and is recognized predominantly by children with objective symptoms (135).

The 2S albumin Cor a 14 was first identified in 2010 (137). In a study by Faber et al., IgE reactivity of hazelnut-allergic patients to Cor a 14 was analyzed in different age groups, revealing that Cor a 14 was predominantly recognized in pre-school $(18 / 20)$ and school-aged children (8/10) (139). In Dutch patients with hazelnut allergy, sensitization to Cor a 14 and Cor a 9 was shown to be highly specific for predicting more severe hazelnut allergy (138). Similar results were obtained in another study that examined the role of component resolved diagnostics for the prediction of clinical allergy in hazelnut-allergic children (170). Specific IgE to Cor a 14 was found to be reliable for the discrimination between patients with clinical reactivity and those that were nonreactive.

The hazelnut oleosins Cor a 12, Cor a 13 and Cor a 15 might be associated with severe allergic reactions $(136,171)$. However, more studies are needed to establish their clinical relevance. In Europe, sensitization to Cor a 12 in patients with reported reactions to hazelnuts ranged from 10 to $25 \%$ and appeared to be more frequent in children than adults (172). The clinical relevance of Cor a 6, a isoflavone reductase-related protein, and Cor a 10 a luminal binding protein with possible pollen crossreactivity remains to be determined.

\subsubsection{Pistachio}

Five allergens from Pistacia vera (Pis v 1, Pis v 2, Pis v 3, Pis v 4 and Pis v 5) have been officially approved (97) (Table 2). The sensitization profile of patients with pistachio allergy varies significantly across Europe, indicating age-related, demographic and ethnic differences among the population (56, $60,63)$. The clinical relevance of individual pistachio allergens has not been investigated in detail, but it has been shown that pistachio allergy can lead to severe allergic reactions (173).

Ahn et al. reported IgE reactivity in the serum of 19 out of 28 pistachio-allergic patients to a $7 \mathrm{kDa} 2 \mathrm{~S}$ albumin, which was designated Pis v 1 . Moreover, 14 out of 28 patients showed IgE binding to the legumin-like protein Pis v 2 (140). These allergens were further identified as homologous of the cashew allergens Ana o 3 and Ana o 2, respectively. The cashew tree belongs just like pistachio to the Anacardiaceae family, which explains the high structural similarity of the proteins and indicates cross-reactivity.

IgE sensitization to the 7S globulin Pis $v 3$ was shown in 7 of 19 patients who had a history of allergic reactions to pistachio and/or cashew (141). The patients with IgE reactivity to rPis v 3 also reacted to rAna o 1 from cashew nut.

In 16 out of 27 sera from pistachio-allergic patients, IgE reactivity to a manganese superoxide dismutase (MnSOD)-like protein, designated Pis v 4, from pistachio was detected (142). MnSOD-like proteins are known as cross-reactive respiratory allergens (174) and hence Pis v 4 may be considered as a class II 
food allergen. In 2010, Noorbakhsh et al. reported the expression and purification of recombinant Pis $\mathrm{v}$ 4, which exhibited IgE reactivity in 10 of 25 patients (143). Moreover, cross-reactivity with other MnSODs was suggested by the authors.

Pis v 5 is another legumin of pistachio nut, but little is known about the clinical relevance of this protein (97). However, it was described as minor pistachio allergen by Willison et al., referring to unpublished data that reported IgE reactivity in 10 out of 28 patients (144).

\subsubsection{Cashew}

Currently, three cashew (Anacardium occidentale) allergens are registered in the database of the WHO/IUIS (97) (Table 2). The vicilin Ana o 1, the legumin Ana o 2 and the $2 \mathrm{~S}$ albumin Ana o 3 are listed as the major allergens of cashew nut.

Wang et al. reported IgE reactivity to rAna o 1 in 10 out of 20 patients with a history of severe reactions to cashew (145). IgE reactivity to rAna o 2 was shown in 13 out of 21 cashew-allergic patients (146). Robotham et al. detected IgE reactivity to rAna o 3 in 21 of 26 patients with cashew nut allergy (147). Crossreactivity between the botanically related cashew and pistachio nuts, both members of the Anacardiaceae family, has been observed in several studies $(64,141,175)$.

\subsubsection{Almond}

So far 6 allergens from Prunus dulcis (Pru du 3, Pru du 4, Pru du 5, Pru du 6, Pru du 8 and Pru du 10) have been officially recognized by the WHO/IUIS (97) (Table 2).

Pru du 3 belongs to the nsLTP family, which is usually associated with high allergenic activity and cross-reactivity between members of the Rosaceae family, mainly in the Mediterranean region $(176,177)$. However, large clinical studies evaluating the prevalence of IgE sensitization to Pru du 3 in almond-allergic patients from different regions are needed.

The 60s acidic ribosomal protein P2 has been identified as Pru du 5 , and IgE reactivity to a recombinant variant of the protein was shown in 4 of 8 almond-sensitized patients (149). Acid ribosomal proteins have been identified in molds as allergens and it may therefore be considered that this allergen may represent a class II food allergen (178).

Reactivity to recombinant variants of the amandin Pru du 6, Pru du 6.01 and Pru du 6.02, was seen in 9 of 18 and 5 of 18 almond-allergic patients, respectively, while only 4 of the tested patients showed IgE reactivity to both isoforms (151). Kabasser et al. suggested that Pru du 6 might be a specific marker for almond allergy since 16 of 18 almond-allergic patients showed IgE reactivity to the allergen (152). Moreover, positive sIgE to Pru du 6 provided a specificity of $78 \%$ and a sensitivity of $83 \%$ for almond allergy, while at the same threshold level, the detection of sIgE to almond extract significantly lacked specificity (33\%). In comparison, Pru du 8 and Pru du 10 had specificities of $100 \%$ and $61 \%$ but were less sensitive (41\% and $67 \%$ ) (152). The antigenicity of almond amandin does not seem to be influenced by roasting, blanching or autoclaving, indicating high protein stability $(179,180)$.

In 2019, Che et al. reported that Pru du 8 might be a member of a novel food allergen family with antimicrobial properties and demonstrated IgE reactivity against $\mathrm{rPru}$ du 8 in 6 of 18 patients (153).

\subsubsection{Brazil Nut}

To this date, the $2 \mathrm{~S}$ albumin Ber e 1 and the $11 \mathrm{~S}$ globulin Ber e 2 from Brazil nut (Bertholletia excelsa) have been registered in the allergen data base (97) (Table 2).

Pastorello et al. reported that each of 11 patients with a history of anaphylaxis after the consumption of Brazil nut, showed $\operatorname{IgE}$ reactivity to a $2 \mathrm{~S}$ albumin, implying that it represents a major allergen from Brazil nut (154). Rayes et al. suggested improvement of allergy diagnosis by measurement of IgE to recombinant Ber e 1, which provides higher sensitivity without loss of specificity compared to whole nut extract (181). Beyer et al. reported the identification of a $11 \mathrm{~S}$ globulin, designated Ber e 2, as another major allergen from Brazil nut, showing IgE reactivity to the native protein in $56 \%$ and the recombinant variant in $44 \%$ of sera from Brazil nut-sensitized patients $(\mathrm{n}=27)(157)$.

\subsubsection{Pecan}

Three proteins from Carya illinoinensis, the $2 \mathrm{~S}$ albumin Car i 1, the vicilin Car i 2 and the legumin Car i 4 have been officially approved as allergens (97) (Table 2).

In 2011, the $2 \mathrm{~S}$ albumin Car i 1 was characterized and $\operatorname{IgE}$ binding to recombinant Car i 1 was detected in 22 of 28 patients with pecan allergy (158). The same study showed that pecan and walnut extracts inhibited IgE binding to recombinant Car i 1, indicating strong cross-reactivity with homologous proteins from these nuts. In 2016, Zhang et al. reported that 6 out of 25 patients with DBPCFC-confirmed pecan allergy, showed IgE reactivity to pecan vicilin Car i 2 (159). In a study by Sharma et al., an $11 \mathrm{~S}$ globulin from pecan, designated Cari i 4, was recognized by $\operatorname{IgE}$ from 16 out of 28 patients with pecan allergy (160). Furthermore, extracts from pecan as well as walnut inhibited IgE binding to rCar i 4, suggesting cross-reactivity with legumins from other tree nuts.

\subsubsection{Macadamia}

To date, 2 allergens from macadamia nut (Macadamia integrifolia), the vicilin Mac i 1 and the legumin Mac i 2, are included in the allergen list of the WHO/IUIS Allergen Nomenclature Sub-committee (97) (Table 2).

In a study by Sutherland et al., IgE reactivity to a $17.4 \mathrm{kDa}$ protein from macadamia was shown in the serum of a patient that had experienced anaphylaxis after consumption of a cake made with macadamia meal (182). Herbst et al. reported IgE reactivity to a macadamia protein of $45 \mathrm{kDa}$ and, under nonreducing conditions, to another protein of $12 \mathrm{kDa}$ (183). Recently, Ehlers et al. reported IgE recognition of vicilin-like antimicrobial peptides in 24 of 82 nut-allergic patients, including 3 patients with a history of systemic reactions to macadamia nut (184). According to available data, measurement of specific IgE to macadamia nut does not always predict clinical allergy and might lead to false-negative results $(185,186)$. However, single allergen molecules of macadamia nut for component resolved diagnosis are lacking and it must be considered that macadamia 
extracts might not contain all relevant allergens and thus provide low diagnostic sensitivity (186). Therefore, the identification and characterization of macadamia proteins with established allergenic potential is urgently needed. Possible cross-reactivity between macadamia and hazelnut has been suggested $(182,183)$.

\subsection{Clinically Relevant Panallergens to $\mathrm{Be}$ Considered as Class II Food Allergens}

In peanuts, one of the most relevant panallergens is the Bet $\mathrm{v} 1$ like homologue Ara h 8, which is of major importance in patients from birch-endemic regions where allergic reactions to peanuts can be strongly associated with sensitization to birch pollen (94, 104, 109). Similarly, IgE reactivity to the profilin Ara h 5 is associated with previous sensitization to pollen (106). In walnut, the pathogenesis-related protein (PR-10) Jug r 5 is associated with IgE cross-reactivity between homologous allergens from different plant sources and of minor relevance for patients with primary walnut allergy (121). The Bet v 1-like Cor a 1 and the profilin Cor a 2 are cross-reactive allergens of hazelnut and sensitization to these allergens is typically seen in birch-endemic regions $(50,125$, 127). Both allergens are expressed in hazelnut as well as in hazel pollen. The profilin Pru du 4 is a minor allergen of almond and cross-reactivity with profilins from grass pollen was reported (148). It is quite likely that additional "food allergens" (Table 2, light blue) will be identified for which sensitization occurs by respiratory allergen sources and symptoms of food allergy will be low because the allergens are not heat stable and/or become easily digested and then lose their allergenic activity. Ara h 18, Cor a 6, Pis v 4 and Pru du 5 are possible candidates and there may be more discovered in the future (Table 2 , dark blue). IgE reactivity to the class II nut allergens is not due to genuine nut sensitization and symptoms caused by these allergens may be treated by AIT directed to the originally sensitizing respiratory allergens.

\section{DIAGNOSIS OF NUT ALLERGY}

Diagnosis of nut allergies usually starts with the evaluation of the medical history of the patient. While in the past, diagnosis was mainly achieved by allergen extract-based tests (SPT, OFC), these are increasingly being replaced by modern molecular techniques using specific allergen molecules (Figure 3) (187). Figure 3 compares traditional allergen extract-based diagnosis for nut allergy with modern molecular allergy diagnosis. Traditional extract-based diagnosis uses allergen extracts prepared from the allergen sources for serology and provocation testing in conjunction with the clinical history to determine food which can elicit allergic reactions. Molecular allergy diagnosis is based on IgE serology to a broad panel of defined allergen molecules in combination with the clinical history. In this pathway provocation testing is reduced and usually only performed if necessary to confirm clinically relevant allergy if this cannot be determined by molecular testing and medical history. Molecular testing offers high precision regarding the identification of the culprit allergen molecules is fast and helps to reduce provocation testing which can give rise to severe reactions (187).

\subsection{Food Challenges}

Double-blind, placebo-controlled oral food challenge is still a common procedure for food allergy diagnosis, although in the case of strong clinical suspicion, this is usually avoided. Generally, it is recommended that DBPCFC is performed in a standardized procedure under consideration of several patientrelated and procedure-related parameters (188, 189). Nevertheless, it must be taken into account that oral food challenges (OFC) bear the risk of potentially fatal anaphylaxis during the procedure (43). This applies particularly to nuts,

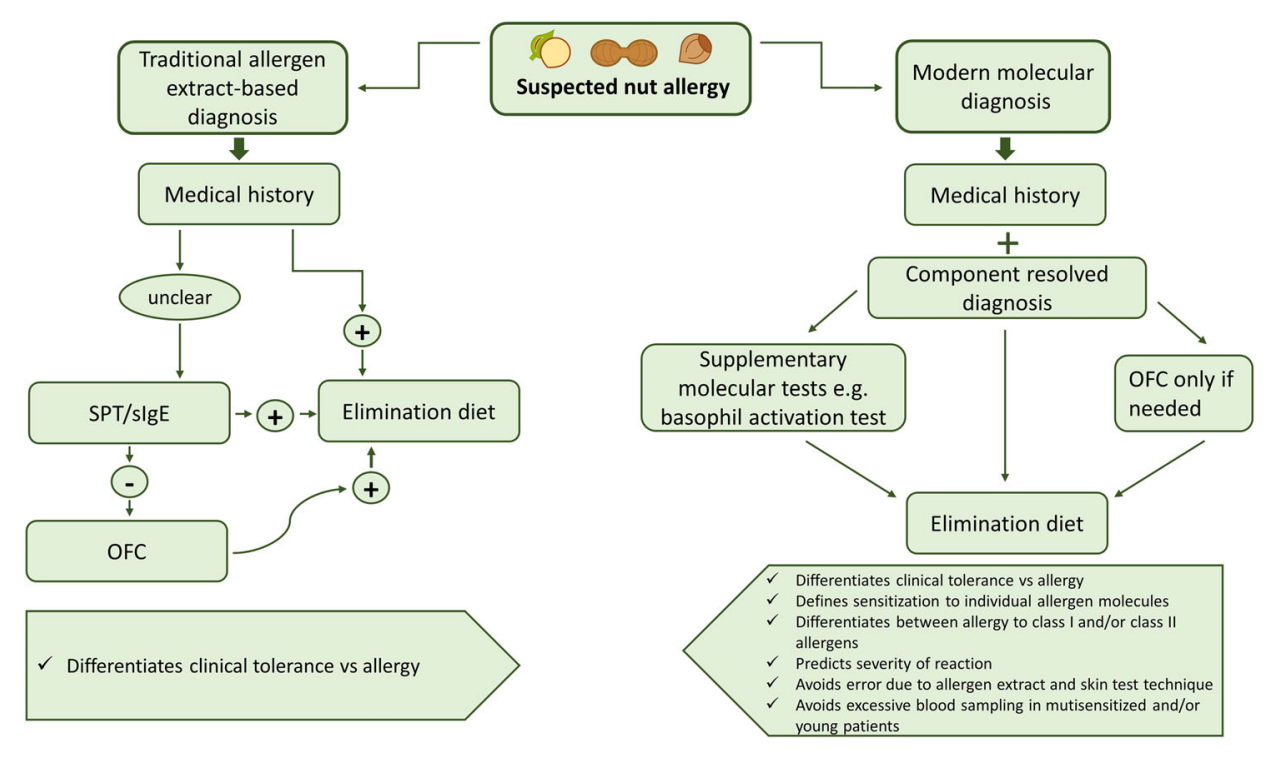

FIGURE 3 | Overview of traditional allergen extract-based nut allergy diagnosis in comparison with modern molecular diagnosis. 
which are among the most common foods causing anaphylaxis (5). In recent studies, lip dose challenges (LDC), using fresh nuts or nut paste, were suggested as a supplement for oral challenges for nut allergy diagnosis $(44,190)$. LDC might be performed as a preliminary test to an OFC but currently cannot replace the latter. However, LDC, in combination with modern molecular diagnostic, might reduce the need for OFC in the future.

\subsection{Skin Tests}

In principle, two types of skin tests can be performed for diagnostics purposes. Skin prick testing measures the induction of mast cell degranulation caused by cross-linking of IgE bound to the high affinity IgE receptor (FceRI) (191) whereas atopy patch testing (APT) detects allergen-specific $\mathrm{T}$ cell activation even in the absence of IgE-mediated effects (191, 192). Accordingly, SPT may be considered as surrogate test for IgEmediated immediate allergic inflammation and APT as surrogate test for chronic, T cell-mediated allergic inflammation. SPT and the detection of food-specific serum IgE with allergen extracts have been traditionally used for allergy diagnosis but have major weaknesses. First of all, these tests are performed with poorly defined allergen extracts and hence do not identify the sensitizing allergen molecules (193). Second, both methods cannot be used to predict clinical sensitivity with certainty because the extent to which digestion affects allergenic activity cannot be measured with these methods. Several authors suggested that the use of fresh food might increase test sensitivity $(194,195)$. Therefore, food challenge tests are still recommended despite the associated risk factors.

\subsection{Molecular Allergy Diagnosis}

Molecular allergy diagnosis is based on the use of purified allergen molecules, mainly recombinant allergens, to determine the IgE sensitization profile of allergic patients (45). There are also attempts to improve the diagnosis of nut allergy by combining different forms of allergen extracts-based diagnosis. For example, it has been shown that prediction of clinical reactivity to pistachio and cashew was improved by SPT in combination with measurement of sIgE (196). However, nowadays native purified or recombinant single allergen molecules are increasingly replacing conventional extracts in in vitro diagnostics. Molecular tests that allow the detection of specific IgE antibodies to individual allergen molecules are also known under the term component-resolved diagnostics (CRD) (197). For peanut allergy, it was demonstrated that by measuring Ara h 2specific IgE, the diagnostic accuracy could be considerably improved (198-201). When measured together, sIgE reactivity to Ara h 6 and Ara h 2 was shown to be predictive for severe peanut allergy (103). For the prediction of positive outcomes of food challenges in children, it was demonstrated that Ara h 2-specific IgE levels of $14.4 \mathrm{kU}_{\mathrm{A}} / \mathrm{L}$ and Cor a 14-specific IgE levels of $47.8 \mathrm{kU}_{\mathrm{A}} /$ $\mathrm{L}$ had an estimated probability of $90 \%$ for predicting a positive peanut or hazelnut challenge (202). In another study, Cor a 14specific IgE levels of 0.5 and $1.0 \mathrm{kU}_{\mathrm{A}} / \mathrm{L}$ had a probability of $50 \%$ and $95 \%$ to predict clinical reactivity to hazelnut in sensitized patients, respectively (170). Moreover, it was shown that measurement of sIgE levels for Cor a 9 in hazelnut-sensitized patients might improve the diagnostic accuracy for the prediction of hazelnut allergy in
Japanese children (203). For cashew it was found that sIgE to individual allergen molecules from cashew nut had a predictive value for the diagnosis of clinical allergy (204-206). Measurement of Jug $\mathrm{r}$ 1-specific IgE was suggested for the prediction of walnut allergy in children due to improved clinical specificity in comparison with IgE to walnut extracts (207).

Several assays have been developed for the detection of serum IgE to either a single allergen analyte (singleplex assay) or various allergens at a time (multiplex assay) (187, 208, 209). The availabilities of single allergens and advanced microarray technology have made it possible to obtain a quick insight into the sensitization profile of a patient (210). In order to enable quantitative conversion between different multiplex IgE testplatforms for nut allergens, statistical models have been established recently (211). For the European MeDALL research project, an allergen chip with 170 allergen molecules, including natural purified and recombinant allergens from almond, cashew, pistachio and peanut, was developed which could be used even for dried blood samples (212). Recently, a study showed moderate agreement of microarray-based analysis in comparison with clinical diagnosis but high sensitivity of the microarray was seen for tree nuts (213). Moreover, the microarray results for tree nuts correlated with SPT results, promising a superior role of component resolved diagnostic for nut allergies in the future.

Another interesting approach for in vitro allergy diagnosis of nut allergy is the basophil activation test (BAT). Since the early description of allergen-induced histamine release from basophils (214) and the demonstration of the applicability of basophil activation testing for recombinant allergens (215), basophil activation testing has continuously developed (216). Importantly, basophil activation can discriminate between IgE-reactive antigens with no or poor ability to induce IgE-mediated receptor aggregation from potent allergens which induce basophil activation already at low doses $(32,217)$. Thus basophil activation testing is useful to address a major problem of in vitro allergy diagnostics, i.e., the possibility of false-positive results due to the presence of crossreactive carbohydrate determinants (218). In plants, these IgEbinding carbohydrate structures are usually $\mathrm{N}$-glycans with a core $\alpha$-1,3-linked fucose residue. It is well established that CCDs are responsible for IgE cross-reactivity between a wide range of plant allergens and other unrelated allergen sources (219). Furthermore, the presence of $\mathrm{N}$-glycans in cellulose-based ImmunoCap assays could lead to false-positive results in patients with high levels of CCD-reactive IgE antibodies (220). Possibilities to overcome $\operatorname{IgE}$ reactivity to CCDs are the production of non-glycosylated recombinant allergen molecules or the use of specific CCD inhibitors (221). CCDdirected IgE antibodies seem to have poor biological activity and are not associated with clinical symptoms (222-224). In basophil activation tests, flow cytometry can be used to analyze basophil activation, which, for example can be defined by the upregulation of the lineage-specific basophil marker CD203c together with the degranulation marker CD63 (225) as has been shown for hazelnut allergy (226). Alternatively, rat basophil cell lines transfected with human FceRI can be loaded with serum IgE 
and then stimulated with allergens (227). Basophil activation was found useful for predicting clinical reactions in peanut allergic patients. Glaumann et al. reported that negative basophil allergen threshold sensitivity correlated with negative DBPCFC in children with peanut allergy (228). Moreover, 92\% with positive DBPCFC had positive threshold sensitivity results and increased levels of IgE antibodies to the major peanut allergens Ara h 1, Ara h 2 and Ara h 3. More recently, basophil activation testing was reported to have high accuracy for the diagnosis of peanut and tree nut allergy but it has not been studied if it can be used to differentiate between sensitization to class I and class II food allergens, causing mild and severe systemic anaphylactic reactions, respectively (229).

Basophil activation testing is also a useful tool to investigate the efficacy of AIT for nut allergy by demonstrating the ability of allergen-specific immunoglobulin G (IgG) antibodies to block IgE-mediated immediate allergic reactions $(230,231)$.

\section{ALLERGEN-SPECIFIC IMMUNOTHERAPIES FOR NUT ALLERGIES}

Most of the strategies for treatment and prevention of food allergy and in particular of nut allergy (e.g., allergen avoidance, diet, use of hypoallergenic food products, AIT) are tightly connected with the accurate identification of the culprit allergens. However, some measures like the management of severe acute and chronic inflammation may be achieved by drugs such as epinephrine injection for treatment of acute anaphylactic reactions, immunosuppressive drugs and anti-IgE treatment (232). Besides diet, AIT is the most important form of allergen-specific treatment. The immunological mechanisms underlying AIT include a modified allergen-specific antibody, cellular and cytokine response (233). Besides complex alterations of the cellular and cytokine responses it has become clear that the induction of allergenspecific IgG and perhaps of allergen-specific IgA antibodies which block IgE binding to the allergen and accordingly the IgE antibodymediate pathology is a key mechanism of AIT (234-236). This has been evidenced in clinical studies using molecular approaches for AIT $(237,238)$ and by the demonstration that passive immunization with allergen-specific blocking IgG antibodies is clinically effective (239-241).

\subsection{Current Forms of AIT For Nut Allergy Are Mainly Based on Allergen Extracts and Subcutaneous AIT Is Rarely Used}

Regarding the treatment of respiratory allergy by AIT subcutaneous injection immunotherapy remains to be the most frequently used and effective form of AIT as documented by a large number of clinical studies although a huge effort has been done to promote sublingual immunotherapy (SLIT) in multiple studies $(235,242)$. However, SCIT is more effective than SLIT and patients adherence to SCIT is much better than to SLIT $(235,243)$. Regarding AIT of food allergy it is of note, that there are only few early studies regarding SCIT $(244,245)$ and it seems that due to unfavorable side effect profiles SCIT has not been further pursued for food allergy. Instead, oral immunotherapy (OIT) has been developed for class I food allergens which are resistant to digestion whereas OIT studies for respiratory allergens and class II food allergens which are sensitive to digestion have not been successful (246-248). Another important aspect is that only few attempts were made to introduce molecular forms of AIT for food allergy whereas different forms of molecular AIT have been evaluated for respiratory allergy (235). One possible reason for this could be that many more patients suffer from respiratory allergy than from food allergy and usually new forms of treatment are mainly evaluated for frequently occurring forms of allergy because the costs for the preclinical and clinical development of novel vaccines are high. Accordingly, the majority of AIT trials for food allergy have been performed with allergen extracts and by using the OIT approach.

\subsection{Oral Immunotherapy}

OIT is based on the controlled ingestion of the allergen-causing food, intending to achieve sustained desensitization in the patients. It has been shown that similar as for SCIT, the success of treatment is associated with the development of allergen-specific IgG blocking antibodies which have actually been measured in many of the OIT studies. Table 3 provides and overview of OIT studies (249-279) informing about the number of participants, the study design, clinical and immunological outcomes, side effects and references and/or trial registration numbers which allow to track the studies in the Clinical Trials data base (https://clinicaltrials.gov/). Most of the studies were conducted for peanut allergy whereas OIT studies for tree nut allergies are scarce (Table 3). A study by Andorf et al. (280) is one of the few studies providing evidence for effects of OIT to several different nuts when OIT was combined with antiIgE treatment.

There are methods available for determining major peanut allergens in natural allergen extracts (281) but the precise concentrations of the individual peanut allergens in the natural extracts is not known. Currently, there is no standardized procedure for OIT neither regarding the study design nor are there defined vaccines with known composition. Usually, OIT starts with a dose-escalation day, followed by a buildup phase during which increasing amounts of the allergen are ingested until the maintenance dose is reached. DBPCFC might be performed after a defined food avoidance period to confirm sustained desensitization in the treated subjects. Already in 2009, Jones et al. reported a clinical trial of peanut OIT (249). Since then, the efficacy and safety of peanut OIT have been extensively studied. OIT studies demonstrated successful desensitization and the production of protective IgG4 antibodies but reports of adverse reactions raised safety concerns (267, 269). Adverse reactions affecting the gastrointestinal and respiratory tract during peanut OIT are common (282). To reduce the risk of side effects and to accelerate the desensitization process, the supplementation of OIT with omalizumab, an anti-IgE monoclonal antibody, has been suggested (283-285). The optimal time point to start OIT, treatment duration and length of the maintenance phase are still a matter of debate. With exception of few studies (261, 265, 267-270), most studies involved less than 100 patients and the achieved clinical 


\begin{tabular}{cccccc}
\hline Allergen & $\begin{array}{c}\text { Number of } \\
\text { participant } \\
\text { (age) }\end{array}$ & Study design $\quad$ Protocol summary Clinical outcome & Serological outcome Reported side effects $\quad$ Clinical trial number $\quad$ Ref. \\
\hline
\end{tabular}

(age)

OIT

Peanut: peanut

flour $(50 \%$

protein); for

29 subjects

(1-16 years)

proitional

analysis peanut

extracted from

peanut flour, Ara

h 2 was purified

and protein

concentrations

were

determined by

bicinchoninic

acid assay

Peanut:

23 initial Open-label,

whole crushed subjects (3- randomized

roasted

subjects (3-
14 years); 14

peanuts; $4 \mathrm{~g}$ finished study

whole peanut $=$ protocol (until

$1 \mathrm{~g}$ peanut
Initial dose escalation day - 27 of $29(93 \%)$ reached total • starting at $0.1 \mathrm{mg}$ peanut protein. Dose was

doubled every 30 minutes

up to $50 \mathrm{mg}$. Build-up

phase started with highest

tolerated dose during

initial day escalation.

During build-up phase

daily ingestion of peanut

protein with biweekly

dose increases (by $25 \mathrm{mg}$ )

until $300 \mathrm{mg}$ reached. For

patients that stopped

initial escalation dosing

below $50 \mathrm{mg}$, doses were

doubled every 2 weeks

until $50 \mathrm{mg}$ reached,

followed by increases of

$25 \mathrm{mg}$. After reaching a

daily tolerated dose of

$300 \mathrm{mg}$ peanut protein,

dose was maintained until

OFC. After OFC, doses

were increased until a

daily dose of $1800 \mathrm{mg}$

peanut protein was

reached, provided that

peanut-specific lgE was $>$

$2 \mathrm{kU} / \mathrm{L}$ after 1 year on

maintenance dose.

Evaluation of subjects

every 4 months during

maintenance phase (up to

total duration of 36

months). OFC up to $3.9 \mathrm{~g}$

peanut protein or unti

objective symptoms

appeared.

Participants underwent

DBPCFC with increasing

doses of whole peanut

$(0.03-2 \mathrm{~g})$, equaling

0.0075-0.5 g peanut

protein, which were given

after 36 months without

showing more than mild

symptoms and were thus

considered desensitized. The

other 2 stopped OFC after

$2.1 \mathrm{~g}$ peanut protein.

7 subjects underwent open OFC to peanut protein after

13-22 months of

maintenance dosing; 22

underwent OFC after 4-7

months

5 patients reached $500 \mathrm{mg}$ peanut dose during the

rushed protocol.

Overall, 14 of 22 patients

reached a daily maintenance

dose of at least $500 \mathrm{mg}$ peanut dose of $3.9 \mathrm{~g}$ in OFC

An increase of specific $\lg G$

- Peanut-specific lgG4 levels

- Several inflammatory

At 6 and 12 months FoxP3
Within 4 months, basophil

reactivity at peanut

Symptoms were reported NCT01074840

after $46 \%$ of build-up

concentration of $10 \mu \mathrm{g} / \mathrm{ml} \quad$ doses.

was significantly reduced. During maintenance phase,

Within 3 months, peanut- all subjects experienced

specific IgE levels increased adverse events at some

from an initial median point, which were mostly

concentration of $85.4 \mathrm{kU}_{\mathrm{A}} \mathrm{L} \mathrm{L}$ mild and affected most

to $249.0 \mathrm{kU}$ (L. For all time commonly the upper

points after 18 months (up respiratory tract and the

to 33 months) peanut- skin. Two of the participants

specific lgE levels were

decreased.

received epinephrine once

during home dosing.

levels was observed starting

at 3 months of treatment

and remained high until 24

months, before it returned

to baseline by 33 months.

reached significance at 3

months and increased until

the end of the study.

cytokines/chemokines (IL-1 $\beta$,

IL-5, TNF- $\alpha$, MIP- $1 \beta$, G-CSF

and GM-CSF) were

increased over time

(following peanut stimulation)

T cells increased 1.5 -fold in

peanut-stimulated cells

before returning to baseline

by 20 months.

(249)

In the 14 patients that finished Of 6137 total OIT doses, the study protocol, a $\quad 2.6 \%$ were associated with reduction in the secretion of mild to moderate adverse

No clinical trial number the $\mathrm{O}$, and $I L-2$ at the end etfects. 4 patients stopped ethics committee OIT due to adverse avoidance) was observed and reactions. All of them had 


\begin{tabular}{|c|c|c|c|c|c|c|c|c|}
\hline Allergen & $\begin{array}{c}\text { Number of } \\
\text { participant } \\
\text { (age) }\end{array}$ & Study design & Protocol summary & Clinical outcome & Serological outcome & Reported side effects & Clinical trial number & Ref. \\
\hline $\begin{array}{l}\text { protein; dose of } \\
\text { individual major } \\
\text { allergens not } \\
\text { determined }\end{array}$ & $\begin{array}{l}\text { final } \\
\text { DBPCFC) }\end{array}$ & & $\begin{array}{l}\text { every } 30 \text { minutes (on } 2 \\
\text { different days). In absence } \\
\text { of objective reaction, } \\
\text { patients were challenged } \\
\text { on another day with } 4 \mathrm{~g} \\
\text { whole peanut. The day } \\
\text { after positive DBPCFC } \\
\text { followed a rushed } \\
\text { escalation protocol for } 1 \\
\text { week during which } \\
\text { increasing doses of whole } \\
\text { peanuts were given } 2-4 x \\
\text { a day. The staring dose } \\
\text { was approx. } 1 / 100 \text { of the } \\
\text { reaction eliciting dose } \\
\text { during DBPCFC. In those } \\
\text { starting with more than } 6 \\
\text { mg whole peanuts, doses } \\
\text { were doubled. If starting } \\
\text { point was } 80 \text { mg, doses } \\
\text { were increased by } 20 \% \text {. } \\
\text { Subjects that reached at } \\
\text { least } 500 \text { mg whole } \\
\text { peanut during the rushed } \\
\text { protocol, continued with a } \\
\text { maintenance phase of } 8 \\
\text { weeks. Subjects that did } \\
\text { not reach a dose of } 500 \\
\text { mg peanut continued with } \\
\text { individual long-term build- } \\
\text { up protocol (0-20 months) } \\
\text { during which the individual } \\
\text { tolerated dose (24-400 } \\
\text { mg peanut) was } \\
\text { consumed daily, with } \\
\text { dose increases every } 2-4 \\
\text { weeks until } 500 \text { mg was } \\
\text { reached, followed by a } \\
\text { maintenance phase of } 8 \\
\text { weeks. After } 2 \text { weeks of } \\
\text { peanut avoidance, final } \\
\text { DBPCFC was performed. }\end{array}$ & $\begin{array}{l}\text { whole peanut after a median } \\
\text { of } 7 \text { months and underwent } \\
\text { DBPCFC. } \\
\text { At final DBPCFC, a median } \\
\text { of } 1 \mathrm{~g} \text { peanut was tolerated. } \\
\text { Three patients tolerated } 4 \mathrm{~g} \\
\text { whole peanut. Median } \\
\text { tolerated dose before OIT } \\
\text { was } 0.19 \mathrm{~g} \text { peanut. }\end{array}$ & $\begin{array}{l}\text { seen to be stable in most, but } \\
\text { not all of the patients after } \\
\text { avoidance phase. } \\
\text { An increase in peanut- } \\
\text { specific lgG4 levels was } \\
\text { seen in all patients after OIT. } \\
\text { However, a drop in the } \\
\text { peanut-specific lgG4 level } \\
\text { was detected after } 2 \text { weeks } \\
\text { of avoidance. } \\
\text { Patients that reached } 500 \\
\text { mg peanut had lower } \\
\text { median peanut-specific lgE } \\
\text { levels }\left(9.1 \mathrm{kU} \mathrm{U}_{\mathrm{A}} / \mathrm{L}\right) \text { that those } \\
\text { that tolerated less (212 } \\
\left.\mathrm{kU} \mathrm{A}_{\mathrm{A}} / \mathrm{L}\right) \text {. }\end{array}$ & $\begin{array}{l}\text { reported mild to moderate } \\
\text { asthma before start of the } \\
\text { study. During the rush } \\
\text { protocol, objective allergic } \\
\text { symptoms were associated } \\
\text { with } 25 \text { of } 317 \text { total OIT } \\
\text { doses. }\end{array}$ & & \\
\hline
\end{tabular}




\begin{tabular}{|c|c|c|c|c|c|c|c|c|}
\hline Allergen & $\begin{array}{c}\text { Number of } \\
\text { participant } \\
\text { (age) }\end{array}$ & Study design & Protocol summary & Clinical outcome & Serological outcome & Reported side effects & Clinical trial number & Ref. \\
\hline $\begin{array}{l}\text { Peanut: Peanut } \\
\text { protein } \\
\text { extracted from } \\
\text { defatted peanut } \\
\text { four ( } 50 \% \\
\text { protein); intact } \\
\text { allergen content } \\
\text { in soluble } \\
\text { extract of } \\
\text { roasted peanut } \\
\text { flour } \sim 8 \% \text { Ara h } \\
1 \text { and } ~ 7 \% \\
\text { Ara h } 2\end{array}$ & $\begin{array}{l}\text { Initially } 28 \\
\text { (1-16 years) } \\
\text { participants; } \\
3 \text { withdrew; } \\
16 \text { remained } \\
\text { in peanut OIT } \\
\text { group, } 9 \text { in } \\
\text { placebo } \\
\text { group }\end{array}$ & $\begin{array}{l}\text { Randomized, } \\
\text { placebo- } \\
\text { controlled }\end{array}$ & $\begin{array}{l}\text { Initial day escalation } \\
\text { phase starting with } 0.1 \\
\text { mg peanut protein (or } \\
\text { placebo). Doses were } \\
\text { doubled every } 30 \text { minutes } \\
\text { up to } 6 \text { mg. Build-up } \\
\text { phase started with highest } \\
\text { tolerated dose in initial } \\
\text { escalation. During home- } \\
\text { dosing, subjects ingested } \\
\text { daily doses and attended } \\
\text { build-up visits every two } \\
\text { weeks for approximately } \\
44 \text { weeks. Doses were } \\
\text { increased by } 50-100 \% \\
\text { until } 75 \text { mg and } 25-33 \% \\
\text { until daily maintenance } \\
\text { dose of } 4000 \text { mg was } \\
\text { reached. The } \\
\text { maintenance dose was } \\
\text { consumed daily for one } \\
\text { month, followed by an } \\
\text { OFC at week } 48 \text {. }\end{array}$ & $\begin{array}{l}16 \text { of originally } 19 \text { participants } \\
\text { ( } 84 \%) \text { in the OIT group } \\
\text { reached a maintenance dose } \\
\text { of } 4000 \text { mg and tolerated a } \\
\text { maximum cumulative dose of } \\
5000 \mathrm{mg} \text { peanut protein in } \\
\text { OFC compared to a median } \\
\text { cumulative dose of } 280 \mathrm{mg} \\
\text { peanut protein in the placebo } \\
\text { group. }\end{array}$ & 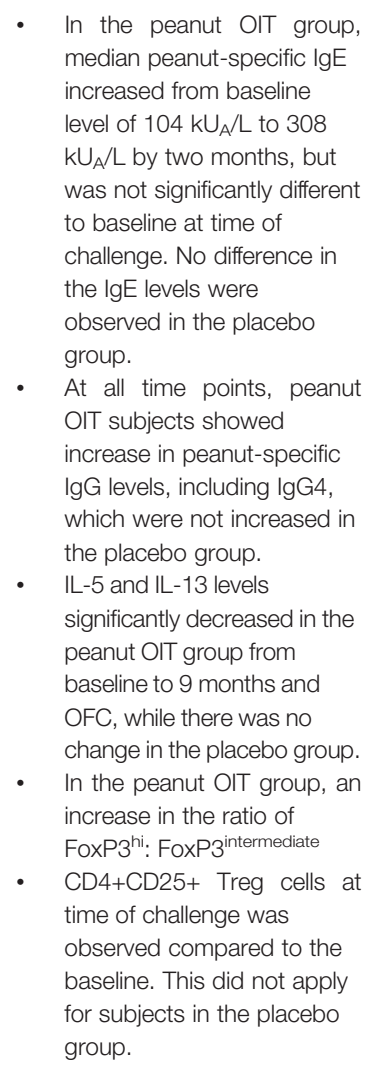 & $\begin{array}{l}\text { During initial dose- } \\
\text { escalation, } 9 \text { of } 19 \text { subjects } \\
\text { in the peanut OIT group had } \\
\text { clinically-relevant adverse } \\
\text { effects and required } \\
\text { antihistamine treatment. Of } \\
\text { those, } 2 \text { additionally } \\
\text { required treatment with } \\
\text { epinephrine. No clinically- } \\
\text { relevant symptoms were } \\
\text { reported in the placebo } \\
\text { group. Of } 407 \text { build-up } \\
\text { doses, } 1.2 \% \text { caused } \\
\text { clinically-relevant symptoms } \\
\text { in the peanut OIT group. } \\
\text { During home dosing, none } \\
\text { of the peanut OIT subjects } \\
\text { required epinephrine. In the } \\
\text { placebo group, one subject } \\
\text { received epinephrine after } \\
\text { reporting symptoms. One } \\
\text { patient in the peanut OIT } \\
\text { group experienced mild- } \\
\text { moderate symptoms after } \\
\text { completing OFC and was } \\
\text { given antihistamine } \\
\text { treatment. In the placebo } \\
\text { group, } 8 \text { subjects } \\
\text { experienced side effects } \\
\text { during OFC, } 3 \text { required } \\
\text { epinephrine treatment. }\end{array}$ & $\begin{array}{l}\text { No clinical trial number } \\
\text { found; study approved } \\
\text { by each institution's } \\
\text { Institutional Review } \\
\text { Board }\end{array}$ & (251) \\
\hline $\begin{array}{l}\text { Peanut: peanut } \\
\text { flour ( } 50 \% \\
\text { protein); dose of } \\
\text { individual major } \\
\text { allergens not } \\
\text { determined }\end{array}$ & $\begin{array}{l}22 \text { subjects } \\
\text { (4-18 years) }\end{array}$ & $\begin{array}{l}\text { Interventional, } \\
\text { open-label }\end{array}$ & $\begin{array}{l}\text { Gradual build-up phase } \\
\text { ( } 56-264 \text { days) with dose } \\
\text { increases every } 2 \text { weeks } \\
\text { up to } 800 \text { mg peanut } \\
\text { protein per day. After } \\
\text { reaching the highest } \\
\text { tolerated dose, subjects } \\
\text { continued with } \\
\text { maintenance for } 30 \text { weeks } \\
\text { during which dose was } \\
\text { ingested on a daily basis. } \\
\text { Patients underwent } \\
\text { DBPCFCs after } 6 \text { weeks }\end{array}$ & $\begin{array}{l}\text { - Primary endpoint was defined } \\
\text { by rate of those passing } \\
\text { challenge after approx. } 6 \\
\text { months. } \\
\text { Of } 22 \text { subjects, } 19 \text { tolerated } \\
\text { build-up to a maximum daily } \\
\text { dose of } 800 \text { mg peanut } \\
\text { protein and successfully } \\
\text { continued maintenance. } \\
\text { After } 6 \text { weeks of maintenance, } \\
19 \text { subjects underwent } \\
\text { OFC to } 2.6 \mathrm{~g} \text { peanut } \\
\text { protein, } 18 \text { ingested the full } \\
\text { dose. } 12 \text { of } 19(63 \%) \text { had }\end{array}$ & $\begin{array}{l}\text { Median peanut-specific IgE } \\
\text { levels increased initially, } \\
\text { before decreasing until } \\
\text { week } 30\left(8.35 \mathrm{kU}_{\mathrm{A}} / \mathrm{L}\right) \\
\text { compared to the baseline } \\
\left(29.7 \mathrm{kU} \mathrm{A}_{\mathrm{A}} / \mathrm{L}\right) \text {. } \\
\text { - } \\
\text { Median peanut-specific IgE } \\
\text { level was significantly lower } \\
\text { at baseline in the } \\
\text { participants that passed } \\
\text { final OFC compared to } \\
\text { those that did not. }\end{array}$ & $\begin{array}{l}\text { At some point during build- } \\
\text { up and maintenance phase, } \\
19 \text { of } 22(86 \%) \text { subjects } \\
\text { experienced adverse } \\
\text { reactions, most commonly } \\
\text { affecting the respiratory or } \\
\text { gastrointestinal tract. }\end{array}$ & NCT01259804 & (252) \\
\hline
\end{tabular}




\begin{tabular}{|c|c|c|c|c|c|c|c|c|}
\hline Allergen & $\begin{array}{l}\text { Number of } \\
\text { participant } \\
\text { (age) }\end{array}$ & Study design & Protocol summary & Clinical outcome & Serological outcome & Reported side effects & Clinical trial number & Ref. \\
\hline & & & $\begin{array}{l}\text { of maintenance and at the } \\
\text { end of the study (week 30). }\end{array}$ & $\begin{array}{l}\text { no symptoms during } \\
\text { challenge, } 7(37 \%) \text { showed } \\
\text { mild to moderate } \\
\text { symptoms. } \\
\text { After } 30 \text { weeks, } 18 \text { subjects } \\
\text { underwent final challenge } \\
\text { with } 6.6 \mathrm{~g} \text { peanut protein. } 14 \\
\text { of } 18 \text { subjects tolerated } \\
\text { challenge without any } \\
\text { symptoms. }\end{array}$ & & & & \\
\hline $\begin{array}{l}\text { Peanut: peanut } \\
\text { flour ( } 50 \% \\
\text { protein); dose of } \\
\text { individual major } \\
\text { allergens not } \\
\text { determined }\end{array}$ & $\begin{array}{l}99 \\
\text { participants } \\
\text { (7-16 years) } \\
\text { were } \\
\text { randomized: } \\
49 \text { in peanut } \\
\text { OIT group } \\
\text { (10 did not } \\
\text { have } \\
\text { DBPCFC } \\
\text { after OIT), } 50 \\
\text { in the peanut } \\
\text { avoiding } \\
\text { control group } \\
\text { (46 included } \\
\text { in primary } \\
\text { analysis) }\end{array}$ & $\begin{array}{l}\text { Randomized, } \\
\text { controlled } \\
\text { (crossover) }\end{array}$ & $\begin{array}{l}\text { Initial gradual up-dosing } \\
\text { phase with biweekly } \\
\text { increases until a target } \\
\text { protein dose of } 800 \mathrm{mg} / \\
\text { day was reached. This } \\
\text { was followed by a } \\
\text { maintenance period with } \\
\text { ingestion of the highest } \\
\text { tolerated dose on a daily } \\
\text { basis to complete } 26 \\
\text { weeks of OIT. } \\
\text { During the 26-week long } \\
\text { first phase, subjects } \\
\text { received peanut OIT or } \\
\text { avoided peanut (control } \\
\text { group). } \\
\text { During the second phase } \\
\text { (crossover), subjects in } \\
\text { the control group received } \\
\text { peanut OIT, followed by } \\
\text { DBPCFC. } \\
\text { Toleration of a cumulative } \\
\text { dose of } 1400 \text { mg peanut } \\
\text { protein during DBPCFC } \\
\text { was considered } \\
\text { desensitization. }\end{array}$ & $\begin{array}{l}\text { Primary endpoint was defined } \\
\text { as desensitization. In the first } \\
\text { phase, } 24 \text { of } 39 \text { (62\%) } \\
\text { participants in the active OIT } \\
\text { group compared to } 0 \text { of } 46 \\
\text { (0\%) in the control group } \\
\text { tolerated a cumulative dose } \\
\text { of } 1400 \text { mg peanut protein in } \\
\text { OFC. } \\
84 \% \text { in the active group } \\
\text { tolerated a daily dose of } 800 \\
\text { mg peanut protein } \\
\text { (secondary outcome). } \\
\text { In the second phase (control } \\
\text { group after OIT), } 91 \% \\
\text { tolerated daily dose of } 800 \\
\text { mg protein and } 54 \% \\
\text { tolerated } 1400 \text { mg in OFC. }\end{array}$ & $\begin{array}{l}\text { Increase in peanut-specific } \\
\text { IgE was measured after } 24 \\
\text { weeks in the OIT group. }\end{array}$ & $\begin{array}{l}\text { Adverse reactions were } \\
\text { reported to the same } \\
\text { extend in both groups } \\
\text { during treatment but were } \\
\text { mostly mild. Oral itching } \\
\text { occurred in } 6.3 \% \text { of all } \\
\text { doses. } 0.41 \% \text { of doses in } \\
22 \% \text { of subjects caused } \\
\text { wheezing which was treated } \\
\text { either with antihistamines } \\
\text { alone or, in one patient, } \\
\text { additionally with epinephrine } \\
\text { on two occasions. } \\
\text { Cutaneous symptoms were } \\
\text { reported after } 0.16 \% \text { of } \\
\text { doses. }\end{array}$ & ISRCTN62416244 & (253) \\
\hline $\begin{array}{l}\text { Peanut: peanut } \\
\text { protein from } \\
\text { partially defatted } \\
\text { peanut flour } \\
\text { (50\% protein); } \\
\text { see (249) }\end{array}$ & $\begin{array}{l}\text { Initially } 39 \\
\text { subjects (1- } \\
16 \text { years) } \\
\text { included; } 24 \\
\text { completed } \\
\text { the protocol }\end{array}$ & Open-label & $\begin{array}{l}\text { End-of-study results of } \\
\text { pilot trial by (249). OIT } \\
\text { protocol by (249), which } \\
\text { was described above. } \\
\text { Extended treatment with a } \\
\text { maximum of } 4000 \mathrm{mg} \\
\text { peanut protein per day for } \\
\text { up to } 5 \text { years. At the end } \\
\text { of the treatment, subjects } \\
\text { underwent two DBPCFCs }\end{array}$ & $\begin{array}{l}12 \text { of } 24 \text { (50\%) subjects } \\
\text { showed treatment success } \\
\text { by reaching } 5000 \mathrm{mg} \\
\text { peanut protein in the } \\
\text { second OFC, } 4 \text { weeks after } \\
\text { stopping OIT, and achieved } \\
\text { sustained } \\
\text { unresponsiveness (primary } \\
\text { endpoint). }\end{array}$ & $\begin{array}{l}\text { Patients that passed final } \\
\text { OFC had lower median IgE } \\
\text { levels specific for peanut } \\
\text { allergens Ara } \mathrm{h} 1 \text { and Ara } \mathrm{h} \\
\text { 2, than those that did not } \\
\text { achieve sustained } \\
\text { unresponsiveness. } \\
\text { In all OIT subjects, a } \\
\text { reduction to below baseline } \\
\text { IgE levels specific for major }\end{array}$ & $\begin{array}{l}6 \text { of the initial } 39 \text { subjects } \\
\text { withdrew due to allergic } \\
\text { side effects (not further } \\
\text { specified). }\end{array}$ & $\begin{array}{l}\text { no clinical trial number } \\
\text { found; ethics approval } \\
\text { obtained through the } \\
\text { Institutional Review } \\
\text { Boards at Duke } \\
\text { University } \\
\text { Medical Center and } \\
\text { University of Arkansas for } \\
\text { Medical Sciences }\end{array}$ & (254) \\
\hline
\end{tabular}




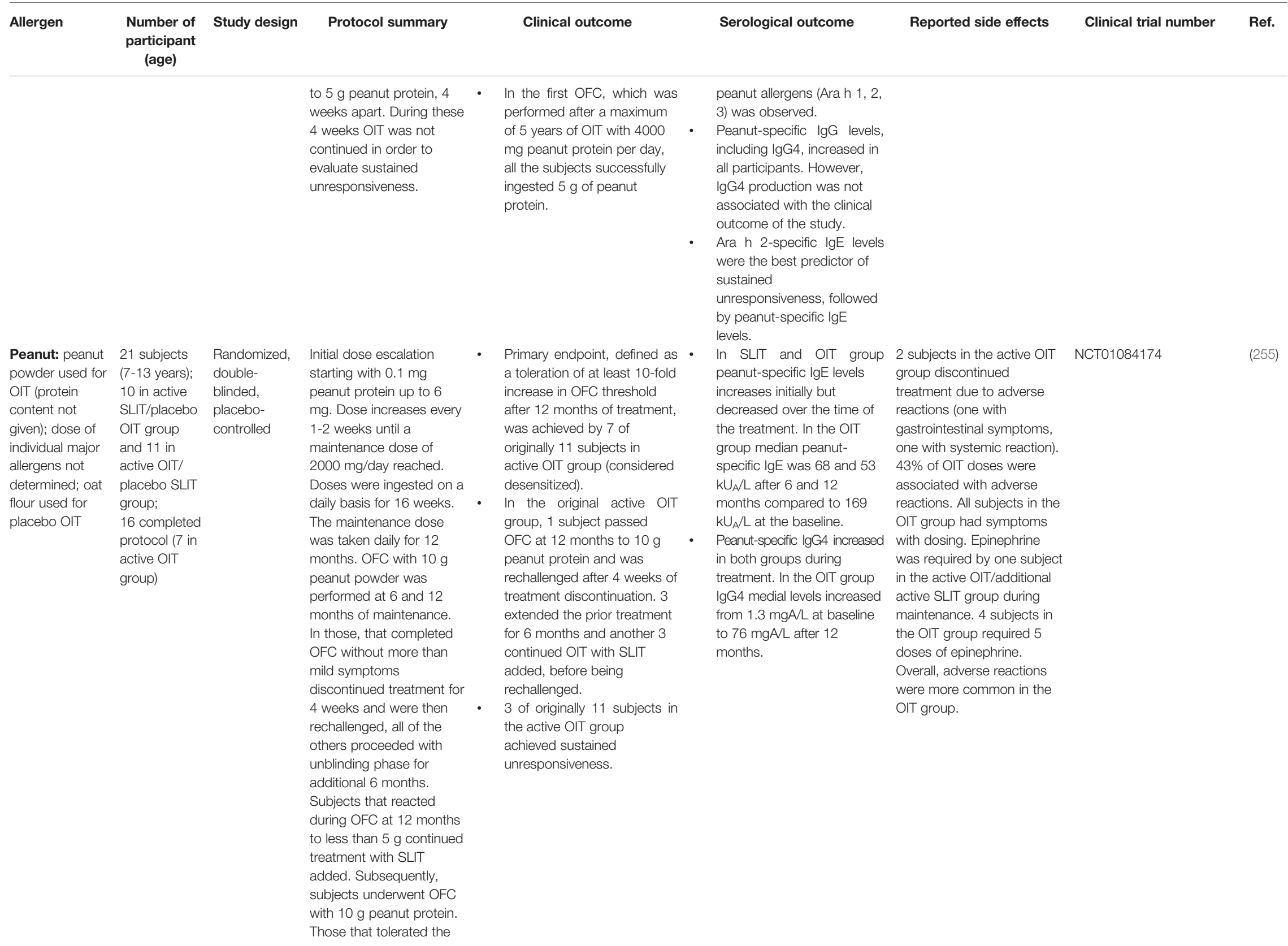




\begin{tabular}{|c|c|c|c|c|c|c|c|c|}
\hline Allergen & $\begin{array}{c}\text { Number of } \\
\text { participant } \\
\text { (age) }\end{array}$ & Study design & Protocol summary & Clinical outcome & Serological outcome & Reported side effects & Clinical trial number & Ref. \\
\hline & & & $\begin{array}{l}\text { treatment (confirmation of } \\
\text { sustained } \\
\text { unresponsiveness) in } \\
\text { those that passed the } \\
\text { challenge. }\end{array}$ & & & & & \\
\hline $\begin{array}{l}\text { Peanut: peanut } \\
\text { margarine made } \\
\text { from roasted } \\
\text { defatted peanut } \\
\text { flour ( } 50 \% \\
\text { protein); dose of } \\
\text { individual major } \\
\text { allergens not } \\
\text { determined }\end{array}$ & $\begin{array}{l}60 \text { subjects } \\
\text { (6-18 years): } \\
39 \text { active OIT, } \\
21 \text { controls } \\
\text { that avoided } \\
\text { peanuts }\end{array}$ & Interventional & $\begin{array}{l}\text { Patients ingested daily } \\
\text { doses of peanut protein } \\
\text { starting with } 0.1 \text { mg and } \\
\text { dose escalations every } 1 \text { - } \\
2 \text { weeks. Build-up phase } \\
\text { (approx. } 8 \text { months) until } \\
\text { maintenance daily dose of } \\
800 \text { mg peanut protein (4 } \\
\text { peanuts) was reached. } \\
\text { DBPCFC was performed } \\
1 \text { month after reaching } \\
\text { maintenance dose. } \\
\text { Afterwards, subjects } \\
\text { ingested } 3-7 \text { weekly } \\
\text { doses of } 4 \text { raw or roasted } \\
\text { peanuts. Patients that } \\
\text { failed challenge continued } \\
\text { with tolerated daily dose. } \\
\text { Median follow-up period } \\
\text { was } 30 \text { months. }\end{array}$ & $\begin{array}{l}33 \text { of } 39 \text { ( } 85 \%) \text { OIT-treated } \\
\text { patients reached daily } \\
\text { maintenance dose ( } 800 \mathrm{mg} \\
\text { peanut protein) in a median } \\
\text { of } 269 \text { days. } \\
26 \text { patients ( } 67 \% \text { in intention- } \\
\text { to-treat analysis) passed } \\
\text { challenge with } 1255 \mathrm{mg} \\
\text { peanut protein ( } 5 \mathrm{~g} \text { peanuts) } \\
\text { (primary endpoint). } \\
\text { - None of the } 21 \text { controls } \\
\text { showed desensitization. } \\
\text { Median follow-up duration } \\
\text { was } 30 \text { months. During the } \\
\text { follow-up phase the median } \\
\text { weekly peanut protein } \\
\text { consumption was } 5600 \mathrm{mg} \text {. }\end{array}$ & $\begin{array}{l}\text { - OIT had no significant effect } \\
\text { on peanut-specific lgE to } \\
\text { Ara } \mathrm{h} 1,2,3,8 \text {, or } 9 \text {. } \\
\text { - Specific IgG4 levels to } \\
\text { peanut, Ara } \mathrm{h} 1,2 \text { and } 3 \\
\text { increased significantly } \\
\text { during the treatment. No } \\
\text { difference was observed in } \\
\text { the avoidance group. } \\
\text { - In } 29 \text { subjects that } \\
\text { continued OIT (1-year } \\
\text { follow-up) peanut-specific } \\
\text { IgE levels to major peanut } \\
\text { allergens (Ara } \mathrm{h} 1,2,3) \\
\text { decreased significantly. }\end{array}$ & $\begin{array}{l}30 \text { of } 39(77 \%) \text { OIT subjects } \\
\text { reported adverse symptoms } \\
\text { during build-up. } 16 \text { of } 39 \\
\text { (41\%) needed additional } \\
\text { antihistamines, } 15 \text { of } 39 \\
(38 \%) \text { received prednisolone } \\
\text { and } 1 \text { of } 39(2.6 \%) \text { used } \\
\text { epinephrine autoinjector. }\end{array}$ & NCT01502878 & (258) \\
\hline $\begin{array}{l}\text { Peanut: peanut } \\
\text { flour (50\% } \\
\text { protein), for low } \\
\text { dose mixed with } \\
\text { oat flour; dose } \\
\text { of individual } \\
\text { major allergens } \\
\text { not determined }\end{array}$ & $\begin{array}{l}37 \text { subjects } \\
\text { (9-36 } \\
\text { months) } \\
\text { eligible for } \\
\text { study (5 } \\
\text { withdrew); } \\
154 \\
\text { standard- } \\
\text { care controls }\end{array}$ & $\begin{array}{l}\text { Randomized, } \\
\text { double-blind, } \\
\text { controlled }\end{array}$ & $\begin{array}{l}\text { Initial dose escalation. } \\
\text { Buildup-phase for } 42 \\
\text { weeks until maintenance } \\
\text { dose reached. Patients } \\
\text { received either low- or } \\
\text { high-dose early OIT } \\
\text { (maintenance dose } 300 \\
\text { mg or } 3000 \text { mg peanut } \\
\text { protein/day) and } \\
\text { underwent } 2 \text { final } \\
\text { DBPCFCs after a } \\
\text { maintenance phase of up } \\
\text { to } 36 \text { months. } \\
\text { Unresponsiveness } 4 \\
\text { weeks after stopping OIT } \\
\text { (4-SU) was defined by } \\
\text { toleration of } 5 \mathrm{~g} \text { peanut } \\
\text { protein (cumulative) during } \\
\text { DBPCFC. }\end{array}$ & $\begin{array}{l}\text { - } \text { subjects underwent first DBPCFC } \\
\text { to } 5 \mathrm{~g} \text { peanut, which two } \\
\text { failed. The others repeated } \\
\text { challenge after } 4 \text { weeks of } \\
\text { peanut avoidance, which was } \\
\text { completed by } 29 \text { patients. } \\
\text { Thus, } 29 \text { of } 37 \text { (78\%) } \\
\text { achieved } 4-S U \text { (primary } \\
\text { endpoint): } 17 / 20 \text { (85\%) in } \\
\text { low-dose, } 12 / 17(71 \%) \text { in } \\
\text { high-dose group. } 4 \text {-SU was } \\
\text { achieved over a median of } 29 \\
\text { months. } \\
30 \text { of } 37 \text { (81\%) subjects } \\
\text { achieved desensitization by } \\
\text { the end of the treatment } \\
\text { (intention-to-treat analysis): } \\
17 / 20 \text { (85\%) in low-dose and } \\
13 / 17 \text { (76\%) in high-dose } \\
\text { group }\end{array}$ & $\begin{array}{l}\text { Over the time of the study, } \\
\text { median peanut-specific lgE } \\
\text { level declined in OIT treated } \\
\text { subjects }\left(1.6 \mathrm{kU} \cup_{A} / L\right) \text {, } \\
\text { compared to the baseline } \\
\left(14.4 \mathrm{kU} \mathrm{U}_{\mathrm{A}} / \mathrm{L}\right) \text {, while there } \\
\text { was an increase in control } \\
\text { subjects }\left(57.4 \mathrm{kU} \mathrm{U}_{\mathrm{A}} / \mathrm{L}\right. \\
\text { compared to } 21.9 \mathrm{kU} / \mathrm{L} \text { at } \\
\text { baseline). success } \\
\text { Treatment with lower } \\
\text { correlated with } \\
\text { peanut-specific lgE and } \\
\text { peanut-specific lgE/total IgE } \\
\text { ratio at baseline. }\end{array}$ & $\begin{array}{l}\text { Of the initial } 37 \text { eligible } \\
\text { study participants, } 3 \\
\text { withdrew due to treatment- } \\
\text { related adverse reactions. } \\
\text { Overall, } 95 \% \text { of the } \\
\text { participants were affected } \\
\text { by adverse events which } \\
\text { occurred more frequently } \\
\text { during the build-up phase. } \\
\text { Most adverse events were } \\
\text { mild (85\%), } 15 \% \text { were } \\
\text { considered moderate and } \\
\text { no severe reaction was } \\
\text { reported. }\end{array}$ & NCT00932828 & (259) \\
\hline
\end{tabular}




\begin{tabular}{|c|c|c|c|c|c|c|c|c|}
\hline Allergen & $\begin{array}{l}\text { Number of } \\
\text { participant } \\
\text { (age) }\end{array}$ & Study design & Protocol summary & Clinical outcome & Serological outcome & Reported side effects & Clinical trial number & Ref. \\
\hline $\begin{array}{l}\text { Peanut: peanut } \\
\text { powder (protein } \\
\text { content not } \\
\text { specified); dose } \\
\text { of individual } \\
\text { major allergens } \\
\text { not determined }\end{array}$ & $\begin{array}{l}24 \text { (5-18 } \\
\text { years) } \\
\text { subjects with } \\
\text { history of } \\
\text { anaphylaxis in } \\
\text { OIT group, } \\
10 \text { historical } \\
\text { controls } \\
\text { (avoided } \\
\text { peanuts) }\end{array}$ & Open-label & $\begin{array}{l}\text { Subjects ingested peanut } \\
\text { powder } 2 \times / \text { day during } 5 \\
\text { days of hospitalization. Up } \\
\text { to } 1 \text { month after } \\
\text { discharge, dosing was } \\
\text { continued with amount } \\
\text { decided at time of } \\
\text { discharge. If dose was } \\
\text { tolerated for } 5 \\
\text { consecutive days after this } \\
\text { month, dose was } \\
\text { increased gradually until a } \\
\text { target dose of } 133 \text { mg } \\
\text { peanut protein/day was } \\
\text { reached. Patients visited } \\
\text { hospital every } 1-3 \text { months } \\
\text { (total duration } 12 \text { months). } \\
\text { One year after staring the } \\
\text { treatment, patients } \\
\text { stopped intake for } 2 \\
\text { weeks and then } \\
\text { underwent } 133 \text { mg and } \\
795 \text { mg OFC (on two } \\
\text { consecutive days). } \\
\text { Patients that passed the } \\
\text { challenges continued with } \\
\text { weekly ingestion of } 795 \\
\text { mg peanut protein. Those } \\
\text { without showing } \\
\text { symptoms } 3 \text { months after } \\
\text { OFC were considered } \\
\text { having achieved sustained } \\
\text { unresponsiveness. }\end{array}$ & $\begin{array}{l}\text { - After } 12 \text { months of } \\
\text { treatment, } 8 \text { (33\%) children in } \\
\text { the OIT group achieved } \\
\text { sustained unresponsiveness } \\
\text { compared to } 0 \% \text { in the } \\
\text { control group (primary } \\
\text { endpoint). } \\
22 \text { of } 24 \text { (92\%) participants } \\
\text { in the OIT group achieved } \\
\text { desensitization within } 12 \\
\text { months. } \\
\text { After } 1 \text { year, } 16 \text { (67\%) of the } \\
\text { OIT-treated children tolerated } \\
133 \text { mg and } 14 \text { (58\%) } \\
\text { tolerated } 795 \text { mg in OFC } \\
\text { compared to } 1 \text { of } 10 \text { (10\%) } \\
\text { and } 0 \text { of } 10(0 \%) \text { in the } \\
\text { historical control group. }\end{array}$ & $\begin{array}{l}\text { - The median peanut- and } \\
\text { Ara } \mathrm{h} 2 \text {-specific IgE levels } \\
\text { increased significantly } \\
\text { during the first month, and } \\
\text { then decreased at } 3,6 \text { and } \\
12 \text { months. } \\
\text { - } \text { Median peanut- and Ara h } \\
\text { 2-specific IgG and IgG4 } \\
\text { levels increased significantly } \\
\text { from baseline to } 1 \text { month in } \\
\text { the OIT group, while no } \\
\text { changes were observed in } \\
\text { the control group. } \\
\text { Baseline Ara } \mathrm{h} 2 \text {-specific IgE } \\
\text { levels were predictive for the } \\
\text { achievement of sustained } \\
\text { unresponsiveness. }\end{array}$ & $\begin{array}{l}\text { group } 50 \% \text { had mild and } \\
44.4 \% \text { had moderate side } \\
\text { effects. Severe adverse } \\
\text { events were reported in } \\
4.3 \% \text { in the OIT group and } \\
0.8 \% \text { in the placebo group. } \\
\text { In total, } 79 \text { of } 119 \\
\text { admission doses (66.4\%) } \\
\text { caused allergic reactions, } \\
\text { but none of them were } \\
\text { severe. During home } \\
\text { dosing, } 9.1 \% \text { of the } \\
\text { subjects experienced } \\
\text { adverse symptoms, which } \\
\text { were severe in } 0.01 \% \text { of } \\
\text { cases. One child required } \\
\text { treatment with epinephrine. }\end{array}$ & UMIN000011202 & (262) \\
\hline $\begin{array}{l}\text { Peanut: peanut } \\
\text { paste made } \\
\text { from roasted } \\
\text { peanut (protein } \\
\text { content } \\
\text { approximately } \\
20 \% \text { ): dose of }\end{array}$ & $\begin{array}{l}\text { Initially } 30 \\
\text { subjects (12- } \\
18 \text { years): } 21 \\
\text { in peanut OIT } \\
\text { group, } 9 \\
\text { placebo } \\
\text { controls: } 2\end{array}$ & $\begin{array}{l}\text { Randomized, } \\
\text { double-blind, } \\
\text { placebo- } \\
\text { controlled }\end{array}$ & $\begin{array}{l}\text { Initial DBPCFC, followed } \\
\text { by } 24 \text { weeks of build-up } \\
\text { phase during which } \\
\text { subjects ingested daily } \\
\text { doses between } 2-400 \mathrm{mg} \\
\text { peanut protein. Doses } \\
\text { were increased every } 2\end{array}$ & $\begin{array}{l}\text { - Primary endpoint was defined } \\
\text { by toleration of at least } 400 \\
\text { mg (cumulative) peanut protein } \\
\text { during DBPCFC, performed } 1 \text { - } \\
3 \text { days after the end of the } \\
\text { build-up phase. This was } \\
\text { achieved by } 17 \text { of } 21(81 \%)\end{array}$ & $\begin{array}{l}\text { Peanut-specific IgE levels } \\
\text { increased significantly in the } \\
\text { OIT group compared to the } \\
\text { placebo group at second } \\
\text { DBPCFC. } \\
\text { - No significant difference was } \\
\text { observed for Ara h 1-, 2- }\end{array}$ & $\begin{array}{l}\text { Two patients in the OIT } \\
\text { group withdrew during the } \\
\text { build-up phase. One due to } \\
\text { a severe reaction that } \\
\text { required epinephrine and } \\
\text { the other due to moderate } \\
\text { side effects. Overall, only } 3\end{array}$ & NCT02046083 & (263) \\
\hline
\end{tabular}




\begin{tabular}{|c|c|c|c|c|c|c|c|c|}
\hline Allergen & $\begin{array}{l}\text { Number of } \\
\text { participant } \\
\text { (age) }\end{array}$ & Study design & Protocol summary & Clinical outcome & Serological outcome & Reported side effects & Clinical trial number & Ref. \\
\hline $\begin{array}{l}\text { individual major } \\
\text { allergens not } \\
\text { determined }\end{array}$ & $\begin{array}{l}\text { patients } \\
\text { withdrew }\end{array}$ & & $\begin{array}{l}\text { weeks until subjects } \\
\text { reached daily doses of up } \\
\text { to } 400 \mathrm{mg} \text { peanut protein. } \\
\text { At the end of the build-up } \\
\text { phase, subjects } \\
\text { underwent DBPCFC. }\end{array}$ & $\begin{array}{l}\text { OIT treated subjects compared } \\
\text { to } 1 \text { of } 9 \text { (11\%) in the placebo } \\
\text { control group (intention-to-treat } \\
\text { analysis). } \\
17 \text { of } 19 \text { patients in the OIT } \\
\text { group that finished the build- } \\
\text { up protocol increased their } \\
\text { reactivity threshold } 4 \text {-fold } \\
\text { between first and second } \\
\text { DBPCFC compared to } 2 \text { of } 9 \\
\text { in the placebo group. }\end{array}$ & $\begin{array}{l}\text { and 3-specific IgE levels } \\
\text { between first and second } \\
\text { DBPCFC. } \\
\text { Peanut-specific IgG4 levels } \\
\text { increased significantly } \\
\text { during build-up phase. The } \\
\text { same applied for IgG4 levels } \\
\text { specific for major peanut } \\
\text { allergens. } \\
\text { Peanut and Ara h } 2 \text {-specific } \\
\text { lgG4/specific lgE ratios } \\
\text { increased in the OIT group } \\
\text { at the second DBPCFC, } \\
\text { and reached significance for } \\
\text { Ara } \mathrm{h} 2 \text {. } \\
\text { No difference in the peanut- } \\
\text { specific lgE/total IgE ratio } \\
\text { was observed in either } \\
\text { group during the build-up } \\
\text { phase. }\end{array}$ & $\begin{array}{l}\text { subjects experienced no } \\
\text { adverse event during the } \\
\text { build-up phase. While there } \\
\text { was no difference between } \\
\text { the number of patients with } \\
\text { adverse events between } \\
\text { both groups, the number of } \\
\text { events/patients was higher } \\
\text { in the OIT group. In 91/ } \\
1000 \text { doses medication was } \\
\text { required in the OIT group, } \\
\text { compared to } 36 / 1000 \text { in the } \\
\text { placebo group. Five } \\
\text { systemic reactions occurred } \\
\text { in } 4 \text { OIT-treated patients; } \\
\text { one was life-threatening. }\end{array}$ & & \\
\hline $\begin{array}{l}\text { Peanut: peanut } \\
\text { flour (50\% } \\
\text { protein) in } \\
\text { vehicle of } \\
\text { chocolate } \\
\text { pudding; dose } \\
\text { of individual } \\
\text { major allergens } \\
\text { not determined; } \\
\text { placebo group } \\
\text { only received } \\
\text { vehicle without } \\
\text { peanut flour }\end{array}$ & $\begin{array}{l}62 \text { subjects } \\
\text { (3-17 years): } \\
31 \text { in OIT } \\
\text { group, } 31 \\
\text { placebo } \\
\text { controls }\end{array}$ & $\begin{array}{l}\text { Randomized, } \\
\text { double-blind, } \\
\text { placebo- } \\
\text { controlled }\end{array}$ & $\begin{array}{l}\text { Initial dose escalation } \\
\text { phase during which } \\
\text { patients received whole } \\
\text { crushed roasted peanuts } \\
\text { starting with } 3 \text { mg peanut } \\
\text { protein in } 2 \text {-hour intervals } \\
\text { for a maximum of } 3 \text { days } \\
\text { until } 4500 \text { mg peanut } \\
\text { protein was reached or } \\
\text { objective symptoms were } \\
\text { observed. OIT was } \\
\text { started with doses of } 0.5- \\
30 \text { mg peanut protein, } \\
\text { depending on eliciting } \\
\text { dose during initial OFC. } \\
\text { Doses were taken on a } \\
\text { daily basis and increased } \\
\text { approximately every } 2 \\
\text { weeks (up to } 14 \text { months). } \\
\text { Patients with eliciting dose } \\
\text { of } 3-100 \text { mg during initial } \\
\text { OFC had goal } \\
\text { maintenance dose of } 125 \\
\text { mg, subjects with an } \\
\text { eliciting dose of } 300-4500 \\
\text { mg should reach a }\end{array}$ & $\begin{array}{l}\text { Primary endpoint was the } \\
\text { proportion of subjects } \\
\text { tolerating a single dose of at } \\
\text { least } 300 \mathrm{mg} \text { peanut protein } \\
\text { during final OFC, which was } \\
\text { achieved by } 23 / 31 \text { ( } 74.2 \%) \text { in } \\
\text { the active OIT group versus } \\
5 / 31(16.1 \%) \text { in the placebo } \\
\text { control group. } \\
13 \text { of } 31 \text { (41.9\%) subjects in } \\
\text { the active OIT group } \\
\text { compared to } 1 \text { of } 31 \text { (3.2\%) } \\
\text { in the placebo group } \\
\text { tolerated } 4.5 \text { g peanut } \\
\text { protein at final challenge. } \\
50 \% \text { in each group reached } \\
\text { the goal maintenance dose } \\
\text { (peanut protein or placebo). }\end{array}$ & $\begin{array}{l}\text { In the peanut-OIT group a } \\
\text { significant reduction in IL-4, } \\
\text { IL-5, IL-10 and IL-2 } \\
\text { production, a significant } \\
\text { increase in median peanut- } \\
\text { specific IgG4 levels and a } \\
\text { decrease in the peanut- } \\
\text { specific IgE/IgG4 ratio were } \\
\text { observed after treatment } \\
\text { when compared between } \\
\text { the randomized arms. }\end{array}$ & $\begin{array}{l}\text { Two patients in each group } \\
\text { withdrew due to } \\
\text { experiencing adverse } \\
\text { events, which were severe } \\
\text { in one of the subjects of } \\
\text { each group. All patients } \\
\text { experienced adverse events } \\
\text { at some point, however, } \\
\text { only } 1.2 \% \text { of placebo doses } \\
\text { and } 4.3 \% \text { of peanut OIT } \\
\text { doses were associated with } \\
\text { treatment-related adverse } \\
\text { reactions. } 40 \% \text { in the } \\
\text { placebo group and } 45 \% \text { in } \\
\text { the active OIT group } \\
\text { needed at least } 1 \text { dose } \\
\text { reduction because of } \\
\text { reported side effects. }\end{array}$ & DRKS00004553 & (264) \\
\hline
\end{tabular}




\begin{tabular}{|c|c|c|c|c|c|c|c|c|}
\hline Allergen & $\begin{array}{l}\text { Number of } \\
\text { participant } \\
\text { (age) }\end{array}$ & Study design & Protocol summary & Clinical outcome & Serological outcome & Reported side effects & Clinical trial number & Ref. \\
\hline & & & $\begin{array}{l}\text { maintenance dose of } 250 \\
\text { mg peanut protein. } \\
\text { Maintenance dose was } \\
\text { continued for } 2 \text { months } \\
\text { (+/- } 2 \text { weeks). }\end{array}$ & & & & & \\
\hline $\begin{array}{l}\text { Peanut: } \\
\text { suspension of } \\
\text { peanut flour in } \\
\text { Kool-Aid } \\
\text { containing } 2.5 \\
\mu \mathrm{g} \text { of peanut } \\
\text { protein; with } \\
\text { increasing } \\
\text { doses } \\
\text { alternative forms } \\
\text { of peanut were } \\
\text { provided with } \\
\text { equivalent } \\
\text { doses of peanut } \\
\text { protein; dose of } \\
\text { individual major } \\
\text { allergens not } \\
\text { determined }\end{array}$ & $\begin{array}{l}270 \text { subjects } \\
\text { (4-18 years) }\end{array}$ & $\begin{array}{l}\text { Retrospective } \\
\text { record }\end{array}$ & $\begin{array}{l}\text { Retrospective medical } \\
\text { record review of OIT } \\
\text { treated patients between } \\
2009 \text { and } 2017 \text {. Initial } \\
\text { dose escalation phase } \\
\text { with ingestion of tolerated } \\
\text { dose } 2 \times / \text { day for at least } 1 \\
\text { week before participants } \\
\text { returned for another dose } \\
\text { increase. Buildup phase } \\
\text { until target dose of } 3000 \\
\text { mg peanut protein } \\
\text { reached (individual } \\
\text { duration). } \\
\text { After } 6000 \text { mg peanut } \\
\text { protein challenge, } \\
\text { maintenance dose of } \\
2000 \text { mg was taken once } \\
\text { or twice daily for at least } 3 \\
\text { years. Sustained } \\
\text { unresponsiveness was } \\
\text { defined by passing } 6 \mathrm{~g} \\
\text { DBPCFC } 30 \text { days after } \\
\text { stopping OIT. }\end{array}$ & $\begin{array}{l}214 \text { of } 270(79 \%) \text { subjects } \\
\text { reached target maintenance } \\
\text { dose }(211 \text { reached target } \\
\text { dose of } 3000 \text { mg peanut } \\
\text { protein, } 3 \text { reduced target of } \\
2000 \mathrm{mg}) \text { and were } \\
\text { challenged with } 6000 \mathrm{mg} \\
\text { peanut protein, with all } \\
\text { except one passing the } \\
\text { challenge } \\
14 \text { of } 214 \quad(6.5 \%) \text { patients } \\
\text { achieved sustained } \\
\text { unresponsiveness. }\end{array}$ & $\begin{array}{l}\text { A decrease in peanut-specific } \\
\text { lgE levels was observed } \\
\text { during the maintenance } \\
\text { period. } \\
\text { In } 54 \text { tested patients, peanut- } \\
\text { specific lgG4 level after } \\
\text { reaching maintenance was } \\
>80 \mu g / m L, \text { however, } \\
\text { measurement was } \\
\text { discontinued afterwards. }\end{array}$ & $\begin{array}{l}\text { During dose escalation, } 63 \\
\text { of } 270(23 \%) \text { patients } \\
\text { required treatment with } \\
\text { epinephrine. In total, } 157 \\
\text { subjects (58\%) reported } \\
330 \text { minor adverse } \\
\text { reactions that did not } \\
\text { require treatment with } \\
\text { epinephrine. }\end{array}$ & $\begin{array}{l}\text { No clinical trial number } \\
\text { found; study was } \\
\text { approved by the North } \\
\text { Texas Institutional Review } \\
\text { Board }\end{array}$ & (265) \\
\hline $\begin{array}{l}\text { Walnut: } \\
\text { doses given as } \\
\text { mg of walnut } \\
\text { protein (not } \\
\text { further } \\
\text { specified); dose } \\
\text { of individual } \\
\text { major allergens } \\
\text { not determined }\end{array}$ & $\begin{array}{l}73 \text { subjects } \\
\text { ( } 4 \text { years or } \\
\text { older), } 55 \text { in } \\
\text { OIT group, } \\
18 \\
\text { observational } \\
\text { controls } \\
\text { (dietary } \\
\text { exclusion) }\end{array}$ & Prospective & $\begin{array}{l}\text { Initial dose escalation over } \\
4 \text { days (in in an } \\
\text { ambulatory care setting). } \\
\text { The highest tolerated } \\
\text { dose was consumed daily } \\
\text { for } 24 \text { days. Each month } \\
\text { patients returned for dose } \\
\text { escalations followed by } \\
\text { daily dose intake until } \\
\text { target dose of } 4000 \mathrm{mg} \\
\text { walnut protein was } \\
\text { reached (was considered } \\
\text { desensitization). } \\
\text { Maintenance of } 1200 \mathrm{mg} \\
\text { walnut protein/day for } 6 \\
\text { months in those patients } \\
\text { that were desensitized, }\end{array}$ & $\begin{array}{l}\text { Primary study endpoint was } \\
\text { defined as toleration of } 4000 \\
\text { mg walnut protein ( } 26 \mathrm{~g} \\
\text { walnut) by the end of the } \\
\text { study (desensitization). } \\
\text { Desensitization was achieved } \\
\text { in } 49 \text { of } 55(89 \%) \text { patients } \\
\text { (intention-to-treat analysis) in } \\
\text { the OIT group, compared to } \\
0 \text { of } 18(0 \%) \text { in the control } \\
\text { group. } \\
\text { Patients that were co-allergic } \\
\text { to pecan ( } n=46) \text { also } \\
\text { showed desensitization to } \\
\text { pecan. } \\
18 \text { of } 30(60 \%) \text { with co- } \\
\text { allergy to hazelnut or cashew }\end{array}$ & $\begin{array}{l}\text { In the walnut OIT group, } \\
\text { walnut-specific IgE levels, } \\
\text { CD63 expression in BAT } \\
\text { and IgE/lgG4 ratio } \\
\text { significantly decreased, } \\
\text { while walnut-specific lgG4 } \\
\text { levels increased during the } \\
\text { treatment period (similar } \\
\text { results for antibody levels to } \\
\text { all walnut-specific } \\
\text { components). This did not } \\
\text { apply for the control group. }\end{array}$ & $\begin{array}{l}\text { In total, } 47 \text { ( } 85 \%) \text { of } 55 \\
\text { patients in OIT group } \\
\text { experienced adverse } \\
\text { reactions during in-hospital } \\
\text { up-dosing and } 40(73 \%) \\
\text { during home-dosing. } \\
\text { However, reactions were } \\
\text { mostly mild and occurred in } \\
\text { response to } 109 \text { ( } 4 \% \text { ) of in- } \\
\text { clinic doses and } 244(2 \%) \\
\text { of home doses. Epinephrine } \\
\text { treatment was required by } \\
11 \text { patients during in- } \\
\text { hospital phase and } 8 \text { during } \\
\text { at home treatment. }\end{array}$ & $\begin{array}{l}\text { No clinical trial number } \\
\text { found; study was } \\
\text { approved by the } \\
\text { institutional review board }\end{array}$ & (266) \\
\hline
\end{tabular}




\begin{tabular}{|c|c|c|c|c|c|c|c|c|}
\hline Allergen & $\begin{array}{l}\text { Number of } \\
\text { participant } \\
\text { (age) }\end{array}$ & Study design & Protocol summary & Clinical outcome & Serological outcome & Reported side effects & Clinical trial number & Ref. \\
\hline & & & $\begin{array}{l}\text { followed by OFC to } 4000 \\
\text { mg walnut protein. } \\
\text { Crossover of control } \\
\text { group after observation } \\
\text { period (median period } 7.1 \\
\text { months). }\end{array}$ & $\begin{array}{l}\text { and } 14 \text { of } 15(93 \%) \text { with co- } \\
\text { allergy to hazelnut alone } \\
\text { were considered either fully } \\
\text { desensitized or treatment } \\
\text { responders. }\end{array}$ & & & & \\
\hline $\begin{array}{l}\text { Peanut: peanut } \\
\text { flour; protein } \\
\text { content was } \\
\text { calculated and } \\
\text { confirmed } \\
\text { through protein } \\
\text { assays (not } \\
\text { further } \\
\text { specified); oat } \\
\text { flour for placebo } \\
\text { group used }\end{array}$ & $\begin{array}{l}120 \text { subjects } \\
\text { ( } 7-55 \text { years): } \\
60 \text { in peanut- } \\
0 \text { group, } 35 \\
\text { in peanut- } \\
300 \text { group, } \\
25 \text { in placebo } \\
\text { group }\end{array}$ & $\begin{array}{l}\text { Randomized, } \\
\text { double-blind, } \\
\text { placebo- } \\
\text { controlled }\end{array}$ & $\begin{array}{l}\text { Buildup phase until } \\
\text { maintenance dose of } \\
4000 \text { mg peanut protein } \\
\text { reached (week 104), } \\
\text { followed by } \\
\text { discontinuation (peanut-0 } \\
\text { group), daily intake of } 300 \\
\text { mg peanut protein } \\
\text { (peanut-300 group) or } \\
\text { placebo for } 52 \text { weeks. } \\
\text { DBPCFC every } 3 \text { months } \\
\text { if a cumulative dose of } \\
4000 \text { mg peanut protein } \\
\text { was tolerated during } \\
\text { previous challenge. }\end{array}$ & $\begin{array}{l}\text { - Primary endpoint was defined } \\
\text { of proportion of subjects that } \\
\text { tolerated a cumulative dose } \\
\text { of } 4000 \text { mg peanut protein } \\
\text { during DBPCFC at week } 104 \\
\text { and week } 117 \text {. At week } 104 \text {, } \\
51 \text { of } 60 \text { ( } 85 \% \text { ) peanut-0 } \\
\text { subjects, } 29 \text { of } 35 \text { ( } 83 \%) \\
\text { peanut-300 subjects and } 1 \text { of } \\
25 \text { ( } 4 \% \text { ) in the placebo group } \\
\text { passed DBPCFC. At week } \\
117,21 \text { of } 60 \text { (35\%) peanut-0 } \\
\text { subjects, } 1 \text { of } 25 \text { (4\%) in the } \\
\text { placebo group and } 19 \text { of } 35 \\
\text { (54\%) peanut-300 subjects } \\
\text { passed } 4000 \text { mg challenge. } \\
\text { In the peanut-0 group, } 8 \text { of } \\
60 \text { (13\%) participants passed } \\
4000 \text { mg challenge after } \\
\text { week } 156 \text { compared to } 13 \text { of } \\
35 \text { (37\%) in the peanut-300 } \\
\text { group and } 1 \text { of } 25 \text { ( } 4 \% \text { ) in } \\
\text { the placebo group. }\end{array}$ & $\begin{array}{l}\text { - Lower peanut- and Ara h 2- } \\
\text { specific lgE levels were } \\
\text { associated with passing } \\
\text { challenge at week } 117 \text { in } \\
\text { the peanut-0 and the } \\
\text { peanut-300 arms. } \\
\text { - In the peanut-0 group, } \\
\text { higher peanut-specific IgG4/ } \\
\text { peanut-specific IgE ration } \\
\text { was associated with week } \\
117 \text { success, however, this } \\
\text { did not apply for the } \\
\text { peanut-300 group. } \\
\text { A higher Ara } \mathrm{h} \text { 2-specific } \\
\text { IgE/peanut-specific IgE ratio } \\
\text { was associated with higher } \\
\text { risk of treatment failure. }\end{array}$ & $\begin{array}{l}\text { Two patients withdrew due } \\
\text { to severe adverse events. } \\
\text { During the first year, } 95 \% \text { in } \\
\text { the peanut-0 group, } 91 \% \text { in } \\
\text { the peanut-300 group and } \\
64 \% \text { in the placebo group } \\
\text { reported adverse events. In } \\
\text { the third year, adverse } \\
\text { events were reported by } \\
2 \% \text { in the peanut-0 group, } \\
20 \% \text { in the peanut-300 } \\
\text { group and } 5 \% \text { in the } \\
\text { placebo group. }\end{array}$ & NCT02103270 & (267) \\
\hline $\begin{array}{l}\text { Hazelnut: } \\
\text { doses given as } \\
\text { mg of hazelnut } \\
\text { protein; } 259 \text { mg } \\
\text { hazelnut protein } \\
\text { equivalent to } 1 \\
\text { whole hazelnut; } \\
\text { dose of } \\
\text { individual major } \\
\text { allergens not } \\
\text { determined }\end{array}$ & $\begin{array}{l}100 \text { subjects } \\
\text { (3-9 years) }\end{array}$ & Retrospective & $\begin{array}{l}\text { DBPCFCs were } \\
\text { performed at time of } \\
\text { diagnosis and } 6 \text { months } \\
\text { after starting OIT. During } \\
\text { challenge doses were } \\
\text { increased every } 20 \\
\text { minutes up to a } \\
\text { cumulative dose of } 1635 \\
\text { mg hazelnut protein. } \\
\text { Buildup phase started } \\
\text { with one-tenth of eliciting } \\
\text { dose from initial DBPCFC. } \\
\text { Monthly dose increases } \\
\text { until tolerated cumulative } \\
\text { dose of } 1635 \text { mg hazelnut } \\
\text { protein (equivalent to } 8 \\
\text { whole hazelnuts) during }\end{array}$ & 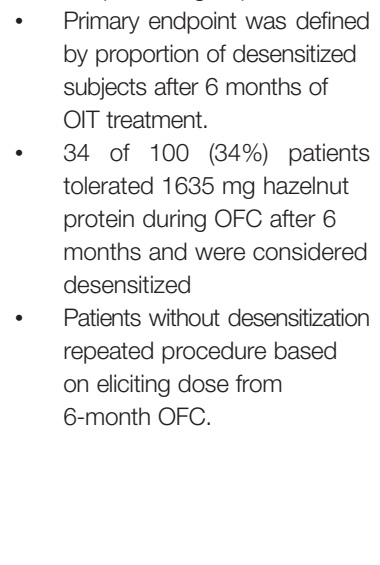 & $\begin{array}{l}\text { Desensitization to hazelnut } \\
\text { was associated with lower } \\
\text { hazelnut specific- and Cor a } \\
\text { 14-specific lgE levels. }\end{array}$ & $\begin{array}{l}76 \text { patients completed a } \\
\text { survey about OIT side } \\
\text { effects and } 30 \% \text { reported at } \\
\text { least one side effect (non- } \\
\text { severe). No serious adverse } \\
\text { reactions were reported. }\end{array}$ & NCT03048149 & (268) \\
\hline
\end{tabular}




\begin{tabular}{|c|c|c|c|c|c|c|c|c|}
\hline Allergen & $\begin{array}{l}\text { Number of } \\
\text { participant } \\
\text { (age) }\end{array}$ & Study design & Protocol summary & Clinical outcome & Serological outcome & Reported side effects & Clinical trial number & Ref. \\
\hline & & & $\begin{array}{l}\text { OFC (performed after } 6 \\
\text { months) was reached. } \\
\text { After passing OFC, } \\
\text { subjects continued with } \\
\text { maintenance dose of } 416 \\
\text { mg hazelnut protein } 3 \times / \\
\text { week. If OFC was failed, } \\
\text { schema was repeated } \\
\text { until desensitization was } \\
\text { achieved. }\end{array}$ & & & & & \\
\hline $\begin{array}{l}\text { Peanut: AR101 } \\
=\text { drug } \\
\text { consisting of } \\
\text { peanut flour; see } \\
\text { (Bird et al., } \\
\text { 2018) }\end{array}$ & $\begin{array}{l}175 \text { subjects } \\
\text { (4-17 years): } \\
132 \text { in AR101 } \\
\text { group, } 43 \text { in } \\
\text { placebo } \\
\text { group; } 106 \text { of } \\
\text { the AR101 } \\
\text { group and } 40 \\
\text { of the } \\
\text { placebo } \\
\text { group } \\
\text { completed } \\
\text { the study }\end{array}$ & $\begin{array}{l}\text { Randomized, } \\
\text { double-blind, } \\
\text { placebo- } \\
\text { controlled } \\
\text { (phase 3) }\end{array}$ & $\begin{array}{l}\text { Build-up phase with } \\
\text { biweekly dose increases } \\
\text { ( } 20-40 \text { weeks) until daily } \\
\text { dose of } 300 \text { mg peanut } \\
\text { protein (AR101) reached, } \\
\text { followed by maintenance } \\
\text { for } 3 \text { months. }\end{array}$ & $\begin{array}{l}\text { Primary endpoint was defined } \\
\text { by proportion of subjects that } \\
\text { could consume } 1000 \mathrm{mg} \\
\text { (cumulative dose } 2043 \mathrm{mg} \text { ) } \\
\text { peanut protein at final DBPCFC } \\
\text { (after } 9 \text { months) without dose- } \\
\text { limiting effects. } 77 \text { of originally } \\
132(58 \%) \text { subjects in the } \\
\text { AR101 group passed challenge } \\
\text { compared to } 1 \text { of } 43(2 \%) \text { in } \\
\text { the placebo group. }\end{array}$ & $\begin{array}{l}\text { - In the AR101 group peanut- } \\
\text { specific IgG4 levels } \\
\text { increased during the study. } \\
\text { No significant difference in } \\
\text { the change of peanut- } \\
\text { specific IgE levels was } \\
\text { observed between the } \\
\text { active treatment and the } \\
\text { placebo group. } \\
\text { A reduction in the IgE/IgG4 } \\
\text { ratio by the end of the trial } \\
\text { in comparison to the initial } \\
\text { screening in the AR101 } \\
\text { group. }\end{array}$ & $\begin{array}{l}\text { Adverse reactions were } \\
\text { reported by almost all } \\
\text { subjects, but were mostly } \\
\text { mild to moderate in both, } \\
\text { AR101 and placebo group. } \\
\text { One severe adverse event } \\
\text { was reported in the AR101 } \\
\text { group. Gastrointestinal } \\
\text { disorders were reported by } \\
91 \% \text { in the active treatment } \\
\text { group and } 77 \% \text { in the } \\
\text { placebo group. }\end{array}$ & NCT03201003 & (269) \\
\hline $\begin{array}{l}\text { Peanut: } \\
\text { PTAH, formerly } \\
\text { AR101 = drug } \\
\text { consisting of } \\
\text { peanut flour; see } \\
\text { (261) }\end{array}$ & $\begin{array}{l}358 \text { eligible } \\
\text { subjects (4- } \\
17 \text { years): } \\
256 \text { in } \\
\text { original active } \\
\text { treatment } \\
\text { group, } 102 \text { in } \\
\text { original } \\
\text { placebo } \\
\text { group }\end{array}$ & $\begin{array}{l}\text { Open-label, } \\
\text { follow-on } \\
\text { study to (261) }\end{array}$ & $\begin{array}{l}\text { Patients that reached } \\
\text { 300-mg dose at the exit } \\
\text { DBPCFC in previous } \\
\text { study and placebo group } \\
\text { entered the follow-on } \\
\text { study. Subjects were } \\
\text { assigned to } 5 \text { dosing } \\
\text { cohorts, receiving either } \\
\text { daily doses of } 300 \text { mg } \\
\text { (cohorts } 1 \text { and } 3 A \text { ) or } \\
\text { non-daily doses (cohorts } \\
2,3 B, 3 C) \text {. PTAH-naive } \\
\text { subjects (from initial } \\
\text { placebo group) underwent } \\
\text { buildup to daily dose of } \\
300 \text { mg, followed by } \\
\text { maintenance. At the end } \\
\text { of the study (approx. } 2 \\
\text { years), subjects } \\
\text { underwent DBPCFC up to } \\
2000 \text { mg peanut protein } \\
\text { (highest dose). }\end{array}$ & $\begin{array}{l}\text { - Cohort } 3 \mathrm{~A} \text { ( } 300 \mathrm{mg} \text { daily for } \\
\text { approx. } 56 \text { weeks) had } \\
\text { highest desensitization rates } \\
\text { - In PTAH-native group, } \\
\text { desensitization rates at } \\
\text { challenge doses of } 2000 \mathrm{mg} \\
\text { were } 45.8 \% \text { at maintenance } \\
\text { challenge (after } 24 \text { weeks of } \\
300 \mathrm{mg} \text { daily maintenance) } \\
\text { and } 51.4 \% \text { at exit challenge } \\
\text { (52 weeks after maintenance } \\
\text { challenge). }\end{array}$ & $\begin{array}{l}\text { - IgG4 levels increased during } \\
\text { the study period in daily- } \\
\text { dosing cohorts. } \\
\text { IgE levels decreased from } \\
\text { PALISADE entry to study } \\
\text { exit in PTAH-naiive and } \\
\text { PTAH-continuing subjects. }\end{array}$ & $\begin{array}{l}83 \% \text { of subjects } \\
\text { experienced mild to } \\
\text { moderate adverse events. } \\
6.1 \% \text { of subjects in non- } \\
\text { daily dosing group had to } \\
\text { revert to daily dosing due to } \\
\text { adverse events. Severe } \\
\text { adverse events occurred in } \\
2.1 \% \text { of daily-treated and } \\
2.7 \% \text { of non-daily treated } \\
\text { subjects. } 7 \text { participants in } \\
\text { PTAH-continuing group } \\
\text { withdrew due to adverse } \\
\text { events. In the PTAH-naiive } \\
\text { group, } 86 \% \text { experienced } \\
\text { treatment-related adverse } \\
\text { events. } 5 \text { subjects (from } \\
\text { cohorts } 1 \text { and } 3 C \text { ) } \\
\text { experienced treatment- } \\
\text { related anaphylaxis. }\end{array}$ & NCT02993107 & (270) \\
\hline
\end{tabular}




\begin{tabular}{ccccc}
\hline Allergen & $\begin{array}{c}\text { Number of } \\
\text { participant } \\
\text { (age) }\end{array}$ & Study design $\quad$ Protocol summary Clinical outcome & Serological outcome Reported side effects $\quad$ Clinical trial number & Ref.
\end{tabular}

(age)

\section{SLIT}

Hazelnut:

in glycerosaline 11 in active placebo- at least 3 minutes before

solution; dose of treatment controlled spitting out (sublingual-

individual major group, 11 in discharge technique).

allergens not placebo

determined; group

saline solution

used as placebo and placebo

sublingual

drops; active group, 7 in

18 subjects

(1-11 years):

group, 7
placebo group

extract $(1: 20 \mathrm{w} /$

v) dissolved in

$0.2 \%$

phenol and $50 \%$

- $55 \%$

glycerinated

saline to

maximum

peanut protein

concentration of

$5000 \mu \mathrm{gg} / \mathrm{ml}$; Ara

h 2 content was

approximately

$6 \%$ of protein

concentration;

placebo was

glycerinated

saline solution
5 of $11(45 \%)$ in the SLIT group and 1 of $11(9 \%)$ in

the placebo group tolerated

the highest level of $20 \mathrm{~g}$ raw

hazelnuts (15-20 hazelnuts)

in OFC.

hazelnut extract of 5

strengths (FO, F1, F2, F3,

FA). 4-day build-up phase during which doses were given in 15-minute

intervals, followed by daily

maintenance dose of 5

drops of maximum

concentration (vial

concentration (FA) 66.25

$\mathrm{mg} / \mathrm{ml}$ ) for 8-12 weeks.

Treatment efficacy was

assessed by DBPCFC at

the end of the study.

Randomized, Treatment started with

double-blind, $\quad 0.25 \mu \mathrm{g}$ peanut protein

placebo- (initial visit). Doses were

taken on a daily basis

taken on a daily

returned every 2 weeks

for dose escalation until

maintenance daily dose of

$2000 \mu \mathrm{g}$ peanut protein

was reached. Dose-

escalation for 6 months

was followed by 6 months

maintenance. Final

DBPCFC up to cumulative

dose of $2500 \mathrm{mg}$ peanut

protein performed after 12

months of treatment.

The primary endpoint was defined as the evaluation of

change in the reaction

threshold to peanut after

SLIT therapy compared to

placebo. 11 subjects of the

active SLIT group tolerated

cumulative dose of $1710 \mathrm{mg}$

peanut protein in DBPCFC

while 7 subjects in the

placebo group tolerated a

median cumulative dose of

$85 \mathrm{mg}$.
Hazelnut-, Cor a 1 - and Cor $\bullet 3$ of 1466 total SLIT

a 8-specific lgE levels were doses caused systemic

lower in both groups after reactions, which appeared

treatment (no statistical

significance).

during build-up phas

- In the treatment group, antihistamines.

increased mean lgG4 levels Local reactions (mainly

(7.34 allergen units (AU)/mL oral itching) were observed

to $9.84 \mathrm{AU} / \mathrm{mL}$ ) were

observed. However, no

statistical significance

regarding hazelnut-specific

lgG4 levels was found

between the groups.

- Increase in IL-10 levels ffrom

$1.62 \mathrm{pg} / \mathrm{mL}$ to $2.24 \mathrm{pg} / \mathrm{mL}$

was seen in the active SLIT

group after treatment.

after 12 months of treatment,

During the first 4 months, Adverse events were

associated with $11.5 \%$ of

increased significantly in the active SUIT doses and $8.6 \%$

active group (median level of placebo doses. No

$118.5 \mathrm{kU} /$ /L) compared to epinephrine was required

the baseline $\left(33.5 \mathrm{kU}_{\mathrm{A}} / \mathrm{L}\right) \quad$ any time during the study.

over the following 8

months decreased again

(median level of $31.4 \mathrm{kU}_{\mathrm{A}} / \mathrm{L}$ ).

After 1 years of treatment,

peanut-specific lgG4 levels

were significant higher in the

active SLIT group (1.12 mg/

L), compared to the
No clinical trial number

found; study was

approved by the ethics

committees of the

participating hospitals

baseline $(0.3 \mathrm{mg} / \mathrm{L})$,

however, this was not

observed in the placebo

group.

In the active SLIT group, IL

5 levels decreased

significantly during the

treatment in the active SLIT

group $(79 \mathrm{pg} / \mathrm{ml}$ ) compared

to the placebo group (368.9

$\mathrm{pg} / \mathrm{mll}$. 


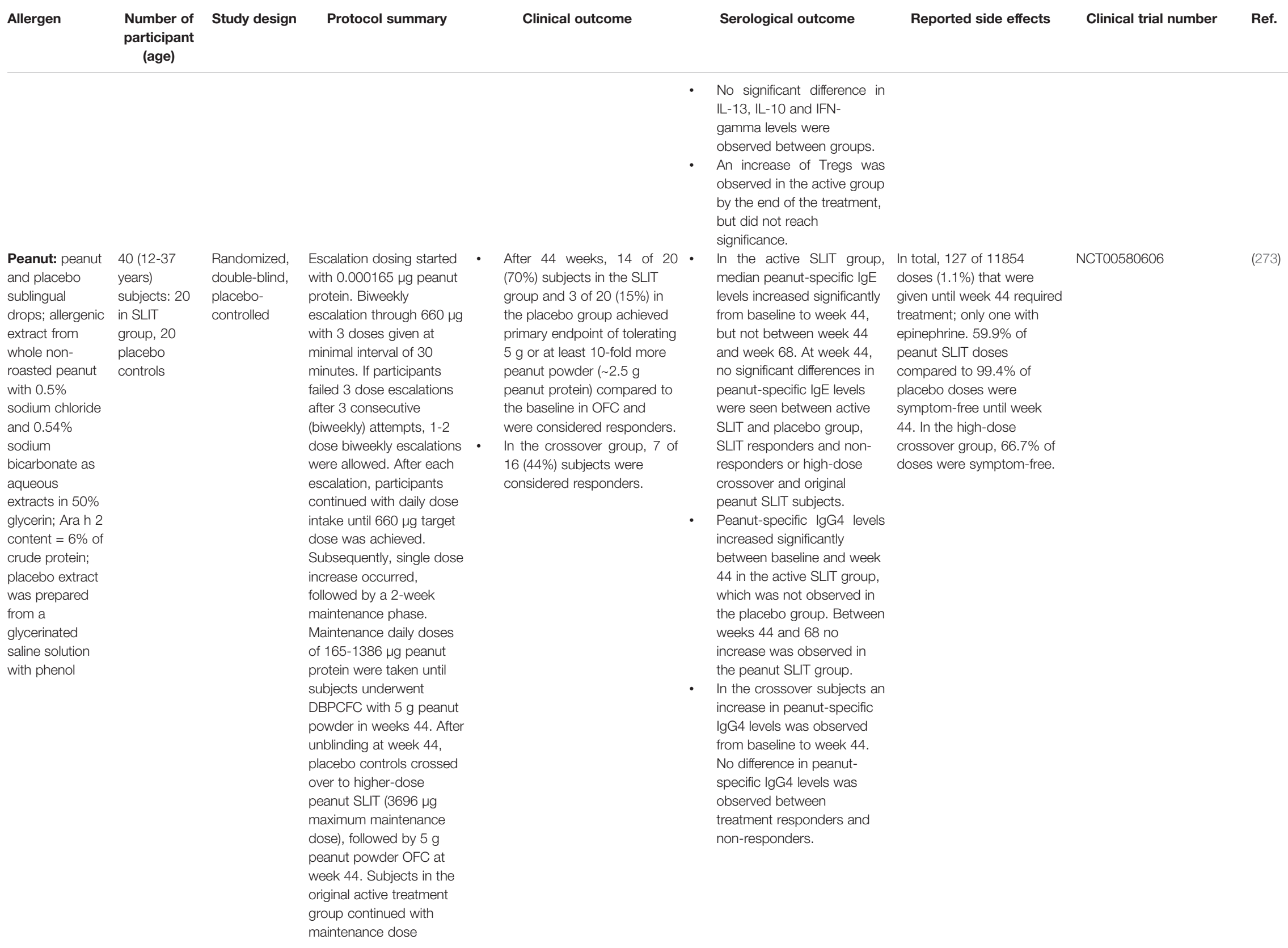




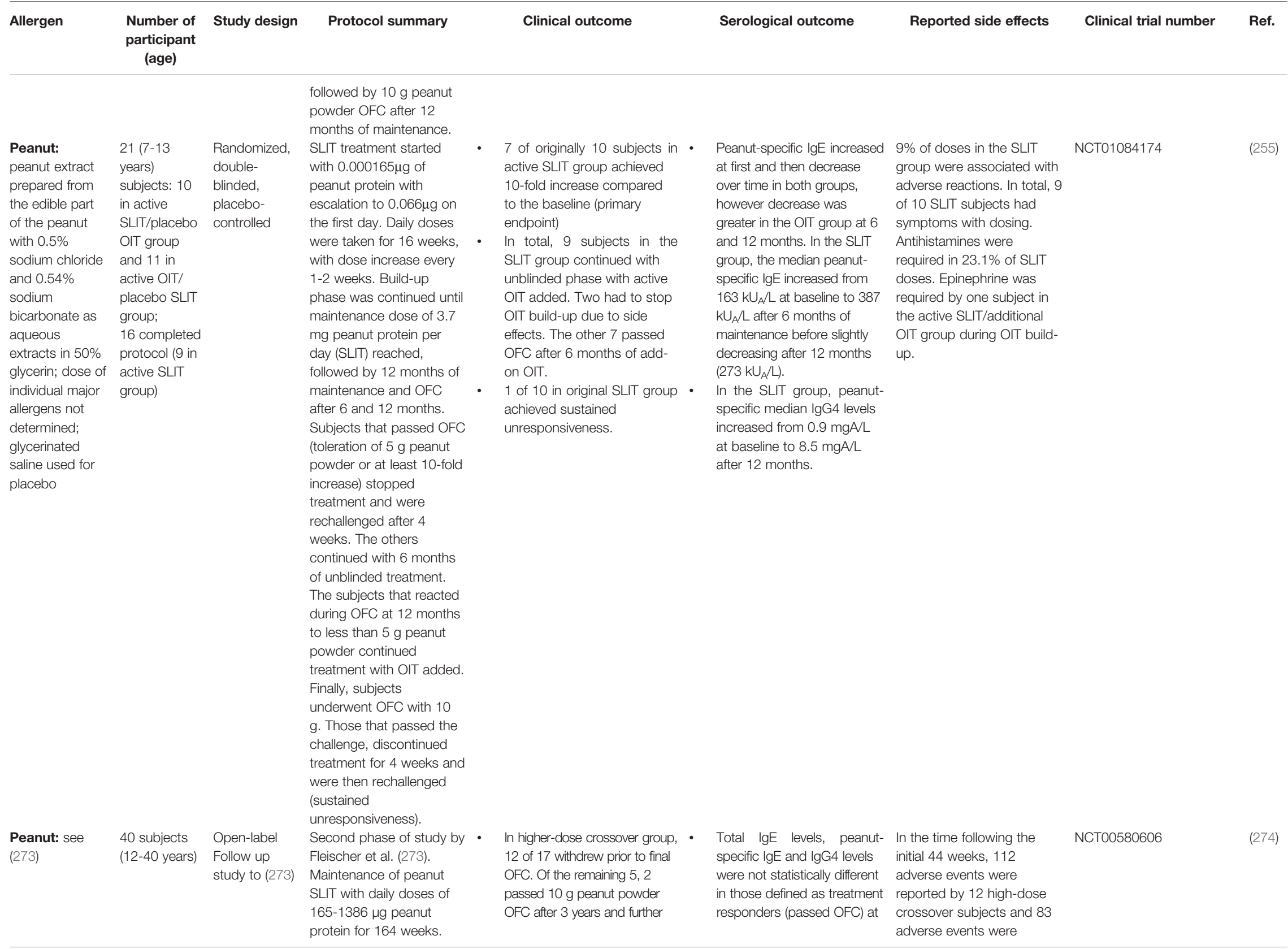




\begin{tabular}{|c|c|c|c|c|c|c|c|c|c|}
\hline Allergen & $\begin{array}{c}\text { Number of } \\
\text { participant } \\
\text { (age) }\end{array}$ & Study design & Protocol summary & Clinical outcome & & Serological outcome & Reported side effects & Clinical trial number & Ref. \\
\hline & & & $\begin{array}{l}\text { OFCs were performed at } \\
2 \text { and } 3 \text { years of SLIT } \\
\text { maintenance. Those } \\
\text { subjects that passed } 10 \mathrm{~g} \\
\text { peanut powder ( } 5 \mathrm{~g} \\
\text { peanut protein) OFC were } \\
\text { rechallenged after } 8 \\
\text { weeks of treatment } \\
\text { discontinuation to } \\
\text { evaluate sustained } \\
\text { unresponsiveness. } \\
\text { Sustained } \\
\text { unresponsiveness OFC } \\
\text { included challenge to } 10 \mathrm{~g} \\
\text { followed by open feeding } \\
\text { of } 2 \text { tablespoons peanut } \\
\text { butter } 1 \mathrm{~h} \text { later. }\end{array}$ & $\begin{array}{l}\text { achieved sustained } \\
\text { unresponsiveness. } \\
\text { In the initial active peanut } \\
\text { SLIT group, } 11 \text { of } 20 \\
\text { subjects withdrew prior to } \\
\text { final OFC. Of the remaining } \\
9,2 \text { passed OFC after } 3 \\
\text { years and further achieved } \\
\text { sustained unresponsiveness. }\end{array}$ & & $\begin{array}{l}\text { year } 2 \text { and those that were } \\
\text { non-responders. } \\
\text { Percentage of CD63+ } \\
\text { basophils was significantly } \\
\text { lower in the } 2 \text {-year } \\
\text { responders than in non- } \\
\text { responders. }\end{array}$ & $\begin{array}{l}\text { reported by } 13 \text { subjects in } \\
\text { the original peanut SLIT } \\
\text { group. In the peanut SLIT } \\
\text { group, } 1 \text { life-threatening } \\
\text { anaphylactic reaction } \\
\text { occurred during year } 3 \\
\text { OFC. However, only a mild } \\
\text { contact reaction was } \\
\text { considered definitely related } \\
\text { to the study product. }\end{array}$ & & \\
\hline $\begin{array}{l}\text { Peanut: see } \\
\text { study by Kim } \\
\text { et al. (272) }\end{array}$ & $\begin{array}{l}48 \text { subjects } \\
\text { (1-11 years) } \\
\text { initially } \\
\text { included: } 19 \\
\text { subjects from } \\
\text { the initial } \\
\text { study, } 11 \\
\text { subsequently } \\
\text { enrolled } \\
\text { subjects and } \\
18 \text { subjects } \\
\text { from an } \\
\text { additional } \\
\text { study cohort } \\
\text { that followed } \\
\text { identical } \\
\text { dosing } \\
\text { protocol; } 37 \\
\text { subjects } \\
\text { completed } \\
\text { SLIT therapy }\end{array}$ & $\begin{array}{l}\text { Open-label; } \\
\text { extension } \\
\text { study of (272) }\end{array}$ & $\begin{array}{l}\text { Initial study was described } \\
\text { above (272). An additional } \\
\text { cohort of patients that } \\
\text { followed identical protocol } \\
\text { were also included in the } \\
\text { extension study. During } \\
\text { the long-term extension } \\
\text { study, subjects received } \\
\text { SLIT with maintenance } \\
\text { daily dose of } 2 \text { mg peanut } \\
\text { protein (up to } 5 \text { years). } \\
\text { After the final day of SLIT, } \\
\text { sensitization was } \\
\text { assessed by DBPCFC } \\
\text { with } 5 \mathrm{~g} \text { peanut protein. }\end{array}$ & $\begin{array}{l}12 \text { of } 48 \text { (25\%) passed } \\
\text { challenge with } 5000 \text { mg peanut } \\
\text { protein without showing clinical } \\
\text { symptoms. } \\
\text { The } 12 \text { subjects discontinued } \\
\text { SLIT for } 2-4 \text { weeks, were } \\
\text { rechallenged and } 10 \text { subjects } \\
\text { demonstrated sustained } \\
\text { unresponsiveness. } \\
\text { Overall, } 37 \text { of } 48 \text { subjects } \\
\text { completed the SLIT } \\
\text { treatment (9 after } 3 \text { years, } 1 \\
\text { after } 4 \text { years, } 27 \text { after } 5 \\
\text { years). } \\
32 \text { of } 48 \text { (67\%) intention-to- } \\
\text { treat subjects tolerated at } \\
\text { least } 750 \text { mg peanut protein } \\
\text { during DBPCFC. }\end{array}$ & $\begin{array}{l}\cdot \\
\cdot \\
\cdot \\
\cdot \\
\cdot\end{array}$ & $\begin{array}{l}\text { The median peanut-specific } \\
\text { IgE level decreased } \\
\text { significant from baseline } \\
\left(83.9 \mathrm{kU}_{\mathrm{A}} / \mathrm{L}\right) \text { to study } \\
\text { completion }(20.0 \mathrm{kU} / \mathrm{L}) \text {. } \\
\text { Median peanut-specific } \\
\text { IgG4 level increased } \\
\text { significantly from baseline } \\
(0.3 \mathrm{mg} / \mathrm{L}) \text { to study } \\
\text { completion ( } 10.9 \mathrm{mg} / \mathrm{L}) \text {. } \\
\text { The peanut-specific lgG4/ } \\
\text { peanut-specific lgE ration } \\
\text { increased from } 1.45 \text { at } \\
\text { baseline to } 356.3 \text {. } \\
\text { Ratio of peanut-specific } \\
\text { basophil activation/non- } \\
\text { specific activation } \\
\text { decreased significantly. }\end{array}$ & $\begin{array}{l}\text { Of } 75,366 \text { total doses, } 3599 \\
(4.78 \%) \text { were associated } \\
\text { with side effects affecting } \\
45 / 48 \text { subjects. During end- } \\
\text { of-treatment DBPCFC, } 12 \\
\text { subjects required } \\
\text { epinephrine. During } \\
\text { sustained unresponsiveness } \\
\text { DBPCFC no epinephrine } \\
\text { treatment was required. }\end{array}$ & $\begin{array}{l}\text { No clinical trial number } \\
\text { found; protocol and } \\
\text { consent forms approved } \\
\text { by the local institutional } \\
\text { review board }\end{array}$ & (275) \\
\hline \multicolumn{10}{|l|}{ EPIT } \\
\hline $\begin{array}{l}\text { Peanut: Viaskin } \\
\text { peanut patch } \\
\text { containing liquid } \\
\text { formulation of } \\
\text { peanut protein } \\
\text { extract derived } \\
\text { from defatted }\end{array}$ & $\begin{array}{l}74 \text { subjects } \\
\text { (4-25 years) } \\
\text { started } \\
\text { dosing: } 24 \text { in } \\
\text { VP100 } \\
\text { group, } 25 \text { in } \\
\text { VP250 }\end{array}$ & $\begin{array}{l}\text { Randomized, } \\
\text { double-blind, } \\
\text { placebo- } \\
\text { controlled }\end{array}$ & $\begin{array}{l}\text { At study entry, subjects } \\
\text { underwent OFC with } \\
\text { cumulative dose of } 1044 \\
\text { mg peanut protein. } \\
\text { Participants either } \\
\text { received Viaskin Peanut } \\
100 \mu g \text { or Viaskin Peanut }\end{array}$ & $\begin{array}{l}\text { Primary endpoint was defined } \\
\text { by passing week-52 OFC with } \\
5044 \mathrm{mg} \text { peanut protein } \\
\text { (cumulative) or at least } 10 \text {-fold } \\
\text { increase compared to baseline, } \\
\text { which was achieved in } 11 \text { of } 24 \\
\text { (46\%) VP100-treated subjects, }\end{array}$ & $\cdot$ & $\begin{array}{l}\text { Subjects that received } \\
\text { active treatment had } \\
\text { increased peanut-specific } \\
\text { IgG4 levels and lgG } 4 / \text { /gE } \\
\text { ratios compared to the } \\
\text { placebo receiving subjects. }\end{array}$ & $\begin{array}{l}14.4 \% \text { of placebo doses } \\
\text { caused an adverse reaction } \\
\text { in comparison to } 79.8 \% \text { of } \\
\text { VP100 and VP250 doses. } \\
\text { Most reactions were mild } \\
\text { and occurred at patch site. } \\
\text { A patch-site reaction of }\end{array}$ & NCT01904604 & (276) \\
\hline
\end{tabular}




\begin{tabular}{|c|c|c|c|c|c|c|c|c|}
\hline Allergen & $\begin{array}{l}\text { Number of } \\
\text { participant } \\
\text { (age) }\end{array}$ & Study design & Protocol summary & Clinical outcome & Serological outcome & Reported side effects & Clinical trial number & Ref. \\
\hline $\begin{array}{l}\text { peanut flour; } \\
\text { Viaskin peanut } \\
100 \mu \mathrm{g} \text { (VP100) } \\
\text { or } 250 \mu \mathrm{g} \\
\text { (VP250) used for } \\
\text { treatment; dose } \\
\text { of individual } \\
\text { major allergens } \\
\text { not determined; } \\
\text { for placebo } \\
\text { same device } \\
\text { without peanut } \\
\text { protein }\end{array}$ & $\begin{array}{l}\text { group, } 25 \\
\text { placebo } \\
\text { controls }\end{array}$ & & $\begin{array}{l}250 \mu \mathrm{gg} \text {. Patch was placed } \\
\text { on upper arm (subjects } \\
\text { older than } 11 \text { years) or the } \\
\text { interscapular space } \\
\text { (subjects aged } 4-11 \\
\text { years). } 1-6 \text { application } \\
\text { sited were used at } 24-\mathrm{h} \\
\text { intervals. Doses were } \\
\text { increased by extending } \\
\text { duration the patch was } \\
\text { worn. In the first week, } \\
\text { patch was worn } 3 \mathrm{~h} / \text { day, } \\
\text { in week } 2,6 \mathrm{~h} / \text { day and } \\
\text { week } 3,12 \mathrm{~h} / \text { day. Patch } \\
\text { was applied } 24 \mathrm{~h} / \text { day } \\
\text { from day } 22 \text { on. At week } \\
52 \text {, subjects underwent } \\
\text { challenge with cumulative } \\
\text { dose of } 5044 \text { mg peanut } \\
\text { protein. }\end{array}$ & $\begin{array}{l}12 \text { of } 25 \text { (48\%) VP250-treated } \\
\text { subjects and } 3 \text { of } 25 \text { (12\%) in } \\
\text { the placebo group. } \\
\text { Higher treatment response } \\
\text { was observed in younger } \\
\text { children. }\end{array}$ & $\begin{array}{l}\text { - No difference between } \\
\text { treatments was seen for } \\
\text { total lgE levels and } \\
\text { percentage of peanut- } \\
\text { specific lgE over the time of } \\
\text { the study. } \\
\text { Median frequencies of T } \\
\text { cells producing IL-4 and IL- } \\
13 \text { were lower at the VP250 } \\
\text { dose compared to placebo, } \\
\text { but not at the VP100 dose. }\end{array}$ & $\begin{array}{l}\text { grade } 4 \text { was reported by } \\
\text { one patient with VP100 } \\
\text { dose at day } 34 \text {. Reactions } \\
\text { not limited to patch site } \\
\text { were associated with } 0.2 \% \\
\text { of placebo doses, } 0.2 \% \text { of } \\
\text { VP100 doses and } 0.1 \% \text { of } \\
\text { VP250 doses. No } \\
\text { epinephrine was required } \\
\text { with dosing. }\end{array}$ & & \\
\hline $\begin{array}{l}\text { Peanut: Viaskin } \\
\text { peanut patch } \\
\text { containing liquid } \\
\text { formulation of } \\
\text { peanut protein } \\
\text { extract derived } \\
\text { from defatted } \\
\text { peanut flour; } \\
\text { Viaskin patch } \\
\text { (VP) with } 50 \mu g \text {, } \\
100 \mu g \text { or } \\
250 \mu g \text { peanut } \\
\text { protein used for } \\
\text { treatment; dose } \\
\text { of individual } \\
\text { major allergens } \\
\text { not determined; } \\
\text { for placebo } \\
\text { same device } \\
\text { without peanut } \\
\text { protein }\end{array}$ & $\begin{array}{l}221 \text { (5-66 } \\
\text { years) } \\
\text { subjects: } 53 \\
\text { in VP50 } \\
\text { group, } 56 \text { in } \\
\text { VP100 } \\
\text { group, } 56 \text { in } \\
\text { VP250 } \\
\text { group, } 56 \text { in } \\
\text { placebo } \\
\text { group }\end{array}$ & $\begin{array}{l}\text { Phase } 2 \\
\text { double-blind, } \\
\text { placebo- } \\
\text { controlled } \\
\text { dose-ranging } \\
\text { study, } \\
\text { followed by } \\
\text { open-label } \\
\text { extension (for } \\
2 \text { years) }\end{array}$ & 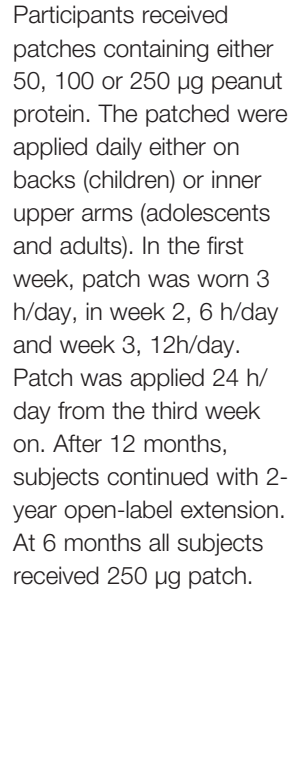 & $\begin{array}{l}\text { Primary endpoint was defined } \\
\text { as percentage of treatment } \\
\text { responders after } 12 \text { months of } \\
\text { treatment. Responders reached } \\
\text { at least } 10 \text {-times increase in the } \\
\text { eliciting dose and/or at least } \\
1000 \text { mg peanut protein in } \\
\text { OFC. } \\
\text { - This applied for } 28 \text { of } 56 \\
\text { (50\%) in the } 250-\mu g \text { group } \\
\text { compared to } 14 \text { of } 56 \text { ( } 25 \%) \\
\text { in the placebo group. } \\
\text { No statistically significant } \\
\text { difference in response rate } \\
\text { was observed between the } \\
100-\mu g \text { group and the } \\
\text { placebo control. } \\
\text { The highest difference in } \\
\text { response rate between the } \\
250-\mu g \text { group and the } \\
\text { placebo group was seen in } \\
\text { the age group between } 6 \\
\text { and } 11 \text { years. }\end{array}$ & $\begin{array}{l}\text { - In patch-treated subjects, } \\
\text { the median peanut-specific } \\
\text { IgE levels increased over the } \\
\text { first } 3-6 \text { months compared } \\
\text { to the placebo group, } \\
\text { followed by a decrease } \\
\text { reaching almost baseline } \\
\text { levels at } 12 \text { months. } \\
\text { - Peanut-specific lgG4 levels } \\
\text { increased over the } 12 \text { - } \\
\text { months treatment period in } \\
\text { all patch-treated subjects. } \\
\text { After } 12 \text { months, mean } \\
\text { peanut-specific lgG4 levels } \\
\text { were greater for VP250 } \\
\text { subjects than placebo } \\
\text { subjects. }\end{array}$ & $\begin{array}{l}\text { Treatment-emergent } \\
\text { adverse events occurred } \\
\text { primarily during the first } \\
\text { months of therapy and } \\
\text { twice as often in the } \\
\text { peanut-patch groups } \\
\text { compared to the placebo } \\
\text { group. Most adverse events } \\
\text { were local skin reactions. In } \\
\text { total, } 20 \text { serious adverse } \\
\text { events were reported in } 17 \\
\text { subjects, but none of them } \\
\text { were treatment-related and } \\
\text { most occurred during food } \\
\text { challenges. }\end{array}$ & NCT01675882 & (277) \\
\hline $\begin{array}{l}\text { Peanut: } 250 \mu \mathrm{g} \\
\text { peanut protein- } \\
\text { containing patch }\end{array}$ & $\begin{array}{l}356 \text { subjects } \\
\text { (4-11 years): } \\
238 \text { in }\end{array}$ & $\begin{array}{l}\text { Randomized, } \\
\text { double-blind, } \\
\text { placebo- }\end{array}$ & $\begin{array}{l}\text { Daily active treatment with } \\
250 \mu \mathrm{g} \text { peanut protein- } \\
\text { containing patch. }\end{array}$ & $\begin{array}{l}\text { - Primary endpoint was defined } \\
\text { by differences in the respond } \\
\text { rate between patch-treated }\end{array}$ & Not reported & $\begin{array}{l}\text { Incidence of treatment- } \\
\text { emergent adverse events } \\
\text { was } 95.4 \% \text { in the peanut- }\end{array}$ & NCT02636699 & (278) \\
\hline
\end{tabular}

$250 \mu \mathrm{g}$. Patch was placed

icipants received patches containing eithe was applied 24 . After 12 months, continued with 2 6 months all subjects ived $250 \mu \mathrm{g}$ patch.

containing patch 238 in $\begin{array}{ll}\text { placebo- } & \text { containing patch. }\end{array}$ 


\begin{tabular}{|c|c|c|c|c|c|c|c|c|c|c|}
\hline Allergen & $\begin{array}{l}\text { Number of } \\
\text { participant } \\
\text { (age) }\end{array}$ & Study design & Protocol summary & & Clinical outcome & & Serological outcome & Reported side effects & Clinical trial number & Ref. \\
\hline $\begin{array}{l}\text { (Viaskin); dose } \\
\text { of individual } \\
\text { major allergens } \\
\text { not determined; } \\
\text { for placebo } \\
\text { same device } \\
\text { without peanut } \\
\text { protein }\end{array}$ & $\begin{array}{l}\text { peanut-patch } \\
\text { group, } 118 \\
\text { placebo } \\
\text { controls }\end{array}$ & $\begin{array}{l}\text { controlled } \\
\text { (phase } 3 \text { trial) }\end{array}$ & $\begin{array}{l}\text { Treatment responders } \\
\text { were defined as those } \\
\text { passing OFC after } 12 \\
\text { months of treatment by } \\
\text { reaching at least } 300 \mathrm{mg} \\
\text { (for those with baseline } \\
\text { eliciting dose of } \leq 10 \mathrm{mg} \text { ) } \\
\text { or at least } 1000 \mathrm{mg} \\
\text { peanut protein (for those } \\
\text { that had baseline eliciting } \\
\text { dose of } 10-300 \mathrm{mg} \text { ). On } \\
\text { the first day patch was } \\
\text { worn } 3 \mathrm{~h} / \text { day, in week } 1 \text {, } \\
6 \mathrm{~h} / \text { day (gradually } \\
\text { increased) in week 2, 12h/ } \\
\text { day and thereafter patch } \\
\text { was applied } 24 \mathrm{~h} / \text { day. }\end{array}$ & & $\begin{array}{l}\text { and placebo-treated subjects } \\
\text { determined by OFC after } 12 \\
\text { months of treatment. } 84 \text { of } \\
238(35.3 \%) \text { of peanut-patch } \\
\text { treated subjects compared to } \\
16 \text { of } 118(13.6 \%) \text { in the } \\
\text { placebo group were } \\
\text { considered responders. }\end{array}$ & & & $\begin{array}{l}\text { patch group } \\
\text { and } 89 \% \text { in the placebo } \\
\text { group. Most adverse } \\
\text { reactions occurred at the } \\
\text { application site and primarily } \\
\text { within the first month. } 4 \\
\text { patients in the peanut-patch } \\
\text { group experienced adverse } \\
\text { events that led to treatment } \\
\text { discontinuation. } 4.2 \% \text { of } \\
\text { subjects in the peanut- } \\
\text { patch group and } 5.1 \% \text { in } \\
\text { the placebo group reported } \\
\text { serious adverse events at } \\
\text { any time during the study } \\
\text { (excluding OFC). }\end{array}$ & & \\
\hline \multicolumn{11}{|l|}{ Molecular AIT } \\
\hline $\begin{array}{l}\text { Peanut: rectally } \\
\text { administered } \\
\text { vaccine (EMP- } \\
\text { 123) consisting } \\
\text { of recombinant } \\
\text { modified Ara } \\
\text { h 1, Ara h 2, } \\
\text { and Ara h } \\
\text { 3, encapsulated } \\
\text { within heat/ } \\
\text { phenol } \\
\text { inactivated E. } \\
\text { coli. }\end{array}$ & $\begin{array}{l}10 \text { peanut- } \\
\text { allergic } \\
\text { subjects (18- } \\
50 \text { years) and } \\
5 \text { healthy } \\
\text { subjects }\end{array}$ & Phase 1 trial & $\begin{array}{l}\text { Rectally administration of } \\
\text { EMP-123. } \\
\text { Five healthy control } \\
\text { subjects received } 4 \\
\text { weekly escalating doses } \\
\text { up to a maximum of } 3063 \\
\mu \mathrm{g} \text { modified peanut } \\
\text { protein. } \\
\text { Peanut-allergic patients } \\
\text { received weekly dose } \\
\text { escalations for } 10 \text { weeks } \\
\text { (10-3063 } \mu \mathrm{g} \text { ), followed by } \\
3 \text { biweekly doses of } 3063 \\
\mu \mathrm{g} \text { (maximum dose). }\end{array}$ & • & $\begin{array}{l}\text { Primary endpoint was defined } \\
\text { as assessment of safety of } \\
\text { EMP-123 in peanut-allergic } \\
\text { subjects and healthy controls. } \\
4 \text { of } 10 \text { peanut-allergic patients } \\
\text { completed dosing without } \\
\text { experiencing symptoms. } 1 \\
\text { subjects experienced rectal } \\
\text { pruritus, but completed } \\
\text { treatment and was considered } \\
\text { non-reactive. } \\
2 \text { subjects had mild adverse } \\
\text { reactions, } 3 \text { experienced } \\
\text { more severe side effects, } \\
\text { including } 2 \text { anaphylactic } \\
\text { reactions. } \\
\text { In the healthy subject group, } \\
2 \text { experienced diarrhea or } \\
\text { loose stools after dosing. }\end{array}$ & $\begin{array}{r}\cdot \\
. \\
\cdot \\
\cdot\end{array}$ & $\begin{array}{l}\text { In healthy subjects no } \\
\text { immunological changes } \\
\text { were observed. } \\
\text { No significant changes in } \\
\text { peanut-specific lgE levels } \\
\text { from baseline to week } 20 \\
\text { were observed for reactive } \\
\text { and non-reactive subjects, } \\
\text { however, baseline peanut- } \\
\text { and Ara h } 2 \text {-specific lgE } \\
\text { levels were higher in the } 5 \\
\text { reactive subjects. } \\
\text { Peanut-specific IgG4 levels } \\
\text { did not change significantly } \\
\text { from baseline to week } 20 \text {. }\end{array}$ & See clinical outcome & $\begin{array}{l}\text { No clinical trial number } \\
\text { found; study approved } \\
\text { by the NIAID Data Safety } \\
\text { Monitoring Board, the } \\
\text { investigational review } \\
\text { boards of Mount Sinai } \\
\text { and Johns Hopkins, and } \\
\text { the NIH Recombinant } \\
\text { DNA Advisory } \\
\text { Committee }\end{array}$ & (279) \\
\hline
\end{tabular}

Design of studies, numbers of participants, outcomes, side effects and references are listed. 
benefits were relatively modest when put into context with side effects. Accordingly there are different opinions about OIT. One metanalysis (286) concluded: "In patients with peanut allergy, high-certainty evidence shows that available peanut oral immunotherapy regimens considerably increase allergic and anaphylactic reactions over avoidance or placebo, despite effectively inducing desensitization. Safer peanut allergy treatment approaches and rigorous randomized controlled trials that evaluate patient-important outcomes are needed." whereas another opinion was more optimistic (287). Nevertheless, Aimmune's peanut OIT has been approved by FDA in the USA and is now marketed as "Palforzia" (https:// www.fda.gov/vaccines-blood-biologics/allergenics/palforzia).

\subsection{Sublingual Immunotherapy}

Another possible form of immunotherapy for nut allergy is sublingual immunotherapy, which is given in the form of allergen-containing tablets or drops that must be kept under the tongue. One intention for the development of SLIT was the reduction of side effects and its simplified application for selfadministration by the patients. However, clinical effects of SLIT are less pronounced than for SCIT for respiratory allergens (235) and there are only few studies, most of them performed in few patients for nut allergy (Table 3) $(255,271-275)$. Although few studies showed desensitization in some of the participants by the end of the therapy, the results regarding sustained unresponsiveness and long-term compliance are not encouraging $(255,274)$.

\subsection{Epicutaneous Immunotherapy}

Epicutaneous immunotherapy (EPIT) is a more recent approach which has been developed originally for AIT of respiratory allergy (288) but has now been evaluated also for AIT of peanut allergy (235, 289). EPIT is based on the direct application of an allergen-containing patch on the patient's skin, similar as it is performed in APT. In theory, EPIT promises a reduced risk of systemic reactions and an uncomplicated application, also for children, due to its non-invasive nature. Table 3 provides an overview of current EPIT studies for nut allergy (276-278), which, however, is currently limited exclusively to peanut. Moderate success for the treatment of peanut allergy was reported, with one study showing some efficacy in children between 6 and 11 years (277). A review of available data states that "EPIT might induce desensitization in peanut allergy and an increased risk of local adverse events (AEs). These findings should be interpreted with caution owing to the limited study and heterogeneity. More data in the older (children $\geq 12$ years and adults) and other allergic diseases are needed" (289). The analysis of systemic peanut allergen-specific IgG responses has shown that epicutaneous allergen administration induces only a very modest production of allergen-specific IgG and mainly specific T cell activation (16).

\subsection{Molecular Immunotherapy via the Subcutaneous Route}

As already mentioned above, SCIT has not been developed for AIT of allergy to class I food allergens, most likely because of the risk of inducing anaphylactic side effects when natural allergen extracts are used $(244,245)$.
Regarding molecular AIT we found only one published study in which peanut allergic subjects had been treated by a molecular form of AIT using recombinant modified Ara h 1, 2 and 3 encapsulated in inactivated Escherichia coli (279) (Table 3) but half of the subjects (5/10) in this trial experienced adverse reactions, and two of them had anaphylactic reactions.

For AIT of respiratory allergy, several molecular AIT approaches have been evaluated already in clinical trials (Figure 4), yielding encouraging results in terms of inducing protective IgG responses, alterations of cellular immune responses and evidence for clinical efficacy (235). These approaches include SCIT with recombinant or purified major allergen molecules (290), SCIT based on recombinant hypoallergenic allergen derivatives with (291) and without allergen-specific $\mathrm{T}$ cell epitopes $(237,292)$. For the latter approaches the induction of allergen-specific blocking IgG antibodies has been demonstrated and evidence for clinical efficacy has been obtained. SCIT with allergen-derived T cell epitope-containing peptides has not been successful and an induction of allergen-specific IgG has only been demonstrated when relatively long peptides had been used [reviewed in (235)].

Regarding the development of molecular AIT approaches for treatment of allergy to class I food allergens, important and promising results have been collected for the major fish allergen parvalbumin which such as the major nut allergens represents a digestion-resistant and highly allergenic molecule (293). Within the European Union-funded research program FAST, a hypoallergenic recombinant mutant protein of the major carp allergen Cyp c 1 (294) has been produced, characterized and shown to be hypoallergenic in vivo (295-297). Furthermore, safety and ability to induce protective specific IgG responses has been demonstrated in first clinical trials for this molecular vaccine (https://clinicaltrials. gov/: NCT02017626; NCT02382718). Thus it has been proven that it is possible to develop recombinant hypoallergens for SCIT of class I allergens. First recombinant hypoallergenic derivatives of peanut allergens have been characterized in preclinical studies. In fact, several studies reported the production of modified allergen variants of the peanut allergens Ara h 1, Ara h 2 and Ara h 3 and demonstrated reduced $\operatorname{IgE}$ reactivity by immunoblotting using patient's sera (298-300). More recently, the generation of hypoallergenic variants of Ara h 2 and Ara h 6 with decreased allergenic activity but preserved T-cell proliferation capacity has been described (301). Similarly, Tscheppe et al. reported the production of a novel Ara $\mathrm{h} 2$ hypoallergen lacking linear and conformational IgE epitopes (47). IgE reactivity to the unfolded mutant was tested using sera from Ara h 2-sensitized patients and showed reduced IgE-binding capacity compared to natural Ara h 2. The Ara h 2 mutant exhibited low basophil activation ability but still induced T-cell proliferation.

It is known that for allergy to class II food allergens beneficial effects can be obtained by SCIT with the genuinely sensitizing cross-reactive respiratory allergens $(40,302)$ but the effects on food allergy seem to be lower due to limited cross-reactivity of the induced IgG antibodies (303).

Likewise, molecular AIT with recombinant hypoallergenic birch pollen allergen derivatives was found to induce also cross-protective 


\section{SCIT with recombinant T cell epitope-containing hypoallergens}

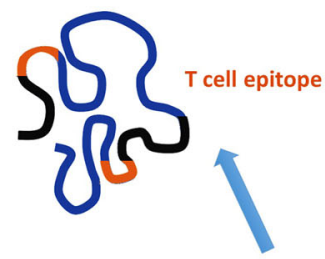

\section{Preventive administration of tolerogenic T cell epitope-containing allergen peptides}

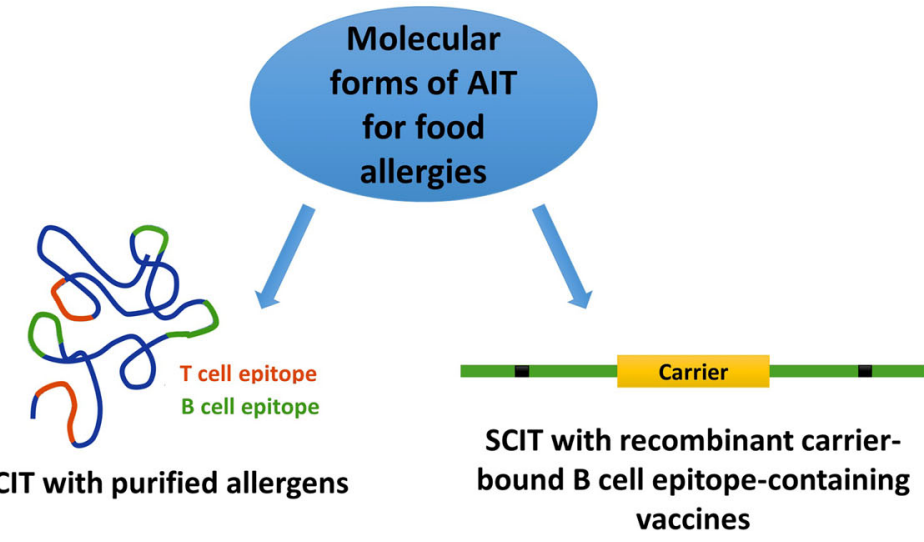

SCIT with purified allergens
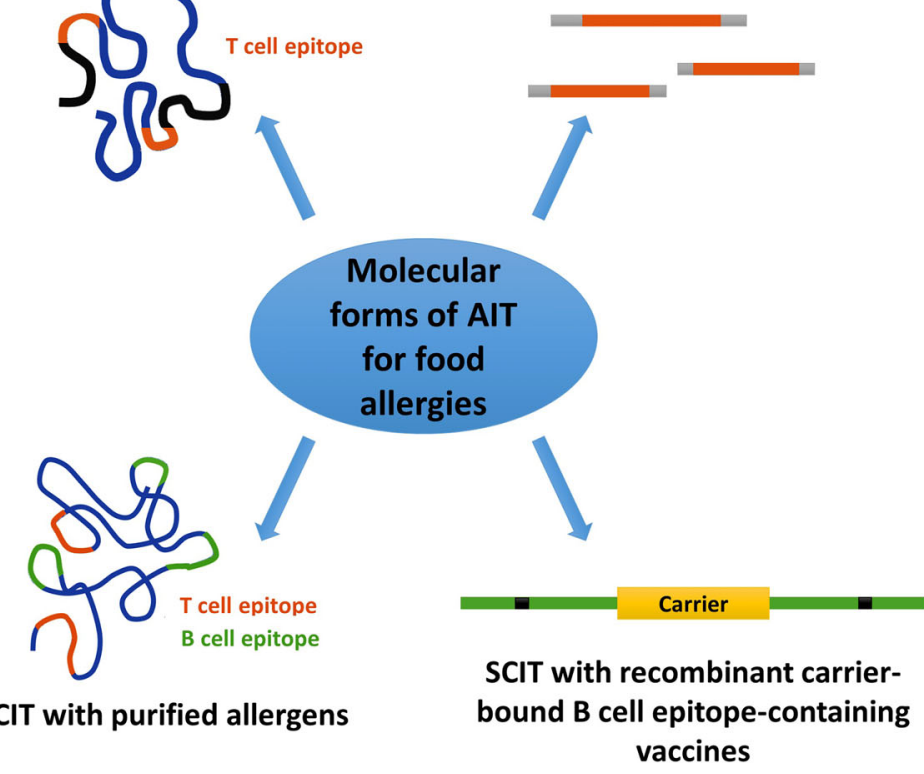

FIGURE 4 | Molecular forms of AIT which can be used for SCIT approaches in nut allergy.

IgG antibodies to cross-reactive food allergens $(41,291)$ but similar as for natural allergen extracts, there seems to be limited crossreactivity of therapy-induced IgG with the cross-reactive food allergens. This has been observed in the clinical trials but also in preclinical studies investigating the cross-protective potential of antibodies induced with molecular vaccines made for the treatment of respiratory allergy $(304,305)$. Accordingly, it has been suggested to develop recombinant hypoallergens which incorporate also epitopes of the cross-reactive food allergen molecules (306).

\subsection{Future Molecular Forms of AlTs for Nut Allergy: How to Crack the Nut}

Originally, recombinant hypoallergenic allergen derivatives have been made to incorporate allergen-specific $\mathrm{T}$ cell epitopes but it has been realized that also non-IgE reactive $\mathrm{T}$ cell epitopes can cause side effects by activating allergen-specific $\mathrm{T}$ cells leading to late phase side effects $(192,307,308)$. The more recently developed technology of replacing allergen-specific $\mathrm{T}$ cell epitopes by unrelated carrier proteins (309) seems to reduce $\mathrm{T}$ cell-mediated side effects and has been shown to yield promising clinical data with approximately $25 \%$ improvement of symptoms over placebo when tested for SCIT of grass pollen allergy (237). One may therefore consider the development of carrier-based B cell epitope-containing vaccines by combining peptides derived from the IgE binding sites of the respiratory allergens and the corresponding cross-reactive class II food allergens to obtain combination vaccines for treatment of pollen allergy and the associated oral allergy syndrome (Figure 4, lower, right).

The technology of producing fusion proteins consisting of hypoallergenic peptides derived from IgE binding sites of allergens and allergen-unrelated carrier proteins may be applicable also for class I food allergens. However, it needs to be born in mind that it may be more difficult to identify hypoallergenic peptides in class I food allergens because they may harbor not only conformational IgE epitopes which can be easily disrupted but also sequential $\mathrm{IgE}$ epitopes of which some may be cryptic (i.e., hidden in the intact allergen structure and exposed only after digestion). It may therefore be difficult to identify non-allergenic peptides derived from the IgE binding sites of class I food allergens which are needed for the construction of the carrier-bound B cell epitope-containing vaccines. SCIT with recombinant purified class I food allergens is in principle possible but vaccines based on purified wild-type allergens may cause severe side effects. SCIT with recombinant $\mathrm{T}$ cell epitope-containing hypoallergens derived from class I food allergens seems possible and effective if the vaccines induce allergen-specific protective IgG antibodies but late phase, $\mathrm{T}$ cell-mediated side effects may occur. Treatment with $\mathrm{T}$ cell epitopecontaining peptides from class I food allergens will likely not be successful because short peptides fail to induce protective $\operatorname{IgG}$ antibodies but tolerogenic peptides may be considered for preventive approaches (Figure 4).

If one performs an analysis of strengths and weaknesses of current allergen extract-based AIT approaches for nut allergy and future molecular AIT vaccines several aspects need to be considered 
(Figure 5). Without doubt, advances have been made regarding the development of allergen extract-based AIT for nut allergy and experience has been collected in several clinical trials (Figure 5 and Table 3). However, the major limitation for allergen extractbased forms of treatment resides in the fact that allergen extracts represent natural products which have major limitations regarding quality, allergen composition, purity and allergenic activity which only can be overcome by introducing molecular approaches for treatment (Figure 5) (193). It seems to be due to side effects that SCIT approaches with natural allergen extracts for treating allergy to class I food allergens were not pursued. Instead, mainly OIT approaches have been investigated in larger trials whereas SLIT and EPIT are still in an experimental stage. Side effects are still a concern in OIT with allergen extracts and may be overcome with molecular AIT technologies using hypoallergenic allergen derivatives (Figure 5).

Studies performed with molecular AIT approaches indicate high potential but more efforts are needed to advance this treatment into clinical trials and into clinical use. Accordingly, hypoallergenic derivatives need to be developed for the most important allergens, and thus a thorough preclinical and clinical characterization needs to be performed which will require large efforts and investment into the development (Figure 5). Most of the experiences have been collected for AIT of respiratory allergy but experience from preclinical and clinical trials in food allergy suggest a common mode of action indicating that SCIT with recombinant nut hypoallergens should be safe, induce protective
IgG responses and exhibit clinical efficacy but clinical studies are lacking. Clear advantages of molecular AIT forms are the defined mode of production which satisfies Good Manufacturing Practice requirements needed for clinical studies. A major possible advantage is that molecular design will allow to develop safe and effective forms of AIT for allergy to class I food allergens. Furthermore, molecular AIT can be ideally combined with the already established forms of molecular diagnosis allowing the adequate selection of patients for treatment and also the monitoring of the treatment using molecular biomarkers (209, $236,310)$.

Figure 5 provides a summary of the SWOT analysis of existing allergen extract-based forms of AIT for nut allergy and future forms of molecular AIT but much more needs to be done regarding the preclinical and clinical development of molecular AIT forms for food allergy.

\section{SUMMARY AND CONCLUSION}

Nut allergies might lead to severe allergic reactions or even death, and yet the only current treatment option is avoidance of the allergen source. For AIT as well as in nut allergy diagnosis, extract-based methods are still used. Molecular diagnosis is an alternative to traditional allergen-extract based diagnosis and molecular AIT is a promising future perspective. Molecular AIT approaches require knowledge of molecular sensitization profiles

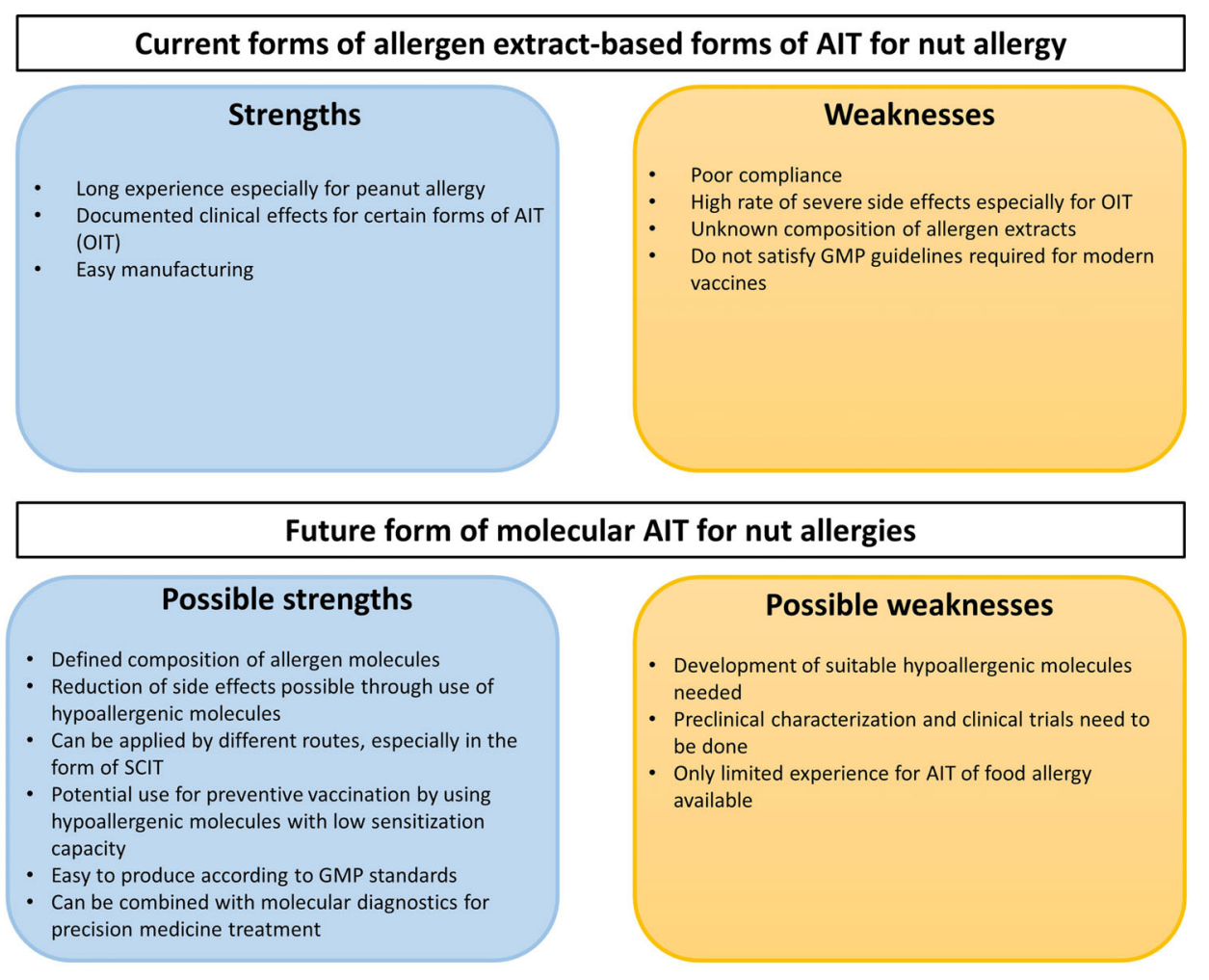

FIGURE 5 | SWOT analysis of existing allergen extract-based forms of AIT for nut allergy and future molecular AIT approaches. 
in the population intended to treat. It is evident that currently available studies regarding prevalence of sensitization and allergy to nuts are highly heterogeneous regarding design and only few contain information about molecular sensitization profiles. Therefore, there is a need for molecular studies to obtain comparable data regarding the prevalence of allergy to certain nuts. Molecular IgE-based diagnosis for nut allergy diagnosis may reduce the risk of side effects by reducing the need for provocation tests and promises more comprehensive results. At the moment mainly oral forms of allergen-specific immunotherapy are studied which suffer from poor patients compliance and severe side effects. Molecular AIT is not yet well investigated for treatment of nut allergy although it promises a reduction of side effects through the use of recombinant hypoallergens.

\section{AUTHOR CONTRIBUTIONS}

$\mathrm{RV}, \mathrm{VF}$, and BES wrote the manuscript. RV, VF, and BES designed the figures and tables. VF, MvH, BL, MF-T, IS, OE, AA and MK

\section{REFERENCES}

1. Blanco Mejia S, Kendall CW, Viguiliouk E, Augustin LS, Ha V, Cozma AI, et al. Effect of Tree Nuts on Metabolic Syndrome Criteria: A Systematic Review and Meta-Analysis of Randomised Controlled Trials. BMJ Open (2014) 4:e004660. doi: 10.1136/bmjopen-2013-004660

2. Del Gobbo LC, Falk MC, Feldman R, Lewis K, Mozaffarian D. Effects of Tree Nuts on Blood Lipids, Apolipoproteins, and Blood Pressure: Systematic Review, Meta-Analysis, and Dose-Response of 61 Controlled Intervention Trials. Am J Clin Nutr (2015) 102:1347-56. doi: 10.3945/ajcn.115.110965

3. Bock SA, Muñoz-Furlong A, Sampson HA. Fatalities Due to Anaphylactic Reactions to Foods. J Allergy Clin Immunol (2001) 107:191-3. doi: 10.1067/ mai.2001.112031

4. Bock SA, Muñoz-Furlong A, Sampson HA. Further Fatalities Caused by Anaphylactic Reactions to Food, 2001-2006. J Allergy Clin Immunol (2007) 119:1016-8. doi: 10.1016/j.jaci.2006.12.622

5. Gonzalez-Estrada A, Silvers SK, Klein A, Zell K, Wang XF, Lang DM. Epidemiology of Anaphylaxis at a Tertiary Care Center: A Report of 730 Cases. Ann Allergy Asthma Immunol (2017) 118:80-5. doi: 10.1016/ j.anai.2016.10.025

6. Kahveci M, Akarsu A, Koken G, Sahiner UM, Soyer O, Sekerel BE. FoodInduced Anaphylaxis in Infants, as Compared to Toddlers and Preschool Children in Turkey. Pediatr Allergy Immunol (2020) 31:954-61. doi: $10.1111 /$ pai. 13320

7. Sicherer SH, Burks AW, Sampson HA. Clinical Features of Acute Allergic Reactions to Peanut and Tree Nuts in Children. Pediatrics (1998) 102:e6. doi: 10.1542/peds.102.1.e6

8. Sicherer SH, Furlong TJ, DeSimone J, Sampson HA. The US Peanut and Tree Nut Allergy Registry: Characteristics of Reactions in Schools and Day Care. J Pediatr (2001) 138:560-5. doi: 10.1067/mpd.2001.111821

9. Yu JW, Kagan R, Verreault N, Nicolas N, Joseph L, St Pierre Y, et al. Accidental Ingestions in Children With Peanut Allergy. J Allergy Clin Immunol (2006) 118:466-72. doi: 10.1016/j.jaci.2006.04.024

10. King RM, Knibb RC, Hourihane JO. Impact of Peanut Allergy on Quality of Life, Stress and Anxiety in the Family. Allergy (2009) 64:461-8. doi: 10.1111/ j.1398-9995.2008.01843.x

11. McWilliam V, Koplin J, Lodge C, Tang M, Dharmage S, Allen K. The Prevalence of Tree Nut Allergy: A Systematic Review. Curr Allergy Asthma Rep (2015) 15:54. doi: 10.1007/s11882-015-0555-8 contributed materials. VF, RV, BES, H-JH, MH, BL, MF-T, IS, OE, MK, MF-T, and AA critically read and revised the manuscript. All authors contributed to the article and approved the submitted version.

\section{FUNDING}

Supported by the Danube Allergy Research Cluster funded by the Country of Lower Austria, by the MCCA PhD program of the Austrian Science Fund (FWF), by the Russian Academic Excellence Project 5-100, by a Megagrant of the Government of the Russian Federation, grant No 14.W03.31.0024, by a research grant from Worg Pharmaceuticals, Hangzhou, China and by grant from HVD Life Science, Vienna, Austria.

\section{ACKNOWLEDGMENTS}

The authors acknowledge the support of the Medical University of Vienna, Austria for the research infrastructure.

12. Han Y, Kim J, Ahn K. Food Allergy. Korean J Pediatr (2012) 55:153-8 doi: $10.3345 / \mathrm{kjp} .2012 .55 .5 .153$

13. Valenta R, Hochwallner H, Linhart B, Pahr S. Food Allergies: The Basics. Gastroenterology (2015) 148:1120-31.e4. doi: 10.1053/j.gastro.2015.02.006

14. Astwood JD, Leach JN, Fuchs RL. Stability of Food Allergens to Digestion In Vitro. Nat Biotechnol (1996) 14:1269-73. doi: 10.1038/nbt1096-1269

15. Brough HA, Nadeau KC, Sindher SB, Alkotob SS, Chan S, Bahnson HT, et al. Epicutaneous Sensitization in the Development of Food Allergy: What is the Evidence and How can This be Prevented? Allergy (2020) 75:2185-205. doi: $10.1111 /$ all.14304

16. Campana R, Moritz K, Neubauer A, Huber H, Henning R, Brodie TM, et al. Epicutaneous Allergen Application Preferentially Boosts Specific T Cell Responses in Sensitized Patients. Sci Rep (2017) 7:11657. doi: 10.1038/ s41598-017-10278-1

17. Lin J, Sampson HA. The Role of Immunoglobulin E-Binding Epitopes in the Characterization of Food Allergy. Curr Opin Allergy Clin Immunol (2009) 9:357-63. doi: 10.1097/ACI.0b013e32832d05ba

18. Burks AW, Shin D, Cockrell G, Stanley JS, Helm RM, Bannon GA. Mapping and Mutational Analysis of the IgE-Binding Epitopes on Ara H 1, a Legume Vicilin Protein and a Major Allergen in Peanut Hypersensitivity. Eur J Biochem (1997) 245:334-9. doi: 10.1111/j.1432-1033.1997.t01-1-00334.x

19. Stanley JS, King N, Burks AW, Huang SK, Sampson H, Cockrell G, et al. Identification and Mutational Analysis of the Immunodominant IgE Binding Epitopes of the Major Peanut Allergen Ara H 2. Arch Biochem Biophys (1997) 342:244-53. doi: 10.1006/abbi.1997.9998

20. Stiefel G, Anagnostou K, Boyle RJ, Brathwaite N, Ewan P, Fox AT, et al. BSACI Guideline for the Diagnosis and Management of Peanut and Tree Nut Allergy. Clin Exp Allergy (2017) 47:719-39. doi: 10.1111/cea.12957

21. Cetinkaya PG, Buyuktiryaki B, Soyer O, Sahiner UM, Sekerel BE. Factors Predicting Anaphylaxis in Children With Tree Nut Allergies. Allergy Asthma Proc (2019) 40:180-6. doi: 10.2500/aap.2019.40.4211

22. Breiteneder H, Pettenburger K, Bito A, Valenta R, Kraft D, Rumpold H, et al. The Gene Coding for the Major Birch Pollen Allergen Betv1, is Highly Homologous to a Pea Disease Resistance Response Gene. EMBO J (1989) 8:1935-8. doi: 10.1002/j.1460-2075.1989.tb03597.x

23. Valenta R, Duchêne M, Pettenburger K, Sillaber C, Valent P, Bettelheim P, et al. Identification of Profilin as a Novel Pollen Allergen; IgE Autoreactivity in Sensitized Individuals. Science (1991) 253:557-60. doi: 10.1126/ science. 1857985 
24. Valenta R, Duchene M, Ebner C, Valent P, Sillaber C, Deviller P, et al. Profilins Constitute a Novel Family of Functional Plant Pan-Allergens. J Exp Med (1992) 175:377-85. doi: 10.1084/jem.175.2.377

25. Valenta R, Ferreira F, Grote M, Swoboda I, Vrtala S, Duchêne M, et al. Identification of Profilin as an Actin-Binding Protein in Higher Plants. J Biol Chem (1993) 268:22777-81. doi: 10.1016/S0021-9258(18)41594-3

26. Valenta R, Kraft D. Type I Allergic Reactions to Plant-Derived Food: A Consequence of Primary Sensitization to Pollen Allergens. J Allergy Clin Immunol (1996) 97:893-5. doi: 10.1016/s0091-6749(96)80062-5

27. Kim M, Ahn Y, Yoo Y, Kim DK, Yang HJ, Park HS, et al. Clinical Manifestations and Risk Factors of Anaphylaxis in Pollen-Food Allergy Syndrome. Yonsei Med J (2019) 60:960-8. doi: 10.3349/ymj.2019.60.10.960

28. Reekers R, Busche M, Wittmann M, Kapp A, Werfel T. Birch Pollen-Related Foods Trigger Atopic Dermatitis in Patients With Specific Cutaneous T-Cell Responses to Birch Pollen Antigens. J Allergy Clin Immunol (1999) 104:46672. doi: 10.1016/S0091-6749(99)70395-7

29. Wassmann-Otto A, Heratizadeh A, Wichmann K, Werfel T. Birch PollenRelated Foods can Cause Late Eczematous Reactions in Patients With Atopic Dermatitis. Allergy (2018) 73:2046-54. doi: 10.1111/all.13454

30. Letner D, Farris A, Khalili H, Garber J. Pollen-Food Allergy Syndrome is a Common Allergic Comorbidity in Adults With Eosinophilic Esophagitis. Dis Esophagus (2018) 31. doi: 10.1093/dote/dox122

31. Spergel J, Aceves SS. Allergic Components of Eosinophilic Esophagitis. J Allergy Clin Immunol (2018) 142:1-8. doi: 10.1016/j.jaci.2018.05.001

32. Valenta R, Karaulov A, Niederberger V, Gattinger P, van Hage M, Flicker S, et al. Molecular Aspects of Allergens and Allergy. Adv Immunol (2018) 138:195-256. doi: 10.1016/bs.ai.2018.03.002

33. Vrtala S, Hirtenlehner K, Vangelista L, Pastore A, Eichler HG, Sperr WR, et al. Conversion of the Major Birch Pollen Allergen, Bet V 1, Into Two Nonanaphylactic T Cell Epitope-Containing Fragments: Candidates for a Novel Form of Specific Immunotherapy. J Clin Invest (1997) 99:1673-81. doi: 10.1172/JCI119330

34. Bohle B, Zwölfer B, Heratizadeh A, Jahn-Schmid B, Antonia YD, Alter M, et al. Cooking Birch Pollen-Related Food: Divergent Consequences for IgEand T Cell-Mediated Reactivity In Vitro and In Vivo. J Allergy Clin Immunol (2006) 118:242-9. doi: 10.1016/j.jaci.2006.03.011

35. Kazemi-Shirazi L, Pauli G, Purohit A, Spitzauer S, Fröschlc R, HoffmannSommergruber K, et al. Quantitative IgE Inhibition Experiments With Purified Recombinant Allergens Indicate Pollen-Derived Allergens as the Sensitizing Agents Responsible for Many Forms of Plant Food Allergy. J Allergy Clin Immunol (2000) 105:116-25. doi: 10.1016/S0091-6749(00) 90186-6

36. Fritsch R, Bohle B, Vollmann U, Wiedermann U, Jahn-Schmid B, Krebitz M, et al. Bet V 1, the Major Birch Pollen Allergen, and Mal D 1, the Major Apple Allergen, Cross-React at the Level of Allergen-Specific T Helper Cells. J Allergy Clin Immunol (1998) 102:679-86. doi: 10.1016/s0091-6749(98)70287-8

37. Westman M, Lupinek C, Bousquet J, Andersson N, Pahr S, Baar A, et al. Early Childhood IgE Reactivity to Pathogenesis-Related Class 10 Proteins Predicts Allergic Rhinitis in Adolescence. J Allergy Clin Immunol (2015) 135:1199-206.e1-11. doi: 10.1016/j.jaci.2014.10.042

38. Elisyutina O, Lupinek C, Fedenko E, Litovkina A, Smolnikov E, Ilina N, et al. IgE-Reactivity Profiles to Allergen Molecules in Russian Children With and Without Symptoms of Allergy Revealed by Micro-Array Analysis. Pediatr Allergy Immunol (2021) 32:251-63. doi: 10.1111/pai.13354

39. Elisyutina O, Fedenko E, Campana R, Litovkina A, Ilina N, Kudlay D, et al. Bet V 1-Specific IgE Levels and PR-10 Reactivity Discriminate Silent Sensitization From Phenotypes of Birch Allergy. Allergy (2019) 74:2525-8. doi: 10.1111/all.13931

40. Bucher X, Pichler WJ, Dahinden CA, Helbling A. Effect of Tree Pollen Specific, Subcutaneous Immunotherapy on the Oral Allergy Syndrome to Apple and Hazelnut. Allergy (2004) 59:1272-6. doi: 10.1111/j.13989995.2004.00626.x

41. Niederberger V, Reisinger J, Valent P, Krauth MT, Pauli G, van Hage M, et al. Vaccination With Genetically Modified Birch Pollen Allergens: Immune and Clinical Effects on Oral Allergy Syndrome. J Allergy Clin Immunol (2007) 119:1013-6. doi: 10.1016/j.jaci.2006.12.661

42. Boyce JA, Assa'ad A, Burks AW, Jones SM, Sampson HA, Wood RA, et al. Guidelines for the Diagnosis and Management of Food Allergy in the United
States: Report of the NIAID-Sponsored Expert Panel. J Allergy Clin Immunol (2010) 126:S1-58. doi: 10.1016/j.jaci.2010.10.007

43. Upton J, Alvaro M, Nadeau K. A Perspective on the Pediatric Death From Oral Food Challenge Reported From the Allergy Vigilance Network. Allergy (2019) 74:1035-6. doi: 10.1111/all.13791

44. Akarsu A, Soyer O, Sahiner UM, Valenta R, Sekerel BE. Improving the Diagnostic Utility of Lip Dose Challenges to Diagnose Tree Nut Allergy. J Allergy Clin Immunol Pract (2021) 9:534-6.e2. doi: 10.1016/j.jaip. 2020.08.061

45. Matricardi PM, Kleine-Tebbe J, Hoffmann HJ, Valenta R, Hilger C, Hofmaier S, et al. EAACI Molecular Allergology User's Guide. Pediatr Allergy Immunol (2016) 27:1-250. doi: 10.1111/pai.12563

46. Du Toit G, Roberts G, Sayre PH, Bahnson HT, Radulovic S, Santos AF, et al. Randomized Trial of Peanut Consumption in Infants at Risk for Peanut Allergy. N Engl J Med (2015) 372:803-13. doi: 10.1056/NEJMoa1414850

47. Tscheppe A, Palmberger D, van Rijt L, Kalic T, Mayr V, Palladino C, et al. Development of a Novel Ara H 2 Hypoallergen With No IgE Binding or Anaphylactogenic Activity. J Allergy Clin Immunol (2020) 145:229-38. doi: 10.1016/j.jaci.2019.08.036

48. Burney P, Summers C, Chinn S, Hooper R, van Ree R, Lidholm J. Prevalence and Distribution of Sensitization to Foods in the European Community Respiratory Health Survey: A EuroPrevall Analysis. Allergy (2010) 65:11828. doi: 10.1111/j.1398-9995.2010.02346.x

49. Osborne NJ, Koplin JJ, Martin PE, Gurrin LC, Lowe AJ, Matheson MC, et al. Prevalence of Challenge-Proven IgE-Mediated Food Allergy Using Population-Based Sampling and Predetermined Challenge Criteria in Infants. J Allergy Clin Immunol (2011) 127:668-76. doi: 10.1016/ j.jaci.2011.01.039

50. Burney PG, Potts J, Kummeling I, Mills EN, Clausen M, Dubakiene R, et al. The Prevalence and Distribution of Food Sensitization in European Adults. Allergy (2014) 69:365-71. doi: 10.1111/all.12341

51. Nwaru BI, Hickstein L, Panesar S, Roberts G, Muraro A, Sheikh A. Prevalence of Common Food Allergies in Europe: A Systematic Review and Meta-Analysis. Allergy (2014) 69:992-1007. doi: 10.1111/all.12423

52. Wollmann E, Hamsten C, Sibanda E, Ochome M, Focke-Tejkl M, Asarnoj A, et al. Natural Clinical Tolerance to Peanut in African Patients is Caused by Poor Allergenic Activity of Peanut IgE. Allergy (2015) 70:638-52. doi: $10.1111 /$ all.12592

53. Venter C, Hasan Arshad S, Grundy J, Pereira B, Bernie Clayton C, Voigt K, et al. Time Trends in the Prevalence of Peanut Allergy: Three Cohorts of Children From the Same Geographical Location in the UK. Allergy (2010) 65:103-8. doi: 10.1111/j.1398-9995.2009.02176.x

54. Hourihane JO, Aiken R, Briggs R, Gudgeon LA, Grimshaw KE, DunnGalvin A, et al. The Impact of Government Advice to Pregnant Mothers Regarding Peanut Avoidance on the Prevalence of Peanut Allergy in United Kingdom Children at School Entry. J Allergy Clin Immunol (2007) 119:1197-202. doi: 10.1016/j.jaci.2006.12.670

55. Nicolaou N, Poorafshar M, Murray C, Simpson A, Winell H, Kerry G, et al. Allergy or Tolerance in Children Sensitized to Peanut: Prevalence and Differentiation Using Component-Resolved Diagnostics. J Allergy Clin Immunol (2010) 125:191-7.e1-13. doi: 10.1016/j.jaci.2009.10.008

56. Luyt DK, Vaughan D, Oyewole E, Stiefel G. Ethnic Differences in Prevalence of Cashew Nut, Pistachio Nut and Almond Allergy. Pediatr Allergy Immunol (2016) 27:651-4. doi: 10.1111/pai.12582

57. Du Toit G, Katz Y, Sasieni P, Mesher D, Maleki SJ, Fisher HR, et al. Early Consumption of Peanuts in Infancy is Associated With a Low Prevalence of Peanut Allergy. J Allergy Clin Immunol (2008) 122:984-91. doi: 10.1016/ j.jaci.2008.08.039

58. Osterballe M, Mortz CG, Hansen TK, Andersen KE, Bindslev-Jensen C. The Prevalence of Food Hypersensitivity in Young Adults. Pediatr Allergy Immunol (2009) 20:686-92. doi: 10.1111/j.1399-3038.2008.00842.x

59. Pénard-Morand C, Raherison C, Kopferschmitt C, Caillaud D, Lavaud F, Charpin D, et al. Prevalence of Food Allergy and its Relationship to Asthma and Allergic Rhinitis in Schoolchildren. Allergy (2005) 60:1165-71. doi: 10.1111/j.1398-9995.2005.00860.x

60. Uotila R, Kukkonen AK, Pelkonen AS, Mäkelä MJ. Cross-Sensitization Profiles of Edible Nuts in a Birch-Endemic Area. Allergy (2016) 71:51421. doi: 10.1111 /all.12826 
61. Mustafayev R, Civelek E, Orhan F, Yüksel H, Boz AB, Sekerel BE. Similar Prevalence, Different Spectrum: IgE-Mediated Food Allergy Among Turkish Adolescents. Allergol Immunopathol (Madr) (2013) 41:387-96. doi: 10.1016/ j.aller.2012.05.005

62. Orhan F, Karakas T, Cakir M, Aksoy A, Baki A, Gedik Y. Prevalence of Immunoglobulin E-Mediated Food Allergy in 6-9-Year-Old Urban Schoolchildren in the Eastern Black Sea Region of Turkey. Clin Exp Allergy (2009) 39:1027-35. doi: 10.1111/j.1365-2222.2009.03263.x

63. Kaya A, Erkoçoğlu M, Civelek E, Çakır B, Kocabaş CN. Prevalence of Confirmed IgE-Mediated Food Allergy Among Adolescents in Turkey. Pediatr Allergy Immunol (2013) 24:456-62. doi: 10.1111/pai.12097

64. Noorbakhsh R, Mortazavi SA, Sankian M, Shahidi F, Tehrani M, Azad FJ, et al. Pistachio Allergy-Prevalence and In Vitro Cross-Reactivity With Other Nuts. Allergol Int (2011) 60:425-32. doi: 10.2332/allergolint.10-OA-0222

65. Khazaei HA, Hashemi SR, Aghamohammadi A, Farhoudi F, Rezaei N. The Study of Type 1 Allergy Prevalence Among People of South-East of Iran by Skin Prick Test Using Common Allergens. Iran J Allergy Asthma Immunol (2003) 2:165-8.

66. Jeong K, Lee SY, Ahn K, Kim J, Lee HR, Suh DI, et al. A Multicenter Study on Anaphylaxis Caused by Peanut, Tree Nuts, and Seeds in Children and Adolescents. Allergy (2017) 72:507-10. doi: 10.1111/all.13096

67. Sun X, Zhao J, Wang Q, Shi G, Yang J, Ming L. Prevalence of Allergen Sensitization Among 15,534 Patients With Suspected Allergic Diseases in Henan Province, China. Asian Pac J Allergy Immunol (2019) 37:57-64. doi: 10.12932/AP-160817-0137

68. Chen J, Hu Y, Allen KJ, Ho MH, Li H. The Prevalence of Food Allergy in Infants in Chongqing, China. Pediatr Allergy Immunol (2011) 22:356-60. doi: 10.1111/j.1399-3038.2011.01139.x

69. Hu Y, Chen J, Li H. Comparison of Food Allergy Prevalence Among Chinese Infants in Chongqing, 2009 Versus 1999. Pediatr Int (2010) 52:820-4. doi: 10.1111/j.1442-200X.2010.03166.x

70. Lee MP, Saffari SE, Loh W, Goh SH, Goh A, Chiang WC, et al. A 5-Year Retrospective Review of Children With Peanut Allergy in the Largest Paediatric Hospital in Singapore. Asia Pac Allergy (2020) 10:e6. doi: 10.5415/apallergy.2020.10.e6

71. Shek LP, Cabrera-Morales EA, Soh SE, Gerez I, Ng PZ, Yi FC, et al. A Population-Based Questionnaire Survey on the Prevalence of Peanut, Tree Nut, and Shellfish Allergy in 2 Asian Populations. J Allergy Clin Immunol (2010) 126:324-31. doi: 10.1016/j.jaci.2010.06.003

72. Chiang WC, Pons L, Kidon MI, Liew WK, Goh A, Burks AW. Serological and Clinical Characteristics of Children With Peanut Sensitization in an Asian Community. Pediatr Allergy Immunol (2010) 21:e429-38. doi: 10.1111/j.1399-3038.2009.00930.x

73. Liew WK, Chiang WC, Goh AE, Lim HH, Chay OM, Chang S, et al. Paediatric Anaphylaxis in a Singaporean Children Cohort: Changing Food Allergy Triggers Over Time. Asia Pac Allergy (2013) 3:29-34. doi: 10.5415/ apallergy.2013.3.1.29

74. Cheng CW, Lin YC, Nong BR, Liu PY, Huang YF, Lu LY, et al. Nut Sensitization Profile in Southern Taiwan. J Microbiol Immunol Infect (2020) 53:791-6. doi: 10.1016/j.jmii.2018.12.005

75. Imamura T, Kanagawa Y. Ebisawa M. A Survey of Patients With SelfReported Severe Food Allergies in Japan. Pediatr Allergy Immunol (2008) 19:270-4. doi: 10.1111/j.1399-3038.2007.00621.x

76. Sicherer SH, Muñoz-Furlong A, Godbold JH, Sampson HA. US Prevalence of Self-Reported Peanut, Tree Nut, and Sesame Allergy: 11-Year Follow-Up. J Allergy Clin Immunol (2010) 125:1322-6. doi: 10.1016/j.jaci.2010.03.029

77. Sicherer SH, Muñoz-Furlong A, Burks AW, Sampson HA. Prevalence of Peanut and Tree Nut Allergy in the US Determined by a Random Digit Dial Telephone Survey. J Allergy Clin Immunol (1999) 103:559-62. doi: 10.1016/ s0091-6749(99)70224-1

78. Sicherer SH, Muñoz-Furlong A, Sampson HA. Prevalence of Peanut and Tree Nut Allergy in the United States Determined by Means of a Random Digit Dial Telephone Survey. J Allergy Clin Immunol (2003) 112:1203-7. doi: 10.1016/S0091-6749(03)02026-8

79. Ruiz Segura LT, Figueroa Pérez E, Nowak-Wegrzyn A, Siepmann T, Larenas-Linnemann D. Food Allergen Sensitization Patterns in a Large Allergic Population in Mexico. Allergol Immunopathol (Madr) (2020) 48:553-9. doi: 10.1016/j.aller.2020.02.004
80. Bedolla-Barajas M, Bedolla-Pulido TR, Macriz-Romero N, Morales-Romero J, Robles-Figueroa M. Prevalence of Peanut, Tree Nut, Sesame, and Seafood Allergy in Mexican Adults. Rev Invest Clin (2015) 67:379-86.

81. Ben-Shoshan M, Harrington DW, Soller L, Fragapane J, Joseph L, St Pierre Y, et al. A Population-Based Study on Peanut, Tree Nut, Fish, Shellfish, and Sesame Allergy Prevalence in Canada. J Allergy Clin Immunol (2010) 125:1327-35. doi: 10.1016/j.jaci.2010.03.015

82. McWilliam V, Peters R, Tang ML, Dharmage S, Ponsonby AL, Gurrin L, et al. Patterns of Tree Nut Sensitization and Allergy in the First 6 Years of Life in a Population-Based Cohort. J Allergy Clin Immunol (2019) 143:644650.e5. doi: 10.1016/j.jaci.2018.07.038

83. Sasaki M, Koplin JJ, Dharmage SC, Field MJ, Sawyer SM, McWilliam V, et al. Prevalence of Clinic-Defined Food Allergy in Early Adolescence: The SchoolNuts Study. J Allergy Clin Immunol (2018) 141:391-398.e4. doi: 10.1016/j.jaci.2017.05.041

84. Mittermann I, Dzoro S, Gattinger P, Botha M, Basera W, Facey-Thomas HE, et al. Molecular IgE Sensitization Profiles of Urban and Rural Children in South Africa. Pediatr Allergy Immunol (2021) 32:234-41. doi: 10.1111/ pai. 13377

85. Vetander M, Helander D, Flodström C, Ostblom E, Alfvén T, Ly DH, et al. Anaphylaxis and Reactions to Foods in Children-a Population-Based Case Study of Emergency Department Visits. Clin Exp Allergy (2012) 42:568-77. doi: 10.1111/j.1365-2222.2011.03954.x

86. Soto-Quiros M, Gutierrez I, Calvo N, Araya C, Karlberg J, Hanson LA, et al. Allergen Sensitization of Asthmatic and Nonasthmatic Schoolchildren in Costa Rica. Allergy (1998) 53:1141-7. doi: 10.1111/j.1398-9995. 1998.tb03833.x

87. Martínez J, Méndez C, Talesnik E, Campos E, Viviani P, Sánchez I. Pruebas Cutáneas De Hipersensibilidad Inmediata En Una Población Pediátrica Seleccionada. Rev Med Chil (2005) 133:195-201. doi: 10.4067/s003498872005000200007

88. Rodríguez-Ortiz PG, Muñoz-Mendoza D, Arias-Cruz A, González-Díaz SN, Herrera-Castro D, Vidaurri-Ojeda AC. Características Epidemiológicas De Pacientes Con Alergia a Alimentos Atendidos En El Centro Regional De Alergias E Inmunologia Clínica De Monterrey. Rev Alerg Mex (2009) 56:185-91.

89. Chen J, Liao Y, Zhang H, Zhao H, Chen J, Li H. Prevalence of Food Allergy in Children Under 2 Years of Age in Three Cities in China. Zhonghua Er Ke Za Zhi (2012) 50:5-9.

90. Lee AJ, Thalayasingam M, Lee BW. Food Allergy in Asia: How Does it Compare? Asia Pac Allergy (2013) 3:3-14. doi: 10.5415/apallergy.2013.3.1.3

91. Venter C, Maslin K, Patil V, Kurukulaaratchy R, Grundy J, Glasbey G, et al. The Prevalence, Natural History and Time Trends of Peanut Allergy Over the First 10 Years of Life in Two Cohorts Born in the Same Geographical Location 12 Years Apart. Pediatr Allergy Immunol (2016) 27:804-11. doi: 10.1111/pai.12616

92. Kim M, Lee JY, Jeon HY, Yang HK, Lee KJ, Han Y, et al. Prevalence of Immediate-Type Food Allergy in Korean Schoolchildren in 2015: A Nationwide, Population-Based Study. Allergy Asthma Immunol Res (2017) 9:410-6. doi: 10.4168/aair.2017.9.5.410

93. Peters RL, Koplin JJ, Gurrin LC, Dharmage SC, Wake M, Ponsonby AL, et al. The Prevalence of Food Allergy and Other Allergic Diseases in Early Childhood in a Population-Based Study: HealthNuts Age 4-Year FollowUp. J Allergy Clin Immunol (2017) 140:145-153.e8. doi: 10.1016/ j.jaci.2017.02.019

94. Vereda A, van Hage M, Ahlstedt S, Ibañez MD, Cuesta-Herranz J, van Odijk J, et al. Peanut Allergy: Clinical and Immunologic Differences Among Patients From 3 Different Geographic Regions. J Allergy Clin Immunol (2011) 127:603-7. doi: 10.1016/j.jaci.2010.09.010

95. Asarnoj A, Movérare R, Ostblom E, Poorafshar M, Lilja G, Hedlin G, et al. IgE to Peanut Allergen Components: Relation to Peanut Symptoms and Pollen Sensitization in 8-Year-Olds. Allergy (2010) 65:1189-95. doi: 10.1111/ j.1398-9995.2010.02334.x

96. Asarnoj A, Hamsten C, Lupinek C, Melén E, Andersson N, Anto JM, et al. Prediction of Peanut Allergy in Adolescence by Early Childhood Storage Protein-Specific IgE Signatures: The BAMSE Population-Based Birth Cohort. J Allergy Clin Immunol (2017) 140:587-590.e7. doi: 10.1016/ j.jaci.2016.12.973 
97. Allergen Nomenclature, the Official Site for the Systematic Allergen Nomenclature (2021). Available at: http://www.allergen.org.

98. Burks AW, Cockrell G, Stanley JS, Helm RM, Bannon GA. Recombinant Peanut Allergen Ara H I Expression and IgE Binding in Patients With Peanut Hypersensitivity. J Clin Invest (1995) 96:1715-21. doi: 10.1172/ JCI118216

99. Clarke MC, Kilburn SA, Hourihane JO, Dean KR, Warner JO, Dean TP. Serological Characteristics of Peanut Allergy. Clin Exp Allergy (1998) 28:1251-7. doi: 10.1046/j.1365-2222.1998.00386.x

100. Kleber-Janke T, Crameri R, Appenzeller U, Schlaak M, Becker WM. Selective Cloning of Peanut Allergens, Including Profilin and 2S Albumins, by Phage Display Technology. Int Arch Allergy Immunol (1999) 119:265-74. doi: $10.1159 / 000024203$

101. Burks AW, Williams LW, Connaughton C, Cockrell G, O’Brien TJ, Helm RM, et al. Identification and Characterization of a Second Major Peanut Allergen, Ara $h$ II, With Use of the Sera of Patients With Atopic Dermatitis and Positive Peanut Challenge. J Allergy Clin Immunol (1992) 90:962-9. doi: 10.1016/0091-6749(92)90469-i

102. Koppelman SJ, Wensing M, Ertmann M, Knulst AC, Knol EF. Relevance of Ara H1, Ara H2 and Ara H3 in Peanut-Allergic Patients, as Determined by Immunoglobulin E Western Blotting, Basophil-Histamine Release and Intracutaneous Testing: Ara $\mathrm{H} 2$ is the Most Important Peanut Allergen. Clin Exp Allergy (2004) 34:583-90. doi: 10.1111/j.1365-2222.2004.1923.x

103. Kukkonen AK, Pelkonen AS, Mäkinen-Kiljunen S, Voutilainen H, Mäkelä MJ. Ara H 2 and Ara 6 Are the Best Predictors of Severe Peanut Allergy: A Double-Blind Placebo-Controlled Study. Allergy (2015) 70:1239-45. doi: $10.1111 /$ all.12671

104. Valcour A, Jones JE, Lidholm J, Borres MP, Hamilton RG. Sensitization Profiles to Peanut Allergens Across the United States. Ann Allergy Asthma Immunol (2017) 119:262-266.e1. doi: 10.1016/j.anai.2017.06.021

105. Rabjohn P, Helm EM, Stanley JS, West CM, Sampson HA, Burks AW, et al. Molecular Cloning and Epitope Analysis of the Peanut Allergen Ara H 3. J Clin Invest (1999) 103:535-42. doi: 10.1172/JCI5349

106. Cabanos C, Tandang-Silvas, Odijk V, Brostedt P, Tanaka A, Utsumi S, et al. Expression, Purification, Cross-Reactivity and Homology Modeling of Peanut Profilin. Protein Expr Purif (2010) 73:36-45. doi: 10.1016/ j.pep.2010.03.005

107. Schmidt H, Krause S, Gelhaus C, Petersen A, Janssen O, Becker WM. Detection and Structural Characterization of Natural Ara H 7, the Third Peanut Allergen of the 2S Albumin Family. J Proteome Res (2010) 9:3701-9. doi: $10.1021 /$ pr1002406

108. Blankestijn MA, Otten HG, Suer W, Weimann A, Knol EF, Knulst AC. Specific IgE to Peanut 2 S Albumin Ara H 7 has a Discriminative Ability Comparable to Ara H 2 and 6. Clin Exp Allergy (2018) 48:60-5. doi: 10.1111/ cea. 13030

109. Mittag D, Akkerdaas J, Ballmer-Weber BK, Vogel L, Wensing M, WM B, et al. Ara H 8, a Bet V 1-Homologous Allergen From Peanut, Is a Major Allergen in Patients With Combined Birch Pollen and Peanut Allergy. J Allergy Clin Immunol (2004) 114:1410-7. doi: 10.1016/j.jaci.2004.09.014

110. Krause S, Reese G, Randow S, Zennaro D, Quaratino D, Palazzo P, et al. Lipid Transfer Protein (Ara H 9) as a New Peanut Allergen Relevant for a Mediterranean Allergic Population. J Allergy Clin Immunol (2009) 124:771-778.e5. doi: 10.1016/j.jaci.2009.06.008

111. Lauer I, Dueringer N, Pokoj S, Rehm S, Zoccatelli G, Reese G, et al. The nonSpecific Lipid Transfer Protein, Ara H 9, is an Important Allergen in Peanut. Clin Exp Allergy (2009) 39:1427-37. doi: 10.1111/j.1365-2222.2009.03312.x

112. Schwager C, Kull S, Krause S, Schocker F, Petersen A, Becker WM, et al. Development of a Novel Strategy to Isolate Lipophilic Allergens (Oleosins) From Peanuts. PloS One (2015) 10:e0123419. doi: 10.1371/journal.pone.0123419

113. Schwager C, Kull S, Behrends J, Röckendorf N, Schocker F, Frey A, et al. Peanut Oleosins Associated With Severe Peanut Allergy-Importance of Lipophilic Allergens for Comprehensive Allergy Diagnostics. J Allergy Clin Immunol (2017) 140:1331-1338.e8. doi: 10.1016/j.jaci.2017.02.020

114. Petersen A, Kull S, Rennert S, Becker WM, Krause S, Ernst M, et al. Peanut Defensins: Novel Allergens Isolated From Lipophilic Peanut Extract. J Allergy Clin Immunol (2015) 136:1295-301. doi: 10.1016/j.jaci.2015.04.010

115. Teuber SS, Dandekar AM, Peterson WR, Sellers CL. Cloning and Sequencing of a Gene Encoding a $2 S$ Albumin Seed Storage Protein Precursor From
English Walnut (Juglans Regia), a Major Food Allergen. J Allergy Clin Immunol (1998) 101:807-14. doi: 10.1016/S0091-6749(98)70308-2

116. Costa J, Carrapatoso I, Oliveira MB, Mafra I. Walnut Allergens: Molecular Characterization, Detection and Clinical Relevance. Clin Exp Allergy (2014) 44:319-41. doi: 10.1111/cea.12267

117. Teuber SS, Jarvis KC, Dandekar AM, Peterson WR, Ansari AA. Identification and Cloning of a Complementary DNA Encoding a VicilinLike Proprotein, Jug R 2, From English Walnut Kernel (Juglans Regia), a Major Food Allergen. J Allergy Clin Immunol (1999) 104:1311-20. doi: 10.1016/s0091-6749(99)70029-1

118. Pastorello EA, Farioli L, Pravettoni V, Robino AM, Scibilia J, Fortunato D, et al. Lipid Transfer Protein and Vicilin are Important Walnut Allergens in Patients Not Allergic to Pollen. J Allergy Clin Immunol (2004) 114:908-14. doi: 10.1016/j.jaci.2004.06.020

119. Teuber SS, Peterson WR, Uratsu S, Dandekar A, Roux KH, Sathe SK. Identification and Cloning of Jug R 4, a Major Food Allergen From English Walnut Belonging to the Legumin Group. J Allergy Clin Immunol (2003) 111:S248. doi: 10.1016/S0091-6749(03)80879-5

120. Wallowitz M, Peterson WR, Uratsu S, Comstock SS, Dandekar AM, Teuber SS. Jug R 4, a Legumin Group Food Allergen From Walnut (Juglans Regia Cv. Chandler). J Agric Food Chem (2006) 54:8369-75. doi: $10.1021 /$ jf061329s

121. Wangorsch A, Jamin A, Lidholm J, Gräni N, Lang C, Ballmer-Weber B, et al. Identification and Implication of an Allergenic PR-10 Protein From Walnut in Birch Pollen Associated Walnut Allergy. Mol Nutr Food Res (2017) 61. doi: 10.1002/mnfr.201600902

122. Dubiela P, Kabasser S, Smargiasso N, Geiselhart S, Bublin M, Hafner C, et al. Jug R 6 is the Allergenic Vicilin Present in Walnut Responsible for IgE CrossReactivities to Other Tree Nuts and Seeds. Sci Rep (2018) 8:11366. doi: 10.1038/s41598-018-29656-4

123. Zhang YZ, Du WX, Fan Y, Yi J, Lyu SC, Nadeau KC, et al. Purification and Characterization of a Black Walnut (Juglans Nigra) Allergen, Jug N 4. J Agric Food Chem (2017) 65:454-62. doi: 10.1021/acs.jafc.6b04387

124. Pastorello EA, Vieths S, Pravettoni V, Farioli L, Trambaioli C, Fortunato D, et al. Identification of Hazelnut Major Allergens in Sensitive Patients With Positive Double-Blind, Placebo-Controlled Food Challenge Results. J Allergy Clin Immunol (2002) 109:563-70. doi: 10.1067/mai.2002.121946

125. Hofmann C, Scheurer S, Rost K, Graulich E, Jamin A, Foetisch K, et al. Cor a 1-Reactive T Cells and IgE are Predominantly Cross-Reactive to Bet V 1 in Patients With Birch Pollen-Associated Food Allergy to Hazelnut. J Allergy Clin Immunol (2013) 131:1384-92.e6. doi: 10.1016/j.jaci.2012.10.037

126. De Knop KJ, Verweij MM, Grimmelikhuijsen M, Philipse E, Hagendorens $\mathrm{MM}$, Bridts $\mathrm{CH}$, et al. Age-Related Sensitization Profiles for Hazelnut (Corylus Avellana) in a Birch-Endemic Region. Pediatr Allergy Immunol (2011) 22:e139-49. doi: 10.1111/j.1399-3038.2011.01112.x

127. Hirschwehr R, Valenta R, Ebner C, Ferreira F, Sperr WR, Valent P, et al. Identification of Common Allergenic Structures in Hazel Pollen and Hazelnuts: A Possible Explanation for Sensitivity to Hazelnuts in Patients Allergic to Tree Pollen. J Allergy Clin Immunol (1992) 90:927-36. doi: 10.1016/0091-6749(92)90465-e

128. Schocker F, Lüttkopf D, Scheurer S, Petersen A, Cisteró-Bahima A, Enrique E, et al. Recombinant Lipid Transfer Protein Cor a 8 From Hazelnut: A New Tool for In Vitro Diagnosis of Potentially Severe Hazelnut Allergy. J Allergy Clin Immunol (2004) 113:141-7. doi: 10.1016/j.jaci.2003.09.013

129. Flinterman AE, Akkerdaas JH, den Hartog Jager CF, Rigby NM, FernandezRivas M, Hoekstra MO, et al. Lipid Transfer Protein-Linked Hazelnut Allergy in Children From a non-Mediterranean Birch-Endemic Area. J Allergy Clin Immunol (2008) 121:423-428.e2. doi: 10.1016/j.jaci. 2007.10.009

130. Blanc F, Bernard H, Ah-Leung S, Przybylski-Nicaise L, Skov PS, Purohit A, et al. Further Studies on the Biological Activity of Hazelnut Allergens. Clin Transl Allergy (2015) 5:26. doi: 10.1186/s13601-015-0066-7

131. Beyer K, Grishina G, Bardina L, Grishin A, Sampson HA. Identification of an $11 \mathrm{~S}$ Globulin as a Major Hazelnut Food Allergen in Hazelnut-Induced Systemic Reactions. J Allergy Clin Immunol (2002) 110:517-23. doi: 10.1067/mai.2002.127434

132. Ebo DG, Verweij MM, Sabato V, Hagendorens MM, Bridts CH, De Clerck LS. Hazelnut Allergy: A Multi-Faced Condition With Demographic and 
Geographic Characteristics. Acta Clin Belg (2012) 67:317-21. doi: 10.2143/ ACB.67.5.2062683

133. Gruehn S, Suphioglu C, O’Hehir RE, Volkmann D. Molecular Cloning and Characterization of Hazel Pollen Protein $(70 \mathrm{Kd})$ as a Luminal Binding Protein (BiP): A Novel Cross-Reactive Plant Allergen. Int Arch Allergy Immunol (2003) 131:91-100. doi: 10.1159/000070924

134. Lauer I, Foetisch K, Kolarich D, Ballmer-Weber BK, Conti A, Altmann F, et al. Hazelnut (Corylus Avellana) Vicilin Cor a 11: Molecular Characterization of a Glycoprotein and its Allergenic Activity. Biochem J (2004) 383:327-34. doi: 10.1042/BJ20041062

135. Verweij MM, Hagendorens MM, Trashin S, Cucu T, De Meulenaer B, Devreese B, et al. Age-Dependent Sensitization to the 7S-Vicilin-Like Protein Cor a 11 From Hazelnut (Corylus Avellana) in a Birch-Endemic Region. J Investig Allergol Clin Immunol (2012) 22:245-51.

136. Zuidmeer-Jongejan L, Fernández-Rivas M, Winter MG, Akkerdaas JH, Summers C, Lebens A, et al. Oil Body-Associated Hazelnut Allergens Including Oleosins are Underrepresented in Diagnostic Extracts But Associated With Severe Symptoms. Clin Transl Allergy (2014) 4:4. doi: 10.1186/2045-7022-4-4

137. Garino C, Zuidmeer L, Marsh J, Lovegrove A, Morati M, Versteeg S, et al. Isolation, Cloning, and Characterization of the 2S Albumin: A New Allergen From Hazelnut. Mol Nutr Food Res (2010) 54:1257-65. doi: 10.1002/ mnfr.200900456

138. Masthoff LJ, Mattsson L, Zuidmeer-Jongejan L, Lidholm J, Andersson K, Akkerdaas JH, et al. Sensitization to Cor a 9 and Cor a 14 is Highly Specific for a Hazelnut Allergy With Objective Symptoms in Dutch Children and Adults. J Allergy Clin Immunol (2013) 132:393-9. doi: 10.1016/ j.jaci.2013.02.024

139. Faber MA, De Graag M, van der Heijden C, Sabato V, Hagendorens MM, Bridts CH, et al. Cor a 14: Missing Link in the Molecular Diagnosis of Hazelnut Allergy? Int Arch Allergy (2014) 164:200-6. doi: 10.1159/ 000365050

140. Ahn K, Bardina L, Grishina G, Beyer K, Sampson HA. Identification of Two Pistachio Allergens, Pis V 1 and Pis V 2, Belonging to the $2 S$ Albumin and 11S Globulin Family. Clin Exp Allergy (2009) 39:926-34. doi: 10.1111/j.13652222.2009.03259.x

141. Willison LN, Tawde P, Robotham JM, Penney RM, Teuber SS, Sathe SK, et al. Pistachio Vicilin, Pis V 3, is Immunoglobulin E-Reactive and Cross-Reacts With the Homologous Cashew Allergen, Ana O 1. Clin Exp Allergy (2008) 38:1229-38. doi: 10.1111/j.1365-2222.2008.02998.x

142. Ayuso R, Grishina G, Ahn K, Bardina L, Beyer K, Sampson H. Identification of a MnSOD-Like Protein as a New Major Pistachio Allergen. J Allergy Clin Immunol (2007) 119:S115. doi: 10.1016/j.jaci.2006.11.433

143. Noorbakhsh R, Mortazavi SA, Sankian M, Shahidi F, Assarehzadegan MA, Varasteh A. Cloning, Expression, Characterization, and Computational Approach for Cross-Reactivity Prediction of Manganese Superoxide Dismutase Allergen From Pistachio Nut. Allergol Int (2010) 59:295-304. doi: 10.2332/allergolint.10-OA-0174

144. Willison LN, Sathe SK, Roux KH. Production and Analysis of Recombinant Tree Nut Allergens. Methods (2014) 66:34-43. doi: 10.1016/j.ymeth.2013.07.033

145. Wang F, Robotham JM, Teuber SS, Tawde P, Sathe SK, Roux KH. Ana O 1, a Cashew (Anacardium Occidental) Allergen of the Vicilin Seed Storage Protein Family. J Allergy Clin Immunol (2002) 110:160-6. doi: 10.1067/ mai.2002.125208

146. Wang F, Robotham JM, Teuber SS, Sathe SK, Roux KH. Ana O 2, a Major Cashew (Anacardium Occidentale L.) Nut Allergen of the Legumin Family. Int Arch Allergy Immunol (2003) 132:27-39. doi: 10.1159/000073262

147. Robotham JM, Wang F, Seamon V, Teuber SS, Sathe SK, Sampson HA, et al. Ana O 3, an Important Cashew Nut (Anacardium Occidentale L.) Allergen of the 2S Albumin Family. J Allergy Clin Immunol (2005) 115:1284-90. doi: 10.1016/j.jaci.2005.02.028

148. Tawde P, Venkatesh YP, Wang F, Teuber SS, Sathe SK, Roux KH. Cloning and Characterization of Profilin (Pru Du 4), a Cross-Reactive Almond (Prunus Dulcis) Allergen. J Allergy Clin Immunol (2006) 118:915-22. doi: 10.1016/j.jaci.2006.05.028

149. Abolhassani M, Roux KH. cDNA Cloning, Expression and Characterization of an Allergenic 60s Ribosomal Protein of Almond (Prunus Dulcis). Iran J Allergy Asthma Immunol (2009) 8:77-84.
150. Sathe SK, Wolf WJ, Roux KH, Teuber SS, Venkatachalam M, Sze-Tao KW. Biochemical Characterization of Amandin, the Major Storage Protein in Almond (Prunus Dulcis L.). J Agric Food Chem (2002) 50:4333-41. doi: $10.1021 / \mathrm{jf} 020007 \mathrm{v}$

151. Willison LN, Tripathi P, Sharma G, Teuber SS, Sathe SK, Roux KH. Cloning, Expression and Patient IgE Reactivity of Recombinant Pru Du 6, an 11S Globulin From Almond. Int Arch Allergy Immunol (2011) 156:267-81. doi: $10.1159 / 000323887$

152. Kabasser S, Hafner C, Chinthrajah S, Sindher SB, Kumar D, Kost LE, et al. Identification of Pru Du 6 as a Potential Marker Allergen for Almond Allergy. Allergy (2020) 76:1463-72. doi: 10.1111/all.14613

153. Che H, Zhang Y, Jiang S, Jin T, Lyu SC, Nadeau KC, et al. Almond (Prunus Dulcis) Allergen Pru Du 8, the First Member of a New Family of Food Allergens. J Agric Food Chem (2019) 67:8626-31. doi: 10.1021/ acs.jafc. 9 b02781

154. Pastorello EA, Farioli L, Pravettoni V, Ispano M, Conti A, Ansaloni R, et al. Sensitization to the Major Allergen of Brazil Nut is Correlated With the Clinical Expression of Allergy. J Allergy Clin Immunol (1998) 102:1021-7. doi: 10.1016/S0091-6749(98)70341-0

155. Alcocer MJ, Murtagh GJ, Bailey K, Dumoulin M, Meseguer AS, Parker MJ, et al. The Disulphide Mapping, Folding and Characterisation of Recombinant Ber E 1, an Allergenic Protein, and SFA8, Two Sulphur-Rich 2S Plant Albumins. J Mol Biol (2002) 324:165-75. doi: 10.1016/S0022-2836 (02)01061-6

156. Guo F, Jin T, Howard A, Zhang YZ. Purification, Crystallization and Initial Crystallographic Characterization of Brazil-Nut Allergen Ber E 2. Acta Cryst F (2007) 63:976-9. doi: 10.1107/S1744309107051445

157. Beyer K, Bardina L, Grishina G, Ashraf A, Teuber S, Niggemann B, et al. Identification of a New Brazil Nut Allergen - Ber E 2. J Allergy Clin Immunol (2008) 121:247. doi: 10.1016/j.jaci.2007.12.980

158. Sharma GM, Irsigler A, Dhanarajan P, Ayuso R, Bardina L, Sampson HA, et al. Cloning and Characterization of $2 S$ Albumin, Car I 1, a Major Allergen in Pecan. J Agric Food Chem (2011) 59:4130-9. doi: 10.1021/jf104319d

159. Zhang Y, Lee B, Du WX, Lyu SC, Nadeau KC, Grauke LJ, et al. Identification and Characterization of a New Pecan [Carya Illinoinensis (Wangenh.) K. Koch] Allergen, Car I 2. J. Agric Food Chem (2016) 64:4146-51. doi: 10.1021/ acs.jafc.6b00884

160. Sharma GM, Irsigler A, Dhanarajan P, Ayuso R, Bardina L, Sampson HA, et al. Cloning and Characterization of an 11S Legumin, Car I 4, a Major Allergen in Pecan. J Agric Food Chem (2011) 59:9542-52. doi: 10.1021/ if 2017447

161. Morales M, López-Matas MÁ, Moya R, Carnés J. Cross-Reactivity Among non-Specific Lipid-Transfer Proteins From Food and Pollen Allergenic Sources. Food Chem (2014) 165:397-402. doi: 10.1016/j.foodchem. 2014.05.101

162. Hemmings O, Du Toit G, Radulovic S, Lack G, F. Santos A. Ara H 2 is the Dominant Peanut Allergen Despite Similarities With Ara H 6. J Allergy Clin Immunol (2020) 146:621-630.e5. doi: 10.1016/j.jaci.2020.03.026

163. Asarnoj A, Glaumann S, Elfström L, Lilja G, Lidholm J, Nilsson C, et al. Anaphylaxis to Peanut in a Patient Predominantly Sensitized to Ara H 6. Int Arch Allergy Immunol (2012) 159:209-12. doi: 10.1159/000336027

164. Codreanu F, Collignon O, Roitel O, Thouvenot B, Sauvage C, Vilain A-C, et al. A Novel Immunoassay Using Recombinant Allergens Simplifies Peanut Allergy Diagnosis. Int Arch Allergy Immunol (2011) 154:216-26. doi: $10.1159 / 000321108$

165. Ballmer-Weber BK, Lidholm J, Fernández-Rivas M, Seneviratne S, Hanschmann KM, Vogel L, et al. IgE Recognition Patterns in Peanut Allergy are Age Dependent: Perspectives of the EuroPrevall Study. Allergy (2015) 70:391-407. doi: 10.1111/all.12574

166. Maleki SJ, Chung SY, Champagne ET, Raufman JP. The Effects of Roasting on the Allergenic Properties of Peanut Proteins. J Allergy Clin Immunol (2000) 106:763-8. doi: 10.1067/mai.2000.109620

167. Beyer K, Morrow E, Li XM, Bardina L, Bannon GA, Burks A, et al. Effects of Cooking Methods on Peanut Allergenicity. J Allergy Clin Immunol (2001) 107:1077-81. doi: 10.1067/mai.2001.115480

168. Mondoulet L, Paty E, Drumare MF, Ah-Leung S, Scheinmann P, Willemot RM, et al. Influence of Thermal Processing on the Allergenicity of Peanut Proteins. J Agric Food Chem (2005) 53:4547-53. doi: 10.1021/jf050091p 
169. Vissers YM, Blanc F, Skov PS, Johnson PE, Rigby NM, Przybylski-Nicaise L, et al. Effect of Heating and Glycation on the Allergenicity of $2 S$ Albumins (Ara H 2/6) From Peanut. PloS One (2011) 6:e23998. doi: 10.1371/ journal.pone. 0023998

170. Buyuktiryaki B, Cavkaytar O, Sahiner UM, Yilmaz EA, Yavuz ST, Soyer O, et al. Cor a 14, Hazelnut-Specific IgE, and SPT as a Reliable Tool in Hazelnut Allergy Diagnosis in Eastern Mediterranean Children. J Allergy Clin Immunol Pract (2016) 4:265-72.e3. doi: 10.1016/j.jaip.2015.12.012

171. Akkerdaas JH, Schocker F, Vieths S, Versteeg S, Zuidmeer L, Hefle SL, et al. Cloning of Oleosin, a Putative New Hazelnut Allergen, Using a Hazelnut cDNA Library. Mol Nutr Food Res (2006) 50:18-23. doi: 10.1002/mnfr.200500147

172. Datema MR, Zuidmeer-Jongejan L, Asero R, Barreales L, Belohlavkova S, de Blay F, et al. Hazelnut Allergy Across Europe Dissected Molecularly: A EuroPrevall Outpatient Clinic Survey. J Allergy Clin Immunol (2015) 136:382-91. doi: 10.1016/j.jaci.2014.12.1949

173. Costa J, Silva I, Vicente AA, Oliveira M, Mafra I. Pistachio Nut Allergy: An Updated Overview. Crit Rev Food Sci Nutr (2019) 59:546-62. doi: 10.1080/ 10408398.2017.1379947

174. Flückiger S, Scapozza L, Mayer C, Blaser K, Folkers G, Crameri R. Immunological and Structural Analysis of IgE-Mediated Cross-Reactivity Between Manganese Superoxide Dismutases. Int Arch Allergy Immunol (2002) 128:292-303. doi: 10.1159/000063862

175. Hasegawa M, Inomata N, Yamazaki H, Morita A, Kirino M, Ikezawa Z. Clinical Features of Four Cases With Cashew Nut Allergy and CrossReactivity Between Cashew Nut and Pistachio. Allergol Int (2009) 58:20915. doi: 10.2332/allergolint.08-OA-0010

176. Salcedo G, Sánchez-Monge R, Barber D, Díaz-Perales A. Plant non-Specific Lipid Transfer Proteins: An Interface Between Plant Defence and Human Allergy. Biochim Biophys Acta (2007) 1771:781-91. doi: 10.1016/ j.bbalip.2007.01.001

177. Zuidmeer L, van Ree R. Lipid Transfer Protein Allergy: Primary Food Allergy or Pollen/Food Syndrome in Some Cases. Curr Opin Allergy Clin Immunol (2007) 7:269-73. doi: 10.1097/ACI.0b013e32814a5401

178. Mayer C, Appenzeller U, Seelbach H, Achatz G, Oberkofler H, Breitenbach $\mathrm{M}$, et al. Humoral and Cell-Mediated Autoimmune Reactions to Human Acidic Ribosomal P2 Protein in Individuals Sensitized to Aspergillus Fumigatus P2 Protein. J Exp Med (1999) 189:1507-12. doi: 10.1084/ jem.189.9.1507

179. Roux KH, Teuber SS, Robotham JM, Sathe SK. Detection and Stability of the Major Almond Allergen in Foods. J Agric Food Chem (2001) 49:2131-6. doi: 10.1021/jf001307k

180. Venkatachalam M, Teuber SS, Roux KH, Sathe SK. Effects of Roasting, Blanching, Autoclaving, and Microwave Heating on Antigenicity of Almond (Prunus Dulcis L.) Proteins. J Agric Food Chem (2002) 50:3544-8. doi: $10.1021 / \mathrm{jf} 020012 \mathrm{z}$

181. Rayes H, Raza AA, Williams A, Matthews S, Arshad SH. Specific IgE to Recombinant Protein (Ber E 1) for the Diagnosis of Brazil Nut Allergy. Clin Exp Allergy (2016) 46:654-6. doi: 10.1111/cea.12693

182. Sutherland MF, O’Hehir RE, Czarny D, Suphioglu C. Macadamia Nut Anaphylaxis: Demonstration of Specific IgE Reactivity and Partial CrossReactivity With Hazelnut. J Allergy Clin Immunol (1999) 104:889-90. doi: 10.1016/S0091-6749(99)70304-0

183. Herbst RA, Wahl R, Frosch PJ. Specific IgE Reactivity and Identification of Potential Allergens in Macadamia Allergy. J Eur Acad Dermatol Venereol (2010) 24:1361-3. doi: 10.1111/j.1468-3083.2010.03642.x

184. Ehlers AM, Rohwer S, Otten HG, Brix B, Le TM, Suer W, et al. IgE-Binding to Vicilin-Like Antimicrobial Peptides is Associated With Systemic Reactions to Macadamia Nut. Clin Transl Allergy (2020) 10:55. doi: 10.1186/s13601-020-00364-5

185. Knott E, Gürer CK, Ellwanger J, Ring J, Darsow U. Macadamia Nut Allergy. J Eur Acad Dermatol Venereol (2008) 22:1394-5. doi: 10.1111/j.14683083.2008.02657.x

186. Ekbote A, Hayman G, Bansal A. Macadamia Nut Allergy: Potentially Misleading Specific IgE Results. Allergy (2010) 65:1345. doi: 10.1111/ j.1398-9995.2010.02354.x

187. van Hage M, Hamsten C, Valenta R. ImmunoCAP Assays: Pros and Cons in Allergology. J Allergy Clin Immunol (2017) 140:974-7. doi: 10.1016/ j.jaci.2017.05.008
188. Bindslev-Jensen C, Ballmer-Weber BK, Bengtsson U, Blanco C, Ebner C, Hourihane J, et al. Standardization of Food Challenges in Patients With Immediate Reactions to Foods-Position Paper From the European Academy of Allergology and Clinical Immunology. Allergy (2004) 59:690-7. doi: 10.1111/j.1398-9995.2004.00466.x

189. Sampson HA, Gerth van Wijk R, Bindslev-Jensen C, Sicherer S, Teuber SS, Burks AW, et al. Standardizing Double-Blind, Placebo-Controlled Oral Food Challenges: American Academy of Allergy, Asthma \& ImmunologyEuropean Academy of Allergy and Clinical Immunology PRACTALL Consensus Report. J Allergy Clin Immunol (2012) 130:1260-74. doi: 10.1016/j.jaci.2012.10.017

190. Vazquez-Ortiz M, Ludman S, Aston A, Noimark L, Turner PJ. Lip Dose Challenges in Food Allergy: Current Practice and Diagnostic Utility in the United Kingdom. J Allergy Clin Immunol Pract (2019) 7:2770-2774.e3. doi: 10.1016/j.jaip.2019.04.037

191. Ansotegui IJ, Melioli G, Canonica GW, Caraballo L, Villa E, Ebisawa M, et al. IgE Allergy Diagnostics and Other Relevant Tests in Allergy, a World Allergy Organization Position Paper. World Allergy Organ J (2020) 13:100080. doi: 10.1016/j.waojou.2019.100080

192. Campana R, Moritz K, Marth K, Neubauer A, Huber H, Henning R, et al. Frequent Occurrence of $\mathrm{T}$ Cell-Mediated Late Reactions Revealed by Atopy Patch Testing With Hypoallergenic Rbet V 1 Fragments. J Allergy Clin Immunol (2016) 137:601-609.e8. doi: 10.1016/j.jaci.2015.08.042

193. Valenta R, Karaulov A, Niederberger V, Zhernov Y, Elisyutina O, Campana $\mathrm{R}$, et al. Allergen Extracts for In Vivo Diagnosis and Treatment of Allergy: Is There a Future? J Allergy Clin Immunol Pract (2018) 6:1845-1855.e2. doi: 10.1016/j.jaip.2018.08.032

194. Zivanovic M, Atanasković-Marković M, Medjo B, Gavrović-Jankulović M, Smiljanić K, Tmušić V, et al. Evaluation of Food Allergy in Children by Skin Prick Tests With Commercial Extracts and Fresh Foods, Specific IgE and, Open Oral Food Challenge-Our Five Years Experience in Food Allergy Work-Up. Iran J Allergy Asthma Immunol (2017) 16:127-32.

195. Rancé F, Juchet A, Brémont F, Dutau G. Correlations Between Skin Prick Tests Using Commercial Extracts and Fresh Foods, Specific IgE, and Food Challenges. Allergy (1997) 52:1031-5. doi: 10.1111/j.1398-9995. 1997.tb02427.x

196. Cetinkaya PG, Karaguzel D, Esenboğa S, Sahiner UM, Soyer O, Buyuktiryaki B, et al. Pistachio and Cashew Nut Allergy in Childhood: Predictive Factors Towards Development of a Decision Tree. Asian Pac J Allergy Immunol (2021) 39:53-61. doi: 10.12932/AP-281018-0429

197. Valenta R, Lidholm J, Niederberger V, Hayek B, Kraft D, Grönlund H. The Recombinant Allergen-Based Concept of Component-Resolved Diagnostics and Immunotherapy (CRD and CRIT). Clin Exp Allergy (1999) 29:896-904. doi: 10.1046/j.1365-2222.1999.00653.x

198. Dang TD, Tang M, Choo S, Licciardi PV, Koplin JJ, Martin PE, et al. Increasing the Accuracy of Peanut Allergy Diagnosis by Using Ara H 2. J Allergy Clin Immunol (2012) 129:1056-63. doi: 10.1016/j.jaci.2012.01.056

199. Klemans RJ, Broekman HC, Knol EF, Bruijnzeel-Koomen CA, Otten HG, Pasmans SG, et al. Ara H 2 is the Best Predictor for Peanut Allergy in Adults. J Allergy Clin Immunol Pract (2013) 1:632-8.e1. doi: 10.1016/j.jaip. 2013.07.014

200. Klemans RJ, Otte D, Knol M, Knol EF, Meijer Y, Gmelig-Meyling FH, et al. The Diagnostic Value of Specific IgE to Ara H 2 to Predict Peanut Allergy in Children is Comparable to a Validated and Updated Diagnostic Prediction Model. J Allergy Clin Immunol (2013) 131:157-63. doi: 10.1016/ j.jaci.2012.08.010

201. Lieberman JA, Glaumann S, Batelson S, Borres MP, Sampson HA, Nilsson C. The Utility of Peanut Components in the Diagnosis of IgE-Mediated Peanut Allergy Among Distinct Populations. J Allergy Clin Immunol Pract (2013) 1:75-82. doi: 10.1016/j.jaip.2012.11.002

202. Beyer K, Grabenhenrich L, Härtl M, Beder A, Kalb B, Ziegert M, et al. Predictive Values of Component-Specific IgE for the Outcome of Peanut and Hazelnut Food Challenges in Children. Allergy (2015) 70:90-8. doi: 10.1111/ all. 12530

203. Inoue $\mathrm{Y}$, Sato S, Takahashi K, Yanagida N, Yamamoto H, Shimizu N, et al. Component-Resolved Diagnostics can be Useful for Identifying Hazelnut Allergy in Japanese Children. Allergol Int (2020) 69:239-45. doi: 10.1016/ j.alit.2019.10.001 
204. Lange L, Lasota L, Finger A, Vlajnic D, Büsing S, Meister J, et al. Ana O 3Specific IgE is a Good Predictor for Clinically Relevant Cashew Allergy in Children. Allergy (2017) 72:598-603. doi: 10.1111/all.13050

205. van der Valk JP, Gerth van Wijk R, Vergouwe Y, Steyerberg EW, Reitsma M, Wichers HJ, et al. Sige Ana O 1, 2 and 3 Accurately Distinguish Tolerant From Allergic Children Sensitized to Cashew Nuts. Clin Exp Allergy (2017) 47:113-20. doi: 10.1111/cea.12794

206. Sato S, Movérare R, Ohya Y, Ito K, Nagao M, Borres MP, et al. Ana O 3Specific IgE is a Predictive Marker for Cashew Oral Food Challenge Failure. J Allergy Clin Immunol Pract (2019) 7:2909-2911.e4. doi: 10.1016/ j.jaip.2019.04.049

207. Sato S, Yamamoto M, Yanagida N, Ito K, Ohya Y, Imai T, et al. Jug R 1 Sensitization is Important in Walnut-Allergic Children and Youth. J Allergy Clin Immunol Pract (2017) 5:1784-1786.e1. doi: 10.1016/j.jaip.2017.04.025

208. Karsonova A, Riabova K, Villazala-Merino S, Campana R, Niederberger V, Eckl-Dorna J, et al. Highly Sensitive ELISA-Based Assay for Quantification of Allergen-Specific IgE Antibody Levels. Allergy (2020) 75:2668-70. doi: $10.1111 /$ all.14325

209. Huang HJ, Campana R, Akinfenwa O, Curin M, Sarzsinszky E, Karsonova A, et al. Microarray-Based Allergy Diagnosis: Quo Vadis? Front Immunol (2020) 11:594978. doi: 10.3389/fimmu.2020.594978

210. Hiller R, Laffer S, Harwanegg C, Huber M, Schmidt WM, Twardosz A, et al. Microarrayed Allergen Molecules: Diagnostic Gatekeepers for Allergy Treatment. FASEB J (2002) 16:414-6. doi: 10.1096/fj.01-0711fje

211. Hoang JA, Celik A, Lupinek C, Valenta R, Duan L, Dai R, et al. Modeling the Conversion Between Specific IgE Test Platforms for Nut Allergens in Children and Adolescents. Allergy (2020) 76:831-41. doi: 10.1111/all.14529

212. Garib V, Rigler E, Gastager F, Campana R, Dorofeeva Y, Gattinger P, et al. Determination of IgE and IgG Reactivity to More Than 170 Allergen Molecules in Paper-Dried Blood Spots. J Allergy Clin Immunol (2019) 143:437-40. doi: 10.1016/j.jaci.2018.08.047

213. Dubiela P, Dölle-Bierke S, Aurich S, Worm M, Hoffmann-Sommergruber K. Component-Resolved Diagnosis in Adult Patients With Food-Dependent Anaphylaxis. World Allergy Organ J (2021) 14:100530. doi: 10.1016/ j.waojou.2021.100530

214. Lichtenstein LM, Osler AG. Studies on the Mechanisms of Hypersensitivity Phenomena. IX. Histamine Release From Human Leukocytes by Ragweed Pollen Antigen. J Exp Med (1964) 120:507-30. doi: 10.1084/jem.120.4.507

215. Valenta R, Sperr W, Ferreira F, Valent P, Sillaber C, Tejkl M, et al. Induction of Specific Histamine Release From Basophils With Purified Natural and Recombinant Birch Pollen Allergens. J Allergy Clin Immunol (1993) 91:8897. doi: 10.1016/0091-6749(93)90300-5

216. Hoffmann HJ, Santos AF, Mayorga C, Nopp A, Eberlein B, Ferrer M, et al. The Clinical Utility of Basophil Activation Testing in Diagnosis and Monitoring of Allergic Disease. Allergy (2015) 70:1393-405. doi: 10.1111/ all. 12698

217. Caraballo L, Valenta R, Acevedo N, Zakzuk J. Are the Terms Major and Minor Allergens Useful for Precision Allergology? Front Immunol (2021) 12:651500. doi: 10.3389/fimmu.2021.651500

218. Mari A, Iacovacci P, Afferni C, Barletta B, Tinghino R, Di Felice G, et al. Specific IgE to Cross-Reactive Carbohydrate Determinants Strongly Affect the In Vitro Diagnosis of Allergic Diseases. J Allergy Clin Immunol (1999) 103:1005-11. doi: 10.1016/S0091-6749(99)70171-5

219. Gattinger P, Mittermann I, Lupinek C, Hofer G, Keller W, Bidovec Stojkovic $\mathrm{U}$, et al. Recombinant Glycoproteins Resembling Carbohydrate-Specific IgE Epitopes From Plants, Venoms and Mites. EBioMedicine (2019) 39:33-43. doi: 10.1016/j.ebiom.2018.12.002

220. Hemmer W, Altmann F, Holzweber F, Gruber C, Wantke F, Wöhrl S. ImmunoCAP Cellulose Displays Cross-Reactive Carbohydrate Determinant (CCD) Epitopes and can Cause False-Positive Test Results in Patients With High Anti-CCD IgE Antibody Levels. J Allergy Clin Immunol (2018) 141:372-381.e3. doi: 10.1016/j.jaci.2017.04.028

221. Altmann F. Coping With Cross-Reactive Carbohydrate Determinants in Allergy Diagnosis. Allergol J Int (2016) 25:98-105. doi: 10.1007/s40629-0160115-3

222. Cabauatan CR, Lupinek C, Scheiblhofer S, Weiss R, Focke-Tejkl M, Bhalla $\mathrm{PL}$, et al. Allergen Microarray Detects High Prevalence of Asymptomatic IgE
Sensitizations to Tropical Pollen-Derived Carbohydrates. J Allergy Clin Immunol (2014) 133:910-4.e5. doi: 10.1016/j.jaci.2013.10.004

223. Mari A. IgE to Cross-Reactive Carbohydrate Determinants: Analysis of the Distribution and Appraisal of the In Vivo and In Vitro Reactivity. Int Arch Allergy Immunol (2002) 129:286-95. doi: 10.1159/000067591

224. van der Veen MJ, van Ree R, Aalberse RC, Akkerdaas J, Koppelman SJ, Jansen HM, et al. Poor Biologic Activity of Cross-Reactive IgE Directed to Carbohydrate Determinants of Glycoproteins. J Allergy Clin Immunol (1997) 100:327-34. doi: 10.1016/S0091-6749(97)70245-8

225. Hauswirth AW, Natter S, Ghannadan M, Majlesi Y, Schernthaner GH, Sperr WR, et al. Recombinant Allergens Promote Expression of CD203c on Basophils in Sensitized Individuals. J Allergy Clin Immunol (2002) 110:102-9. doi: 10.1067/mai.2002.125257

226. Lötzsch B, Dölle S, Vieths S, Worm M. Exploratory Analysis of CD63 and CD203c Expression in Basophils From Hazelnut Sensitized and Allergic Individuals. Clin Transl Allergy (2016) 6:45. doi: 10.1186/s13601-016-0134-7

227. Kaul S, Lüttkopf D, Kastner B, Vogel L, Höltz G, Vieths S, et al. Mediator Release Assays Based on Human or Murine Immunoglobulin E in Allergen Standardization. Clin Exp Allergy (2007) 37:141-50. doi: 10.1111/j.13652222.2006.02618.x

228. Glaumann S, Nopp A, Johansson SG, Rudengren M, Borres MP, Nilsson C. Basophil Allergen Threshold Sensitivity, CD-Sens, IgE-Sensitization and DBPCFC in Peanut-Sensitized Children. Allergy (2012) 67:242-7. doi: 10.1111/j.1398-9995.2011.02754.x

229. Duan L, Celik A, Hoang JA, Schmidthaler K, So D, Yin X, et al. Basophil Activation Test Shows High Accuracy in the Diagnosis of Peanut and Tree Nut Allergy: The Markers of Nut Allergy Study. Allergy (2021) 76:1800-12. doi: $10.1111 /$ all.14695

230. Patil SU, Steinbrecher J, Calatroni A, Smith N, Ma A, Ruiter B, et al. Early Decrease in Basophil Sensitivity to Ara H 2 Precedes Sustained Unresponsiveness After Peanut Oral Immunotherapy. J Allergy Clin Immunol (2019) 144:1310-1319.e4. doi: 10.1016/j.jaci.2019.07.028

231. Orgel K, Burk C, Smeekens J, Suber J, Hardy L, Guo R, et al. Blocking Antibodies Induced by Peanut Oral and Sublingual Immunotherapy Suppress Basophil Activation and are Associated With Sustained Unresponsiveness. Clin Exp Allergy (2019) 49:461-70. doi: 10.1111/cea.13305

232. de Silva D, Geromi M, Panesar SS, Muraro A, Werfel T, HoffmannSommergruber $\mathrm{K}$, et al. Acute and Long-Term Management of Food Allergy: Systematic Review. Allergy (2014) 69:159-67. doi: 10.1111/all.12314

233. Larché M, Akdis CA, Valenta R. Immunological Mechanisms of AllergenSpecific Immunotherapy. Nat Rev Immunol (2006) 6:761-71. doi: 10.1038/ nri1934

234. Shamji MH, Layhadi JA, Sharif H, Penagos M, Durham SR. Immunological Responses and Biomarkers for Allergen-Specific Immunotherapy Against Inhaled Allergens. J Allergy Clin Immunol Pract (2021) 9:1769-78. doi: 10.1016/j.jaip.2021.03.029

235. Dorofeeva Y, Shilovs.kiy I, Tulaeva I, Focke-Tejkl M, Flicker S, Kudlay D, et al. Past, Present, and Future of Allergen Immunotherapy Vaccines. Allergy (2020) 76:131-49. doi: 10.1111/all.14300

236. Shamji MH, Valenta R, Jardetzky T, Verhasselt V, Durham SR, Würtzen PA, et al. The Role of Allergen-Specific IgE, IgG and IgA in Allergic Disease. Allergy (2021). doi: 10.1111/all.14908

237. Niederberger V, Neubauer A, Gevaert P, Zidarn M, Worm M, Aberer W, et al. Safety and Efficacy of Immunotherapy With the Recombinant B-Cell Epitope-Based Grass Pollen Vaccine BM32. J Allergy Clin Immunol (2018) 142:497-509.e9. doi: 10.1016/j.jaci.2017.09.052

238. Eckl-Dorna J, Weber M, Stanek V, Linhart B, Ristl R, Waltl EE, et al. Two Years of Treatment With the Recombinant Grass Pollen Allergy Vaccine BM32 Induces a Continuously Increasing Allergen-Specific IgG4 Response. EBioMedicine (2019) 50:421-32. doi: 10.1016/j.ebiom.2019.11.006

239. Orengo JM, Radin AR, Kamat V, Badithe A, Ben LH, Bennett BL, et al. Treating Cat Allergy With Monoclonal IgG Antibodies That Bind Allergen and Prevent IgE Engagement. Nat Commun (2018) 9:1421. doi: 10.1038/ s41467-018-03636-8

240. Gevaert P, De Craemer J, De Ruyck N, Rottey S, de Hoon J, Hellings PW, et al. Novel Antibody Cocktail Targeting Bet V 1 Rapidly and Sustainably Treats Birch Allergy Symptoms in a Phase 1 Study. J Allergy Clin Immunol (2021) 11:S0091-6749(21)00904-0. doi: 10.1016/j.jaci.2021.05.039 
241. Shamji MH, Singh I, Layhadi JA, Ito C, Karamani A, Kouser L, et al. Passive Prophylactic Administration With a Single Dose of Anti-Fel D 1 Monoclonal Antibodies REGN1908-1909 in Cat Allergen-Induced Allergic Rhinitis: A Randomized, Double-Blind, Placebo Controlled Trial. Am J Respir Crit Care Med (2021) 204:23-33. doi: 10.1164/rccm.202011-4107OC

242. Passalacqua G, Bagnasco D, Canonica GW. 30 Years of Sublingual Immunotherapy. Allergy (2020) 75:1107-20. doi: 10.1111/all.14113

243. Kiel MA, Röder E, Gerth van Wijk R, Al MJ, Hop WC, Rutten-van Mölken MP. Real-Life Compliance and Persistence Among Users of Subcutaneous and Sublingual Allergen Immunotherapy. J Allergy Clin Immunol (2013) 132:353-60.e2. doi: 10.1016/j.jaci.2013.03.013

244. Oppenheimer J, Nelson H, Bock S, Christensen F, Leung D. Treatment of Peanut Allergy With Rush Immunotherapy. J Allergy Clin Immunol (1992) 90:256-62. doi: 10.1016/0091-6749(92)90080-1

245. Nelson H, Lahr J, Rule R, Bock A, Leung D. Treatment of Anaphylactic Sensitivity to Peanuts by Immunotherapy With Injections of Aqueous Peanut Extract1. J Allergy Clin Immunol (1997) 99:744-51. doi: 10.1016/ S0091-6749(97)80006-1

246. Cooper PJ, Darbyshire J, Nunn AJ, Warner JO. A Controlled Trial of Oral Hyposensitization in Pollen Asthma and Rhinitis in Children. Clin Allergy (1984) 14:541-50. doi: 10.1111/j.1365-2222.1984.tb02242.x

247. Taudorf E, Laursen LC, Djurup R, Kappelgaard E, Pedersen CT, Søborg M, et al. Oral Administration of Grass Pollen to Hay Fever Patients. An Efficacy Study in Oral Hyposensitization. Allergy (1985) 40:321-35. doi: 10.1111/ j.1398-9995.1985.tb00243.x

248. Möller C, Dreborg S, Lanner A, Björkstén B. Oral Immunotherapy of Children With Rhinoconjunctivitis Due to Birch Pollen Allergy. A Double Blind Study. Allergy (1986) 41:271-9. doi: 10.1111/j.1398-9995. 1986.tb02028.x

249. Jones SM, Pons L, Roberts JL, Scurlock AM, Perry TT, Kulis M, et al. Clinical Efficacy and Immune Regulation With Peanut Oral Immunotherapy. J Allergy Clin Immunol (2009) 124:292-30197. doi: 10.1016/j.jaci.2009.05.022

250. Blumchen K, Ulbricht H, Staden U, Dobberstein K, Beschorner J, de Oliveira LC, et al. Oral Peanut Immunotherapy in Children With Peanut Anaphylaxis. J Allergy Clin Immunol (2010) 126:83-91.e1. doi: 10.1016/ j.jaci.2010.04.030

251. Varshney P, Jones SM, Scurlock AM, Perry TT, Kemper A, Steele P, et al. A Randomized Controlled Study of Peanut Oral Immunotherapy: Clinical Desensitization and Modulation of the Allergic Response. J Allergy Clin Immunol (2011) 127:654-60. doi: 10.1016/j.jaci.2010.12.1111

252. Anagnostou K, Clark A, King Y, Islam S, Deighton J, Ewan P. Efficacy and Safety of High-Dose Peanut Oral Immunotherapy With Factors Predicting Outcome. Clin Exp Allergy (2011) 41:1273-81. doi: 10.1111/j.13652222.2011.03699.x

253. Anagnostou K, Islam S, King Y, Foley L, Pasea L, Bond S, et al. Assessing the Efficacy of Oral Immunotherapy for the Desensitisation of Peanut Allergy in Children (STOP II): A Phase 2 Randomised Controlled Trial. Lancet (2014) 383:1297-304. doi: 10.1016/S0140-6736(13)62301-6

254. Vickery BP, Scurlock AM, Kulis M, Steele PH, Kamilaris J, Berglund JP, et al. Sustained Unresponsiveness to Peanut in Subjects Who Have Completed Peanut Oral Immunotherapy. J Allergy Clin Immunol (2014) 133:468-475.e6. doi: 10.1016/j.jaci.2013.11.007

255. Narisety SD, Frischmeyer-Guerrerio PA, Keet CA, Gorelik M, Schroeder J, Hamilton RG, et al. A Randomized, Double-Blind, Placebo-Controlled Pilot Study of Sublingual Versus Oral Immunotherapy for the Treatment of Peanut Allergy. J Allergy Clin Immunol (2015) 135:1275-82. doi: 10.1016/ j.jaci.2014.11.005

256. Bird JA, Feldman M, Arneson A, Dougherty I, Brown LS, Burk CM, et al. Modified Peanut Oral Immunotherapy Protocol Safely and Effectively Induces Desensitization. J Allergy Clin Immunol Pract (2015) 3:433-5. doi: 10.1016/j.jaip.2014.11.020

257. Tang ML, Ponsonby AL, Orsini F, Tey D, Robinson M, Su EL, et al. Administration of a Probiotic With Peanut Oral Immunotherapy: A Randomized Trial. J Allergy Clin Immunol (2015) 135:737-44.e8. doi: 10.1016/j.jaci.2014.11.034

258. Kukkonen AK, Uotila R, Malmberg LP, Pelkonen AS, Mäkelä MJ. DoubleBlind Placebo-Controlled Challenge Showed That Peanut Oral Immunotherapy was Effective for Severe Allergy Without Negative Effects on Airway Inflammation. Acta Paediatr (2017) 106:274-81. doi: 10.1111/ apa.13668

259. Vickery BP, Berglund JP, Burk CM, Fine JP, Kim EH, Kim JI, et al. Early Oral Immunotherapy in Peanut-Allergic Preschool Children is Safe and Highly Effective. J Allergy Clin Immunol (2017) 139:173-181.e8. doi: 10.1016/ j.jaci.2016.05.027

260. Bird JA, Spergel JM, Jones SM, Rachid R, Assa'ad AH, Wang J, et al. Efficacy and Safety of AR101 in Oral Immunotherapy for Peanut Allergy: Results of ARC001, a Randomized, Double-Blind, Placebo-Controlled Phase 2 Clinical Trial. J Allergy Clin Immunol Pract (2018) 6:476-485.e3. doi: 10.1016/ j.jaip.2017.09.016

261. PALISADE Group, Vickery BP, Vereda A, Casale TB, Beyer K, Du Toit G, et al. AR101 Oral Immunotherapy for Peanut Allergy. N Engl J Med (2018) 379:1991-2001. doi: 10.1056/NEJMoa1812856

262. Nagakura KI, Yanagida N, Sato S, Nishino M, Asaumi T, Ogura K, et al. Low-Dose Oral Immunotherapy for Children With Anaphylactic Peanut Allergy in Japan. Pediatr Allergy Immunol (2018) 29:512-8. doi: 10.1111/ pai. 12898

263. Fauquert JL, Michaud E, Pereira B, Bernard L, Gourdon-Dubois N, Rouzaire PO, et al. Peanut Gastrointestinal Delivery Oral Immunotherapy in Adolescents: Results of the Build-Up Phase of a Randomized, Double-Blind, Placebo-Controlled Trial (PITA Study). Clin Exp Allergy (2018) 48:862-74. doi: $10.1111 /$ cea. 13148

264. Blumchen K, Trendelenburg V, Ahrens F, Gruebl A, Hamelmann E, Hansen G, et al. Efficacy, Safety, and Quality of Life in a Multicenter, Randomized, Placebo-Controlled Trial of Low-Dose Peanut Oral Immunotherapy in Children With Peanut Allergy. J Allergy Clin Immunol Pract (2019) 7:479491.e10. doi: 10.1016/j.jaip.2018.10.048

265. Wasserman RL, Hague AR, Pence DM, Sugerman RW, Silvers SK, Rolen JG, et al. Real-World Experience With Peanut Oral Immunotherapy: Lessons Learned From 270 Patients. J Allergy Clin Immunol Pract (2019) 7:418426.e4. doi: 10.1016/j.jaip.2018.05.023

266. Elizur A, Appel MY, Nachshon L, Levy MB, Epstein-Rigbi N, Pontoppidan B, et al. Walnut Oral Immunotherapy for Desensitisation of Walnut and Additional Tree Nut Allergies (Nut CRACKER): A Single-Centre, Prospective Cohort Study. Lancet Child Adolesc Health (2019) 3:312-21. doi: 10.1016/S2352-4642(19)30029-X

267. Chinthrajah RS, Purington N, Andorf S, Long A, O'Laughlin KL, Lyu SC, et al. Sustained Outcomes in a Large Double-Blind, Placebo-Controlled, Randomized Phase 2 Study of Peanut Immunotherapy. Lancet (2019) 394:1437-49. doi: 10.1016/S0140-6736(19)31793-3

268. Moraly T, Pelletier de Chambure D, Verdun S, Preda C, Seynave M, Vilain AC, et al. Oral Immunotherapy for Hazelnut Allergy: A Single-Center Retrospective Study on 100 Patients. J Allergy Clin Immunol Pract (2020) 8:704-709.e4. doi: 10.1016/j.jaip.2019.10.045

269. Hourihane JO, Beyer K, Abbas A, Fernández-Rivas M, Turner PJ, Blumchen $\mathrm{K}$, et al. Efficacy and Safety of Oral Immunotherapy With AR101 in European Children With a Peanut Allergy (ARTEMIS): A Multicentre, Double-Blind, Randomised, Placebo-Controlled Phase 3 Trial. Lancet Child Adolesc Health (2020) 4:728-39. doi: 10.1016/S2352-4642(20)30234-0

270. Vickery BP, Vereda A, Nilsson C, Du Toit G, Shreffler WG, Burks AW, et al. Continuous and Daily Oral Immunotherapy for Peanut Allergy: Results From a 2-Year Open-Label Follow-on Study. J Allergy Clin Immunol Pract (2021) 9:1879-1889.e14. doi: 10.1016/j.jaip.2020.12.029

271. Enrique E, Pineda F, Malek T, Bartra J, Basagaña M, Tella R, et al. Sublingual Immunotherapy for Hazelnut Food Allergy: A Randomized, Double-Blind, Placebo-Controlled Study With a Standardized Hazelnut Extract. J Allergy Clin Immunol (2005) 116:1073-9. doi: 10.1016/j.jaci.2005.08.027

272. Kim EH, Bird JA, Kulis M, Laubach S, Pons L, Shreffler W, et al. Sublingual Immunotherapy for Peanut Allergy: Clinical and Immunologic Evidence of Desensitization. J Allergy Clin Immunol (2011) 127:640-646.e1. doi: 10.1016/ j.jaci.2010.12.1083

273. Fleischer DM, Burks AW, Vickery BP, Scurlock AM, Wood RA, Jones SM, et al. Sublingual Immunotherapy for Peanut Allergy: A Randomized, Double-Blind, Placebo-Controlled Multicenter Trial. J Allergy Clin Immunol (2013) 131:119-127.e7. doi: 10.1016/j.jaci.2012.11.011

274. Burks AW, Wood RA, Jones SM, Sicherer SH, Fleischer DM, Scurlock AM, et al. Sublingual Immunotherapy for Peanut Allergy: Long-Term Follow-Up 
of a Randomized Multicenter Trial. J Allergy Clin Immunol (2015) 135:12408. doi: 10.1016/j.jaci.2014.12.1917

275. Kim EH, Yang L, Ye P, Guo R, Li Q, Kulis MD, et al. Long-Term Sublingual Immunotherapy for Peanut Allergy in Children: Clinical and Immunologic Evidence of Desensitization. J Allergy Clin Immunol (2019) 144:13201326.e1. doi: 10.1016/j.jaci.2019.07.030

276. Jones SM, Sicherer SH, Burks AW, Leung DY, Lindblad RW, Dawson P, et al. Epicutaneous Immunotherapy for the Treatment of Peanut Allergy in Children and Young Adults. J Allergy Clin Immunol (2017) 139:12421252.e9. doi: 10.1016/j.jaci.2016.08.017

277. Sampson HA, Shreffler WG, Yang WH, Sussman GL, Brown-Whitehorn TF, Nadeau KC, et al. Effect of Varying Doses of Epicutaneous Immunotherapy vs. Placebo on Reaction to Peanut Protein Exposure Among Patients With Peanut Sensitivity: A Randomized Clinical Trial. JAMA (2017) 318:1798809. doi: 10.1001/jama.2017.16591

278. Fleischer DM, Greenhawt M, Sussman G, Bégin P, Nowak-Wegrzyn A, Petroni D, et al. Effect of Epicutaneous Immunotherapy vs. Placebo on Reaction to Peanut Protein Ingestion Among Children With Peanut Allergy: The PEPITES Randomized Clinical Trial. JAMA (2019) 321:946-55. doi: 10.1001/jama.2019.1113

279. Wood RA, Sicherer SH, Burks AW, Grishin A, Henning AK, Lindblad R, et al. A Phase 1 Study of Heat/Phenol-Killed, E. Coli-Encapsulated, Recombinant Modified Peanut Proteins Ara H 1, Ara H 2, and Ara H 3 (EMP-123) for the Treatment of Peanut Allergy. Allergy (2013) 68:803-8. doi: $10.1111 /$ all.12158

280. Andorf S, Purington N, Block WM, Long AJ, Tupa D, Brittain E, et al. AntiIgE Treatment With Oral Immunotherapy in Multifood Allergic Participants: A Double-Blind, Randomised, Controlled Trial. Lancet Gastroenterol Hepatol (2018) 3:85-94. doi: 10.1016/S2468-1253(17)30392-8

281. Berglund JP, Szczepanski N, Penumarti A, Beavers A, Kesselring J, Orgel K, et al. Preparation and Analysis of Peanut Flour Used in Oral Immunotherapy Clinical Trials. J Allergy Clin Immunol Pract (2017) 5:1098-104. doi: 10.1016/j.jaip.2016.11.034

282. Hofmann AM, Scurlock AM, Jones SM, Palmer KP, Lokhnygina Y, Steele $\mathrm{PH}$, et al. Safety of a Peanut Oral Immunotherapy Protocol in Children With Peanut Allergy. J Allergy Clin Immunol (2009) 124:286-91. doi: 10.1016/ j.jaci.2009.03.045

283. Schneider LC, Rachid R, LeBovidge J, Blood E, Mittal M, Umetsu DT. A Pilot Study of Omalizumab to Facilitate Rapid Oral Desensitization in High-Risk Peanut-Allergic Patients. J Allergy Clin Immunol (2013) 132:1368-74. doi: 10.1016/j.jaci.2013.09.046

284. MacGinnitie AJ, Rachid R, Gragg H, Little SV, Lakin P, Cianferoni A, et al. Omalizumab Facilitates Rapid Oral Desensitization for Peanut Allergy. J Allergy Clin Immunol (2017) 139:873-881.e8. doi: 10.1016/j.jaci. 2016.08.010

285. Yee CS, Albuhairi S, Noh E, El-Khoury K, Rezaei S, Abdel-Gadir A, et al. Long-Term Outcome of Peanut Oral Immunotherapy Facilitated Initially by Omalizumab. J Allergy Clin Immunol Pract (2019) 7:451-461.e7. doi: 10.1016/j.jaip.2018.09.015

286. Chu DK, Wood RA, French S, Fiocchi A, Jordana M, Waserman S, et al. Oral Immunotherapy for Peanut Allergy (PACE): A Systematic Review and MetaAnalysis of Efficacy and Safety. Lancet (2019) 393:2222-32. doi: 10.1016/ S0140-6736(19)30420-9

287. Eiwegger T, Anagnostou K, Arasi S, Bégin P, Ben-Shoshan M, Beyer K, et al. Conflicting Verdicts on Peanut Oral Immunotherapy From the Institute for Clinical and Economic Review and US Food and Drug Administration Advisory Committee: Where do We Go From Here? J Allergy Clin Immunol (2020) 145:1153-6. doi: 10.1016/j.jaci.2019.10.021

288. Senti G, Graf N, Haug S, Rüedi N, von Moos S, Sonderegger T, et al. Epicutaneous Allergen Administration as a Novel Method of AllergenSpecific Immunotherapy. J Allergy Clin Immunol (2009) 124:997-1002. doi: 10.1016/j.jaci.2009.07.019

289. Xiong L, Lin J, Luo Y, Chen W, Dai J. The Efficacy and Safety of Epicutaneous Immunotherapy for Allergic Diseases: A Systematic Review and Meta-Analysis. Int Arch Allergy Immunol (2020) 181:170-82. doi: $10.1159 / 000504366$

290. Pauli G, Larsen TH, Rak S, Horak F, Pastorello E, Valenta R, et al. Efficacy of Recombinant Birch Pollen Vaccine for the Treatment of Birch-Allergic
Rhinoconjunctivitis. J Allergy Clin Immunol (2008) 122:951-60. doi: 10.1016/j.jaci.2008.09.017

291. Niederberger V, Horak F, Vrtala S, Spitzauer S, Krauth MT, Valent P, et al. Vaccination With Genetically Engineered Allergens Prevents Progression of Allergic Disease. Proc Natl Acad Sci U.S.A. (2004) 101 Suppl 2:14677-82. doi: 10.1073/pnas.0404735101

292. Zieglmayer P, Focke-Tejkl M, Schmutz R, Lemell P, Zieglmayer R, Weber M, et al. Mechanisms, Safety and Efficacy of a B Cell Epitope-Based Vaccine for Immunotherapy of Grass Pollen Allergy. EBioMedicine (2016) 11:43-57. doi: 10.1016/j.ebiom.2016.08.022

293. Swoboda I, Bugajska-Schretter A, Verdino P, Keller W, Sperr WR, Valent P, et al. Recombinant Carp Parvalbumin, the Major Cross-Reactive Fish Allergen: A Tool for Diagnosis and Therapy of Fish Allergy. J Immunol (2002) 168:4576-84. doi: 10.4049/jimmunol.168.9.4576

294. Swoboda I, Bugajska-Schretter A, Linhart B, Verdino P, Keller W, Schulmeister U, et al. A Recombinant Hypoallergenic Parvalbumin Mutant for Immunotherapy of IgE-Mediated Fish Allergy. J Immunol (2007) 178:6290-6. doi: 10.4049/jimmunol.178.10.6290

295. Douladiris N, Linhart B, Swoboda I, Gstöttner A, Vassilopoulou E, Stolz F, et al. In Vivo Allergenic Activity of a Hypoallergenic Mutant of the Major Fish Allergen Cyp C 1 Evaluated by Means of Skin Testing. J Allergy Clin Immunol (2015) 136:493-5.e8. doi: 10.1016/j.jaci.2015.01.015

296. Zuidmeer-Jongejan L, Huber H, Swoboda I, Rigby N, Versteeg SA, Jensen BM, et al. Development of a Hypoallergenic Recombinant Parvalbumin for First-in-Man Subcutaneous Immunotherapy of Fish Allergy. Int Arch Allergy Immunol (2015) 166:41-51. doi: 10.1159/000371657

297. Zuidmeer-Jongejan L, Fernandez-Rivas M, Poulsen LK, Neubauer A, Asturias J, Blom L, et al. FAST: Towards Safe and Effective Subcutaneous Immunotherapy of Persistent Life-Threatening Food Allergies. Clin Transl Allergy (2012) 2:5. doi: 10.1186/2045-7022-2-5

298. King N, Helm R, Stanley JS, Vieths S, Lüttkopf D, Hatahet L, et al. Allergenic Characteristics of a Modified Peanut Allergen. Mol Nutr Food Res (2005) 49:963-71. doi: 10.1002/mnfr.200500073

299. Rabjohn P, West CM, Connaughton C, Sampson HA, Helm RM, Burks AW, et al. Modification of Peanut Allergen Ara H 3: Effects on IgE Binding and T Cell Stimulation. Int Arch Allergy Immunol (2002) 128:15-23. doi: 10.1159/ 000057999

300. Bannon GA, Cockrell G, Connaughton C, West CM, Helm R, Stanley JS, et al. Engineering, Characterization and In Vitro Efficacy of the Major Peanut Allergens for Use in Immunotherapy. Int Arch Allergy Immunol (2001) 124:70-2. doi: 10.1159/000053672

301. Bublin M, Kostadinova M, Radauer C, Varga EM, Hafner C, Schmidthaler K, et al. Engineering of Structural Variants of the Major Peanut Allergens Ara $\mathrm{H}$ 2 and Ara $\mathrm{H} 6$ for Allergen-Specific Immunotherapy. J Allergy Clin Immunol (2019) 143:1226-1229.e10. doi: 10.1016/j.jaci.2018.10.039

302. Mauro M, Russello M, Incorvaia C, Gazzola G, Frati F, Moingeon P, et al. Birch-Apple Syndrome Treated With Birch Pollen Immunotherapy. Int Arch Allergy Immunol (2011) 156:416-22. doi: 10.1159/000323909

303. Gadermaier E, Flicker S, Aberer W, Egger C, Reider N, Focke M, et al. Analysis of the Antibody Responses Induced by Subcutaneous Injection Immunotherapy With Birch and Fagales Pollen Extracts Adsorbed Onto Aluminum Hydroxide. Int Arch Allergy Immunol (2010) 151:17-27. doi: 10.1159/000232567

304. Marth K, Breyer I, Focke-Tejkl M, Blatt K, Shamji MH, Layhadi J, et al. A Nonallergenic Birch Pollen Allergy Vaccine Consisting of Hepatitis PreSfused Bet V 1 Peptides Focuses Blocking IgG Toward IgE Epitopes and Shifts Immune Responses to a Tolerogenic and Th1 Phenotype. J Immunol (2013) 190:3068-78. doi: 10.4049/jimmunol.1202441

305. Campana R, Vrtala S, Maderegger B, Jertschin P, Stegfellner G, Swoboda I, et al. Hypoallergenic Derivatives of the Major Birch Pollen Allergen Bet V 1 Obtained by Rational Sequence Reassembly. J Allergy Clin Immunol (2010) 126:1024-31. doi: 10.1016/j.jaci.2010.05.023

306. Hofer H, Asam C, Hauser M, Nagl B, Laimer J, Himly M, et al. Tackling Bet V 1 and Associated Food Allergies With a Single Hybrid Protein. J Allergy Clin Immunol (2017) 140:525-533.e10. doi: 10.1016/j.jaci.2016.09.055

307. Purohit A, Niederberger V, Kronqvist M, Horak F, Grönneberg R, Suck R, et al. Clinical Effects of Immunotherapy With Genetically Modified Recombinant Birch Pollen Bet V 1 Derivatives. Clin Exp Allergy (2008) 38:1514-25. doi: 10.1111/j.1365-2222.2008.03042.x 
308. Haselden BM, Kay AB, Larché M. Immunoglobulin E-Independent Major Histocompatibility Complex-Restricted T Cell Peptide Epitope-Induced Late Asthmatic Reactions. J Exp Med (1999) 189:1885-94. doi: 10.1084/ jem.189.12.1885

309. Valenta R, Campana R, Niederberger V. Recombinant Allergy Vaccines Based on Allergen-Derived B Cell Epitopes. Immunol Lett (2017) 189:19-26. doi: 10.1016/j.imlet.2017.04.015

310. Shamji MH, Kappen JH, Akdis M, Jensen-Jarolim E, Knol EF, Kleine-Tebbe J, et al. Biomarkers for Monitoring Clinical Efficacy of Allergen Immunotherapy for Allergic Rhinoconjunctivitis and Allergic Asthma: An EAACI Position Paper. Allergy (2017) 72:1156-73. doi: 10.1111/all.13138

Conflict of Interest: RV has received research grants from HVD Life Science, Vienna Austria, Viravaxx, Vienna, Austria and Worg Pharmaceuticals, Hangzhou, China and serves as a consultant for Viravaxx and Worg. $\mathrm{MvH}$ has received personal fees from Thermo Fisher Scientific, Sweden, and Hycor Biomedical LLC, CA, US., outside the submitted work.
The remaining authors declare that the research was conducted in the absence of any commercial or financial relationships that could be construed as a potential conflict of interest.

Publisher's Note: All claims expressed in this article are solely those of the authors and do not necessarily represent those of their affiliated organizations, or those of the publisher, the editors and the reviewers. Any product that may be evaluated in this article, or claim that may be made by its manufacturer, is not guaranteed or endorsed by the publisher.

Copyright (c) 2021 Fuhrmann, Huang, Akarsu, Shilovskiy, Elisyutina, Khaitov, van Hage, Linhart, Focke-Tejkl, Valenta and Sekerel. This is an open-access article distributed under the terms of the Creative Commons Attribution License (CC BY). The use, distribution or reproduction in other forums is permitted, provided the original author(s) and the copyright owner(s) are credited and that the original publication in this journal is cited, in accordance with accepted academic practice. No use, distribution or reproduction is permitted which does not comply with these terms. 